INSTITUTO DE PESQUISAS E NUCLEARES

Autarquia associada à Universidade de São Paulo

\title{
CULTIVO E IRRADIAÇÃO DE FIBROBLASTOS HUMANOS EM MEIO ENRIQUECIDO COM LISADO DE PLAQUETAS PARA OBTENÇÃO DE CAMADA DE SUSTENTAÇÃO EM CULTURA DE CÉLULAS DA EPIDERME
}

DANIELE YOSHITO

Dissertação apresentada como parte dos requisitos para obtenção do Grau de Mestre em Ciências na Área de Tecnologia Nuclear - Aplicações

Orientadora:

Dra. Monica Beatriz Mathor

São Paulo 
Ao meu pai Cedi Yoshito, à minha irmã Beatriz Yoshito e à minha avó Emiko Yoshito pelo apoio oferecido em todos os momentos de minha vida e principalmente neste 


\section{Agradecimentos}

À Dra. Monica Beatriz Mathor, pela orientação, dedicação, amizade e principalmente pela confiança no meu trabalho.

À Comissão Nacional de Energia Nuclear (CNEN) pelo apoio financeiro para a realização deste trabalho

Aos integrantes da Comissão de Pós Graduação do IPEN, pelo empenho e dedicação para oferecer todas as condições necessárias aos alunos pósgraduandos.

Ao Centro de Tecnologia das Radiações (CTR) e ao Centro de Biotecnologia (CB), pelo acolhimento e por permitir a utilização das instalações e propiciar o bom desenvolvimento do trabalho.

Ao Dr. César Isaac, pela constante ajuda e atenção, e por manter sempre abertas as portas do Laboratório de Investigação Média LIN-04 da Faculdade de Medicina da USP.

À Dra. Andrea Cecília Dórion Rodas, pelos ensinamentos e sugestões dadas durante a avaliação do seminário e área e também pela amizade.

À Silvana Altran, pela importante ajuda durante a realização deste trabalho e principalmente pela amizade.

À minhas queridas amigas Stefany Santin, Bianca Sufi e Natália Mencacci pela incansável ajuda para realização deste trabalho e principalmente pelo apoio e amizade.

À minha prezada amiga Fátima Klingbeil, pelos ensinamentos na cultura celular e pela constante ajuda desde minha iniciação científica.

Aos meus companheiros de laboratório: Patrícia Lopes, Antônio Carlos Martinho Júnior, Fernando Augusto Soares, Fabiana de Andrade e Rodrigo Mosca, pelo apoio e amizade.

À minha amiga Janaina Batista, "minha mãe", pela amizade e pelos conselhos nos momentos mais difíceis.

Aos meus queridos amigos Tiago Luiz de Almeida e Priscila Caproni pela grande ajuda, carinho e amizade.

Aos engenheiros Elizabeth Somessari e Carlos Gaia, pela irradiação das células e também pela grande ajuda e amizade. 
Aos amigos do CB: Karina Corleto, Rosa Chura-Chambi, Fernanda Calvo Thiago Malpighi, Natália Malavasi, Rodrigo Queiroz, Alberto Alves, Kelly Nunes, Adriana Miranda e Cinthia Zanini, pelo apoio e amizade.

Aos amigos do CTR: Yasko Kodama, Sammir Somessari, Eduardo Moura, Laércio Carvalho e Paulo de Souza Santos.

Às minhas queridas amigas de faculdade: Andrea Nastri, Luciane Teixeira, Juliana Carneiro e Tatiane Alves, pelo carinho e pela amizade.

À Dra. Olga Zazuco Higa, por permitir a utilização do equipamento espectrofotômetro com multidetetores.

Ao Dr. Cyrillo Cavalheiro Filho, da Fundação Zerbini - Instituto do Coração HCFMUSP, pela generosa doação das bolsas de concentrado de plaquetas.

Ao Dr. Diógenes de Souza Bido pelas análises estatísticas.

Aos secretários: Rute Batista, Marcos Cardoso da Silva, Cláudia R. Nolla e Arlete Correia, pela constante ajuda. 


\title{
CULTIVO E IRRADIAÇÃO DE FIBROBLASTOS HUMANOS EM MEIO ENRIQUECIDO COM LISADO DE PLAQUETAS PARA OBTENÇÃO DE CAMADA DE SUSTENTAÇÃO EM CULTURA DE CÉLULAS DA EPIDERME
}

\author{
Daniele Yoshito
}

\begin{abstract}
RESUMO
Por mais de 30 anos, a utilização do meio de cultura, enriquecido com soro bovino, e de fibroblastos murinos, com a taxa de proliferação controlada por irradiação ou por ação de drogas anti-cancerígenas, vem desempenhando com sucesso o seu papel de auxiliar no desenvolvimento dos queratinócitos em cultura, para fins clínicos. Porém, atualmente há uma preocupação crescente acerca da possibilidade de transmissão de príons e virose animais, aos pacientes transplantados. Levando em conta esta preocupação, o presente trabalho tem como objetivo cultivar fibroblastos humanos em meio enriquecido com lisado de plaquetas humanas e determinar a dose de irradiação dessas células, para obtenção da camada de sustentação na cultura de células da epiderme. Para realização do objetivo proposto, padronizamos a lise das plaquetas, utilizamos este lisado para cultivar os fibroblastos humanos e verificamos a dose de irradiação suficiente para inibir sua duplicação. Queratinócitos humanos foram cultivados nestas camadas de sustentação, em meio de cultura suplementado com o lisado. Com os resultados obtidos concluímos que o lisado de plaquetas a $10 \%$ promoveu uma melhor adesão e proliferação dos fibroblastos humanos e em todas as doses testadas ( 60 a 300 Gy), estes tiveram as suas atividades mitóticas inativadas pela radiação ionizante, sendo que as camadas de sustentação obtidas com doses de 70 a 150 Gy foram as que proporcionaram o melhor desenvolvimento dos queratinócitos em meio contendo $2,5 \%$ de lisado de plaquetas humanas. Portanto, foi possível padronizar, tanto o cultivo dos fibroblastos humanos, quanto sua inativação para utilização como camada de sustentação na cultura de queratinócitos, de maneira a eliminar os componentes xenobióticos.
\end{abstract}




\title{
CULTIVATION AND IRRADIATION OF HUMAN FIBROBLASTS IN A MEDIUM ENRICHED WITH PLATELET LYSATE FOR OBTAINING FEEDER \\ LAYER IN EPIDERMAL CELL CULTURE
}

\section{Daniele Yoshito}

\begin{abstract}
For over 30 years, the use of culture medium, enriched with bovine serum, and murines fibroblasts, with the rate of proliferation controlled by irradiation or by share anticarcinogenic drugs, has been playing successfully its role in assisting in the development of keratinocytes in culture, for clinical purposes. However, currently there is a growing concern about the possibility of transmitting prions and animals viruses to transplanted patients. Taking into account this concern, the present work aims to cultivate human fibroblasts in a medium enriched with human platelets lysate and determine the irradiation dose of these cells, for obtaining feeder layer in epidermal cell culture. For carrying out the proposed objective, platelets lysis has standardized, this lysate was used for human fibroblasts cultivation and the irradiation dose enough to inhibit its duplication was evaluated. Human keratinocytes were cultivated in these feeder layers, in culture medium enriched with the lysate. With these results we conclude that the $10 \%$ platelets lysate promoted a better adhesion and proliferation of human fibroblasts and in all dose levels tested (60 to $300 \mathrm{~Gy}$ ), these had their mitotic activity inactivated by ionizing irradiation, being that the feeder layers obtained with doses from 70 to 150 Gy were those that provided the best development of keratinocytes in medium containing $2.5 \%$ of human platelet lysate. Therefore, it was possible to standardize both the cultivation of human fibroblasts as its inactivation for use as feeder layer in culture of keratinocytes, so as to eliminate xenobiotics components.
\end{abstract}




\section{SUMÁRIO}

Página

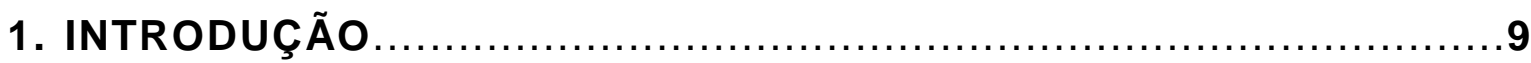

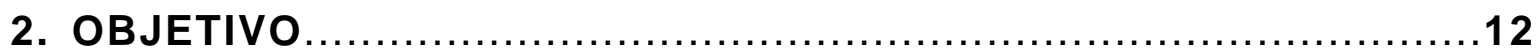

3. REVISÃO DA LITERATURA

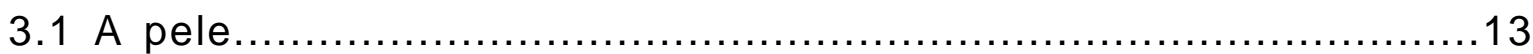

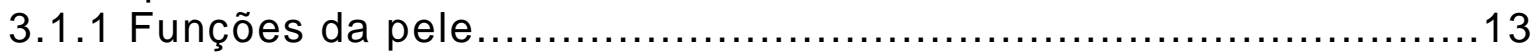

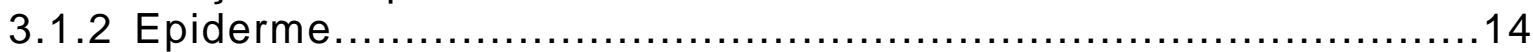

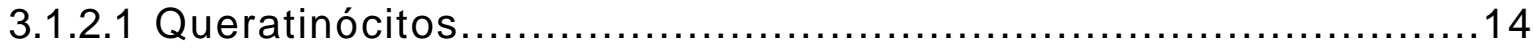

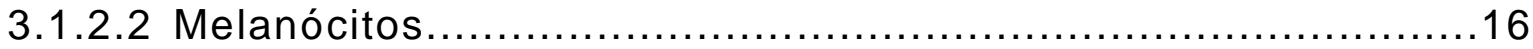

3.1.2.3 Células de Langerhans................................................. 17

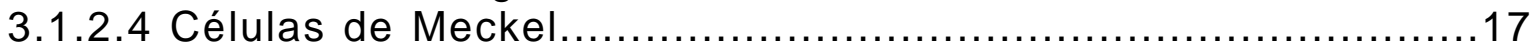

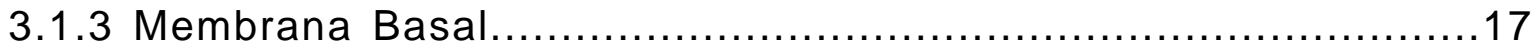

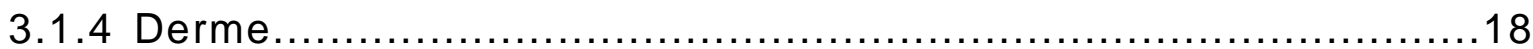

3.1.4.1 Componentes Celulares........................................... 19

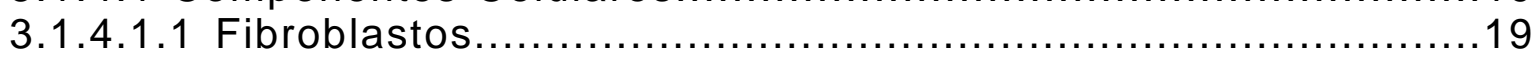

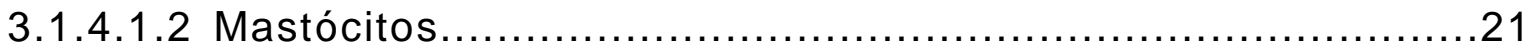

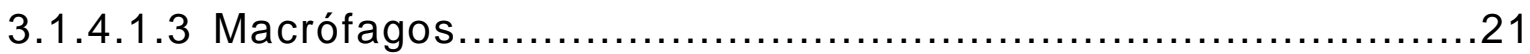

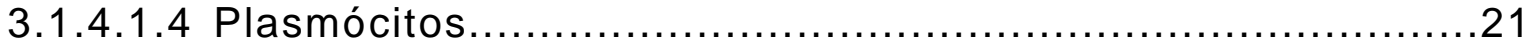

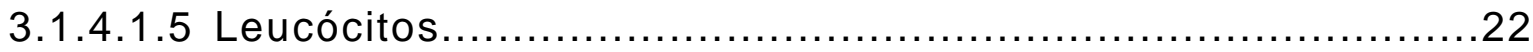

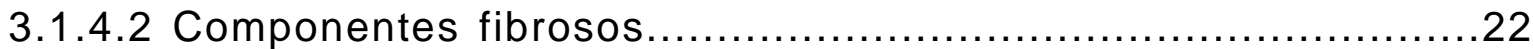

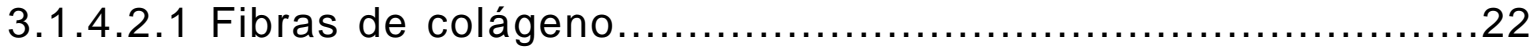

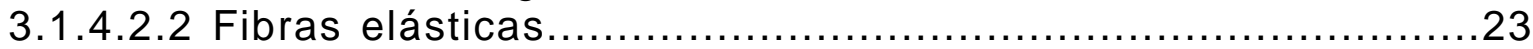

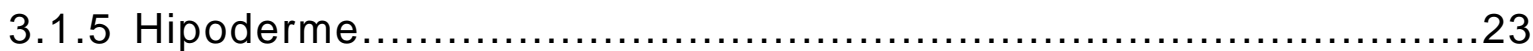

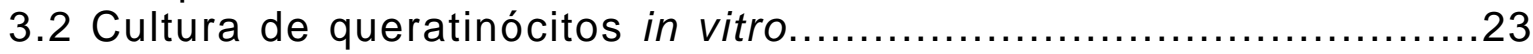

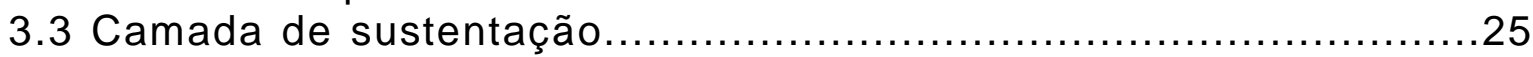

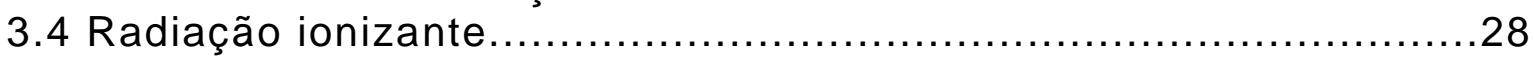

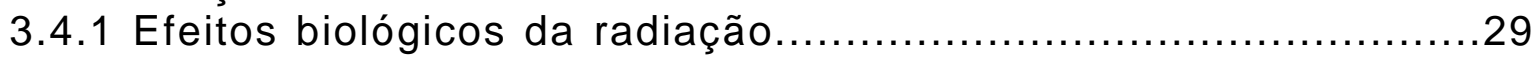

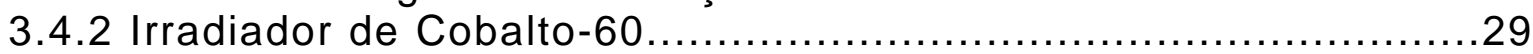

3.5 Substitutos ao Soro Fetal Bovino no meio de cultura....................30

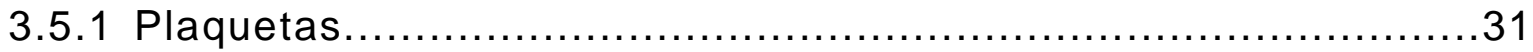

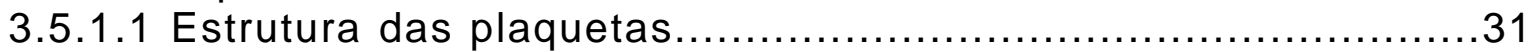

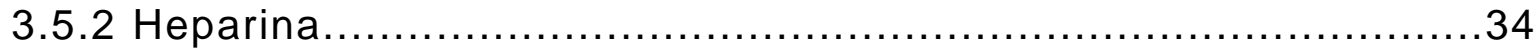

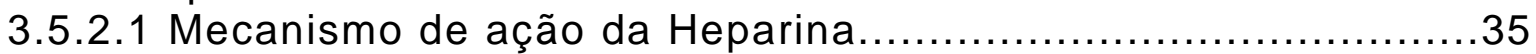

3.5.3 Lisados de Plaquetas...................................................38

3.5.3.1 Fatores de Crescimento contidos no lisado de plaquetas.........39

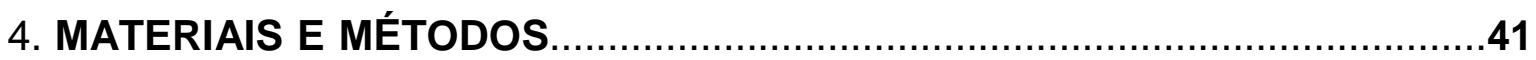

4.1 Obtenção dos materiais biológicos.........................................41

4.2 Descarte de material biológico.......................................... 41

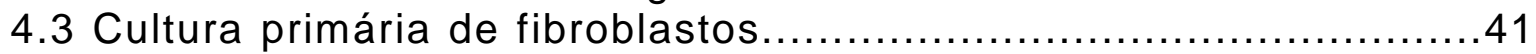

4.3.1 Amplificação dos fibroblastos.......................................42

4.4 Preparo do lisado de plaquetas (LP) para o teste de heparina.......43

4.4.1 Preparo dos meios de cultura contendo lisados de plaquetas.....44

4.4.2 Ensaio de proliferação dos fibroblastos humanos

em meio de cultura suplementado com lisado de plaquetas................44

4.4.3 Ensaio de adesão celular................................................44 
4.4.4 Ensaio de comparação da viabilidade celular......................45

4.5 Preparo do lisado de plaquetas para o teste do tipo sanguíneo....45

4.5.1 Ensaio de adesão celular.............................................46

4.5.2 Ensaio de comparação de viabilidade celular......................46

4.6 Padronização da dose de irradiação.................................47

4.7 Avaliação da influência do tipo da camada de sustentação e da suplementação no meio na cultura no cultivo de queratinócitos..........47

4.7.1 Preparo do lisado de plaqueta do tipo sanguíneo O (PLO)........47

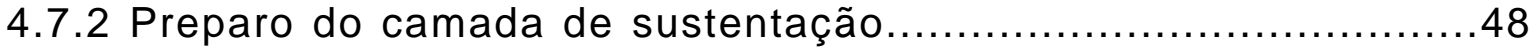

4.7.3 Cultura dos Queratinócitos .........................................48

4.7.4 Teste de eficiência de formação de colônias........................49

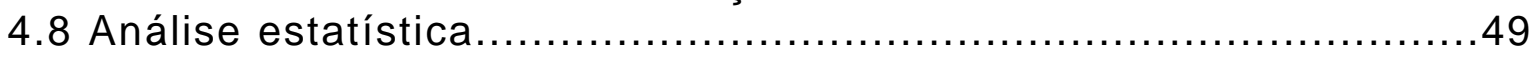

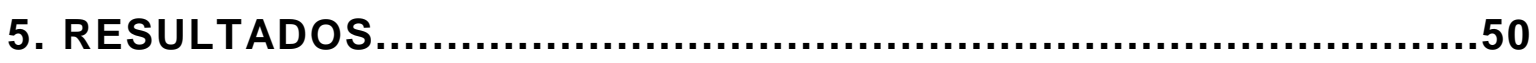

5.1 Teste de adição de heparina nos concentrados de plaquetas.......50

5.1.1 Proliferação dos fibroblastos com soro fetal bovino

versus lisados de plaquetas .............................................. 50

5.1 .2 Avaliação da adesão celular........................................ 52

5.1.3 Comparação da viabilidade celular dos fibroblastos

humanos nos diferentes meios em relação ao meio com SFB...........54

5.2 Avaliação do efeito dos tipos sanguíneos das origens das plaquetas

lisadas......................................................................... 59

5.2.1 Avaliação da Adesão Celular.......................................59

5.2.2 Comparação da viabilidade celular dos fibroblastos humanos

nos diferentes meios em relação ao meio com SFB.....................60

5.3 Determinação da dose de irradiação necessária para

inativação da proliferação dos fibroblastos humanos...................64

5.4 Avaliação dos efeitos dos tipos de camadas de sustentação,densidade e suplementação do meio de cultura no cultivo

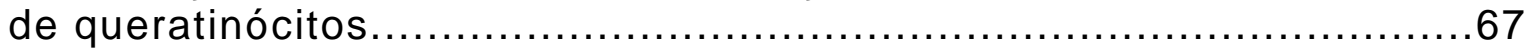

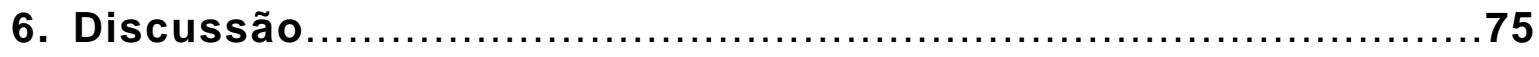

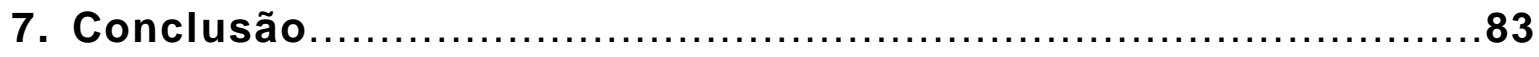

APÊNDICE A Preparo das EFC nas diferentes condições............84

ANEXO A - Aprovação do Comitê de Ética em Pesquisa (COEP)...................85

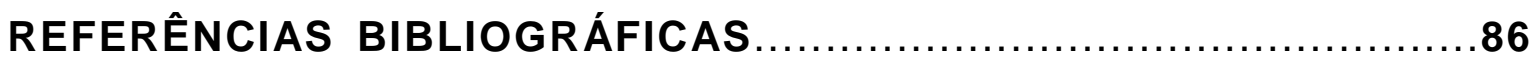




\section{INTRODUÇÃO}

A pele constitui a primeira barreira protetora contra as agressões do meio ambiente, não permitindo a entrada de substâncias estranhas no organismo e ao mesmo tempo evitando a perda de água, colaborando na termorregulação e sediando a formação de vitamina $D$ (Junqueira \& Carneiro, 2004).

A pele é composta, essencialmente, de duas camadas de tecido: camada superior, denominada epiderme e camada profunda, a derme. Abaixo e em continuidade com a pele encontra-se a hipoderme, que the serve de união com os órgãos subjacentes (Junqueira \& Carneiro, 2004; Gartner \& Hiatt, 2007).

A epiderme é a camada mais externa e compacta. Não possui sistema de irrigação sanguínea direta, sendo nutrida pela permeação dos nutrientes oriundos da derme, por capilaridade. Os principais componentes da epiderme são os queratinócitos, células especializadas que, além de produzir queratina, sofrem processo de estratificação e descamação (Peyrefitte et al., 1998; Harris, 2009).

A derme é composta por tecidos conectivos fibrosos de elastina e colágeno. Nela estão presentes vasos sanguíneos e linfáticos, além de numerosas terminações nervosas. Uma das suas principais funções é de servir como tecido de sustentação para a epiderme. Na derme são encontrados os fibroblastos e as células do sistema imunológico. Sendo que os fibroblastos são responsáveis pela síntese das diferentes macromoléculas que compõe a matriz extracelular, e possui uma intensa atividade durante o processo de cicatrização (Peyrefitte et al., 1998).

A hipoderme é constituída de um tecido gorduroso denominado tecido adiposo, ricamente servido por nervos e vasos sanguíneos. O tecido adiposo está envolvido na regulação de temperatura, proteção contra ações mecânicas, suporte e depósito nutricional (Peyrefitte et al., 1998; Harris, 2009).

$\mathrm{Na}$ interrupção da continuidade da pele, como é o caso de pessoas que sofreram queimaduras graves, abrem-se vias para infecções e septicemia (Herson, 1999). Com a preocupação de evitar estas infecções, condutas terapêuticas foram desenvolvidas com o objetivo de recuperar essa pele, sendo que uma das alternativas foi o cultivo de queratinócitos.

Em 1975, Rheinwald e Green publicaram um método de cultivo de queratinócitos, onde utilizaram fibroblastos murinos irradiados para formar uma 
camada de sustentação (feeder layer). Esta camada tornou possível o cultivo desses queratinócitos por período de tempo superior ao obtido na cultura destas células em monocamada (Rheinwald \& Green, 1975).

Para a obtenção dos fibroblastos como camada de sustentação, Rheinwald e Green, utilizaram uma linhagem celular de fibroblastos murinos $(\mathrm{NIH}-$ 3T3) modificada Todaro e Green (1963), denominada 3T3-J2, servindo, desse modo, como suporte na cultura de queratinócitos (Rheinwald, 1989).

A irradiação dos fibroblastos murinos foi necessária para controlar seu crescimento e este não se apor ao crescimento das células de interesse a serem cultivadas. A dose de 60 Grays (Gy) foi preconizada por Rheinwald e Green como suficiente para inibir a duplicação dos fibroblastos (Rheinwald \& Green, 1975).

Com a formação da camada de sustentação, constituída pelos fibroblastos murinos irradiados, foi possível o desenvolvimento dos queratinócitos em colônias e a propagação das células em culturas posteriores tornando possível a confecção de epitélios transplantáveis (Andreassi, 1992; De Luca \& Cancedda, 1992; Mathor, 1994; Herson, 1999).

Além de constituírem a camada de sustentação, os fibroblastos irradiados produzem fatores de crescimento, os quais contribuem para o aperfeiçoamento da cultura dos queratinócitos. Quando a relação entre camada de sustentação e queratinócitos é otimizada, estes últimos podem crescer e se diferenciar de maneira controlada, sendo possível a replicação destas células em cultura subseqüente (De Luca \& Cancedda, 1992).

A partir da metodologia proposta por Rheinwald e Green, diversas aplicações clínicas se tornaram possíveis, incluindo: o tratamento de grandes queimados (De Luca \& Cancedda, 1992, Herson, 1999, Atiyeh \& Costagliola, 2007), úlceras crônicas (De Luca et al.,1992), nevus gigante congênito (De Luca \& Cancedda, 1992, Inoue et al., 2006), epidermólise bolhosa juncional (De Luca \& Cancedda, 1992), reparos cirúrgicos e terapia gênica (De Luca \& Cancedda, 1992; Inoue et al., 2006 ).

Por mais de 30 anos, a utilização do meio de cultura, enriquecido com soro bovino, e dos fibroblastos murinos, com a taxa de proliferação controlada por irradiação e ou por ação de drogas anti-cancerígenas, vem desempenhando com sucesso o seu papel de auxiliar no desenvolvimento dos queratinócitos em cultura. Porém, quando o objetivo final da cultura de queratinócitos é o de servir 
como enxerto para pacientes que tiveram danos causados à pele por diversas razões, o uso de qualquer componente de origem animal empregado na "confecção" do enxerto não é desejável, pois existe uma preocupação crescente acerca da possibilidade de transmissão de várias doenças causadas por prions e viroses animais, por exemplo, Encefalopatia Espongiforme Bovina (EEB) (Bullock et al., 2006).

Tais preocupações, impulsionaram diversos pesquisadores a buscar alternativas aos componentes de origem animal empregados nesses métodos, focando suas atenções principalmente sobre o Soro Fetal Bovino, por ser este uma fonte de nutrientes, presente no meio de cultura de vários tipos celulares (Aldén et al., 2007).

Atualmente, lisado de plaquetas humanas tem sido testado como potente substituto para o soro fetal bovino em diversas culturas primarias de células humanas (Blande et al., 2009). Isto porque as plaquetas carregam dentro de si, grânulos a que contêm diversos fatores de crescimento envolvidos na reparação tissular (Mirabet et al., 2008).

O outro componente xenobiótico importante é a camada de sustentação constituída linhagem de fibroblastos murinos. Algumas linhagens celulares foram testadas para formação dessa camada de sustentação, mas de todas as células utilizadas, apenas os fibroblastos murinos de linhagem 3T3-J2 e os fibroblastos provenientes de derme humana obtiveram resultados mais eficientes. Sendo que, os estudos foram desenvolvidos alterando somente a camada de sustentação por fibroblastos humanos, obtendo-se um desenvolvimento mais lento dos queratinócitos (Rheinwald \& Green, 1975; Green et al., 1977).

Estes estudos continuam em evolução, na busca de alternativas eficazes à utilização de elementos xenobióticos nas culturas de células humanas para fins clínicos, sendo este o objetivo de nosso trabalho. 


\section{OBJETIVO}

Cultivar fibroblastos humanos em meio enriquecido com lisado de plaquetas e determinar a dose de irradiação dessas células, para obtenção da camada de sustentação na cultura de células da epiderme.

\subsection{Objetivo específico}

- Padronizar a técnica de lise das plaquetas e preparo do meio de cultura;

- Verificar o efeito da substituição de soro fetal bovino por lisado de plaquetas na proliferação, adesão e viabilidade dos fibroblastos humanos;

- Avaliar a influência dos lisados de plaquetas provenientes de diferentes tipos sanguíneos;

- Padronizar a dose de irradiação suficiente para inibir a duplicação dos fibroblastos humanos;

- Comparar o desenvolvimento das culturas de queratinócitos em camada de sustentação constituída de fibroblastos humanos em relação aos murinos. 


\section{REVISÃO DA LITERATURA}

\subsection{A pele}

A pele é um manto de revestimento do corpo, indispensável à vida e que isola os componentes internos do organismo do ambiente externo (Sampaio \& Rivitti, 2007). É o maior órgão do corpo humano, apresentando uma área que varia de $0,2 \mathrm{~m}^{2}$ (no nascimento) a 1,8-2,5 $\mathrm{m}^{2}$ em um ser humano adulto e uma espessura que pode variar de 1,5 a $4 \mathrm{~mm}$ (Harris, 2009).

A pele é composta por duas camadas: uma externa, a epiderme, e uma camada mais profunda de tecido conjuntivo, a derme. A epiderme é composta por um epitélio estratificado pavimentoso queratinizado, de origem ectodérmica. Localizada a abaixo e interligando-se com a epiderme está a derme, de origem mesodérmica e constituída por um tecido conjuntivo denso não modelado. Abaixo e em continuidade com a derme encontra-se a hipoderme, que não faz parte da pele, apenas the serve de união com os órgãos subjacentes. A interface entre a epiderme e a derme é formada por projeções do tecido conjuntivo da derme, as papilas dérmicas, que se encaixam em reentrâncias da epiderme, aumentando a coesão entre essas duas camadas (Junqueira \& Carneiro, 2004; Gartner \& Hiatt, 2007).

\subsubsection{Funções da pele}

Graças às propriedades físicas, químicas e biológicas de suas estruturas, a pele pode exercer múltiplas funções, tais como: proteção física, proteção imunológica, termorregulação, percepção e funções metabólicas (Junqueira \& Carneiro, 2004; Sampaio \& Rivitti, 2007; Young et al., 2007):

- Proteção física: a camada córnea da epiderme constitui uma barreira de proteção para as estruturas internas do organismo à penetração de agentes externos e, ao mesmo tempo, impede perdas de água, eletrólitos e outras substâncias do meio interno;

- Proteção imunológica: graças às células imunológicamente ativas, presentes na derme, a pele é um órgão de grande atividade imunológica, onde atuam os componentes da imunidade humoral e celular; 
- Termorregulação: é exercida pelos sistemas sudoríparo e vascular da pele. As glândulas sudoríparas secretam o suor que ao se evaporar, esfria a superfície corpórea, e, os vasos sanguíneos, que através da dilatação ou constrição, ampliam ou diminuem o fluxo sanguíneo periférico, permitindo maior ou menor dissipação de calor;

- Percepção: através da complexa e especializada rede nervosa cutânea, a pele é o órgão receptor sensitivo do calor, frio, dor e tato;

- Funções metabólicas: a mais importante função metabólica da pele é a síntese de vitamina D3 pela ação da luz ultravioleta do sol sobre o precursor 7-deidrocolesterol. A vitamina D3 formada é em seguida processada no fígado e no rim para produzir um agente ativo, que é importante no metabolismo do cálcio e na formação de tecido ósseo.

\subsubsection{Epiderme}

A epiderme é a camada mais externa, compacta e impermeável da pele. Apresenta uma espessura variável entre $0,06 \mathrm{~mm}$ (face) até 1,3 $\mathrm{mm}$ (palma da mão). Não possui sistema de irrigação sanguínea direta, sendo nutrida pela permeação dos nutrientes procedentes da derme por capilaridade (Peyrefitte et al., 1998; Harris, 2009).

Constituída por epitélio estratificado pavimentoso queratinizado, a epiderme é formada por quatro tipos celulares: os queratinócitos, que representam $80 \%$ do conjunto das células epidérmica; os melanócitos, que constituem 13\%; as células de Langehans, que correspondem em torno de $4 \%$ e por fim as células de Merkel (aproximadamente 3\%) (Peyrefitte et al., 1998).

\subsubsection{Queratinócitos}

Os queratinócitos são os principais componentes da epiderme, sendo células especializadas na fabricação de uma substância muito resistente, a queratina, que preenche as células mais superficiais da epiderme para formar a camada córnea (Peyrefitte et al., 1998; Harris, 2009).

Os queratinócitos estão continuamente sendo descamados da superfície da epiderme, e esta população de células é constantemente renovada, por meio da atividade mitótica dos queratinócitos nas camadas basais 
da epiderme. À medida que as novas células vão sendo formadas, as células da camada situada na região superior vão sendo deslocadas em direção à superfície. Ao longo do seu percurso à superfície, os queratinócitos se diferenciam e começam a acumular no seu citoplasma filamentos de queratina. Finalmente, ao se aproximar da superfície, as células morrem e são descamadas (Gartner \& Hiatt, 2007).

Devido às importantes modificações morfofuncionais dos queratinócitos durante a sua migração desde a camada basal da epiderme até a sua superfície, a epiderme se divide em cinco camadas distintas (FIG. 1):

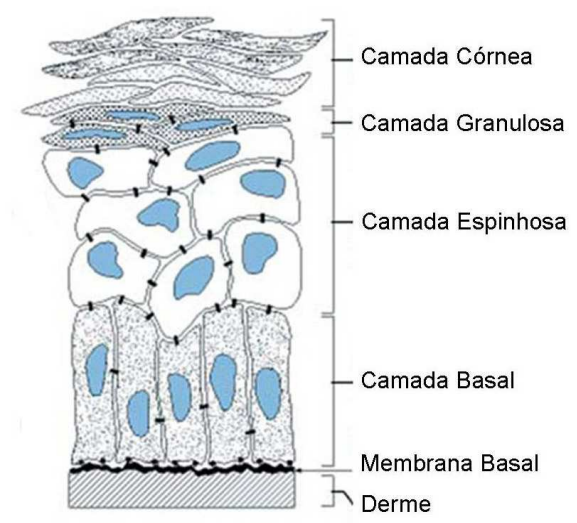

Figura 1- Esquema representativo das camadas da epiderme (modificada de Presland \& Jurevic, 2002).

- Camada basal: constituída por uma única camada de células cubóides, basófilas, que repousam sobre a membrana basal que separa a epiderme da derme. A camada basal, rica em células-tronco da epiderme, apresenta intensa atividade mitótica, sendo responsável pela constante renovação da epiderme, que ocorre a cada 15 a 30 dias.

- Camada espinhosa: é a camada mais espessa da epiderme, é constituída por células poliédricas achatadas, de núcleo central, citoplasma com curtas expansões que contêm feixes de filamentos de queratina (tonofilamentos). Essas expansões citoplasmáticas se aproximam e se mantêm unidas com as células vizinhas através de desmossomos, conferindo o aspecto espinhoso desse estrato. À medida que os queratinócitos se deslocam em direção a superfície através do estrato espinhoso, eles continuam a sintetizar tonofilamentos, os quais se agrupam formando feixes, denominados 
tonofibrilas. Estas são importantes para a manutenção da coesão intercelular e na resistência ao atrito.

- Camada granulosa: constituída por três a cinco camadas de queratinócitos achatados, de núcleo central e citoplasma carregado de grânulos de queratohialina. Estes grânulos contêm proteínas ricas em histidina fosforilada e cistina, que estão associadas ao processo de queratinização das células. As células da camada granulosa também contêm grânulos lamelares, que por exocitose, liberam o seu conteúdo lipídico no espaço extracelular, formando uma barreira impermeável.

- Camada lúcida: presente apenas na epiderme de pele espessa, sendo constituída por uma delgada camada de células achatadas, cujos núcleos e organelas foram digeridos por enzimas dos lisossomos. O citoplasma apresenta numerosos filamentos de queratina densamente compactados, dispostos paralelamente á superfície da pele.

- Camada córnea: camada mais superficial da pele, formada por várias camadas de células achatadas e intensamente queratinizadas. Estas células não apresentam núcleo e organelas, mas o citoplasma apresenta-se repleto com filamentos de queratina transformando estas células em placas sem vida que descamam continuamente (Junqueira \& Carneiro, 2004; Gartner \& Hiatt, 2007; Young et al., 2007; Harris, 2009).

\subsubsection{Melanócitos}

Os melanócitos são células dendríticas, que se originam da crista neural, localizam-se na junção da derme com a epiderme ou entre os queratinócitos da camada basal da epiderme (Junqueira \& Carneiro, 2004; Harris, 2009).

Os melanócitos produzem pigmentos de melanina, os quais são responsáveis pela coloração da pele e dos cabelos. Este pigmento pode variar sua coloração desde marrom-amarelo até preto, e tem função protetora contra danos causados pela luz ultravioleta em excesso (Young et al., 2007).

A melanina é sintetizada pelos melanócitos a partir da tirosina, no interior de organelas citoplasmáticas especificas, denominadas melanossomas, as quais são transferidas para os queratinócitos através dos prolongamentos 
citoplasmáticos dos melanócitos. Nos queratinócitos, os melanossomas situam-se na região supranuclear, proporcionando assim proteção ao DNA contra os efeitos prejudiciais da radiação solar (Junqueira \& Carneiro, 2004; Young et al., 2007).

\subsubsection{Células de Langerhans}

As células de Langerhans são as células para reconhecimento e processamento de antígenos da pele, e expressam marcadores de superfície semelhantes aos linfócitos e macrófagos. Elas monitoram constantemente a camada epidérmica com seus prolongamentos citoplasmáticos dendríticos e são potentes estimuladores da resposta imunológica na apresentação de antígeno às células T. (Young et al., 2007).

\subsubsection{Células de Meckel}

As células de Meckel são receptores para o tato, localizam-se na parte mais profunda da epiderme, apoiadas a membrana basal e presas aos queratinócitos pelo desmossomos. Em contato com as células de Meckel existe uma estrutura em forma de disco, onde se inserem fibras nervosas responsáveis pela condução de impulsos para o sistema nervoso central (Junqueira \& Carneiro, 2004).

\subsubsection{Membrana Basal}

Na superfície de contato entre o tecido epitelial e o tecido conjuntivo, há uma fina camada acelular chamada membrana basal, que ao ser observada ao microscópio eletrônico, mostra-se constituída por uma lâmina basal e uma lâmina reticular (Gartner \& Hiatt, 2007).

Lâmina basal é a porção superficial da membrana da basal, formada principalmente por fina trama de colágeno tipo IV e glicoproteínas estruturais, fribronectina, laminina e entactina (Gartner \& Hiatt, 2007; Young et al., 2007).

A lâmina basal tem diversas atividades, além das funções estruturais e filtrantes de moléculas, a lâmina basal também pode: influenciar a polaridade celular; promover a sobrevivência, proliferação e diferenciação das células, ligando-se com fatores de crescimento; modular o metabolismo das células; organizar as proteínas na membrana plasmática das células adjacentes (Junqueira \& Carneiro, 2004; Alberts et al., 2008). 
A lâmina reticular é a interface entre a lâmina basal e o tecido conjuntivo subjacente. É produzida por fibroblastos e constituída por colágenos dos tipos I e III (Gartner \& Hiatt, 2007).

\subsubsection{Derme}

A derme é o tecido conjuntivo no qual se apóia a epiderme e une a pele à hipoderme subjacente (Junqueira \& Carneiro, 2004). Apresenta espessura variável ao longo do organismo, desde $0,6 \mathrm{~mm}$, nas pálpebras até $3 \mathrm{~mm}$ na palma da mão e na planta do pé (Gartner \& Hiatt, 2007).

A derme é constituída por fibras de colágeno e elastina dispersas em uma substância fundamental amorfa, juntamente com os fibroblastos que sintetizam o colágeno, as fibras de elastina e os demais componentes da matriz extracelular. Outras estruturas presentes são os vasos sangüíneos, os anexos cutâneos e as terminações nervosas sensitivas (Young et al., 2007).

A arquitetura de derme é formada por duas camadas: uma derme papilar superficial localizada abaixo da epiderme e uma derme reticular, mais profunda que se limita com a hipoderme (FIG. 2):

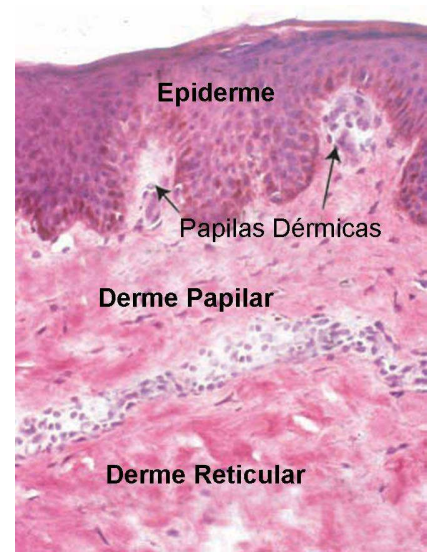

FIGURA 2- Corte histológico da pele, onde podem ser observadas as duas camadas da derme com as papilas dérmicas penetrando na epiderme (modificada de Sorrel \& Caplan, 2004).

- Derme papilar: constituída por um tecido conjuntivo frouxo que forma as papilas dérmicas. Esta camada apresenta delgadas fibras de colágeno do tipo I e III entrelaçadas com fibras do sistema elástico formando uma rede frouxa. Na papila dérmica também são encontradas fibrilas especiais de 
colágeno, que se estendem da membrana basal para dentro da derme, fixando a derme à epiderme;

- Derme reticular: constituída por tecido conjuntivo denso não modelado, possui espessas fibras de colágeno tipo I e fibras elásticas dispostas paralelamente à superfície. Nesta camada são encontrados os vasos sangüíneos e linfáticos, nervos e anexos cutâneos (Junqueira \& Carneiro, 2004; Gartner \& Hiatt, 2007; Harris, 2009).

\subsubsection{Componentes Celulares}

\subsection{Fibroblastos}

Os fibroblastos originam-se de células mesenquimais indiferenciadas e tem como principal função a manutenção da integridade do tecido conjuntivo, pela síntese dos componentes da matriz extracelular (Gartner \& Hiatt, 2007; Masseno et al., 2010). Além dessa função, os fibroblastos estão também envolvidos na secreção de fatores de crescimentos e citocinas que controlam a proliferação e diferenciação das células da epiderme (Junqueira \& Carneiro, 2004, Wong et al., 2007).

Como maior componente celular do tecido conjuntivo, os fibroblastos são células capazes de modular a sua capacidade metabólica, sendo que as células com intensa atividade de síntese são denominadas fibroblastos ativos, enquanto as células quiescentes são chamadas de fibrócitos (Junqueira \& Carneiro, 2004, Gartner \& Hiatt, 2007).

Os fibroblastos ativos são células alongadas e fusiformes, que apresentam um citoplasma rico em retículo endoplasmático rugoso e aparelho de Golgi bem desenvolvido (Junqueira \& Carneiro, 2004, Gartner \& Hiatt, 2007).

Os fibrócitos são células menores do que os fibroblastos e possuem um citoplasma acidófilo com pouca quantidade de retículo rugoso (Gartner \& Hiatt, 2007). Durante a cicatrização, os fibrócitos podem ser recrutados do tecido adjacente não lesado, se revertendo para o estado de fibroblasto e reativando sua capacidade de síntese (Junqueira \& Carneiro, 2004; Masseno et al., 2010).

De acordo com Sorrel e Caplan, os fibroblastos dermais são constituídos de duas subpopulações de fibroblastos que residem em camadas distintas da derme, definidas por derme papilar e reticular. Estas células quando 
cultivadas in vitro apresentam diferentes características, quanto a sua capacidade de crescimento, proliferação e produção de moléculas da matriz extracelular (Sorrel \& Caplan, 2004; Nolte et al., 2008).

Bayreuther e col. (1988), em seus estudos, também verificaram a existência de subpopulações diferenciadas de fibroblastos originados do mesmo tecido. Duas grandes populações de fibroblastos foram detectadas, uma denominada de fibroblastos progenitores replicativos (MF) e uma outra chamada de fibrócitos pós-mitóticos irreversíveis (PMF). De acordo com análises morfológicas e bioquímicas, observou-se que os fibroblastos humanos, tanto in vitro quanto in vivo, diferenciam-se ao longo da sua vida util em células mitoticamente ativas MF I, MF II, MF III, antes de diferenciar irrevesivelmente em PMF IV, PMF V e PMF VI (FIG. 3) (Bayreuther et al., 1988; Rodemann et al., 1989; Nolte et al., 2008).

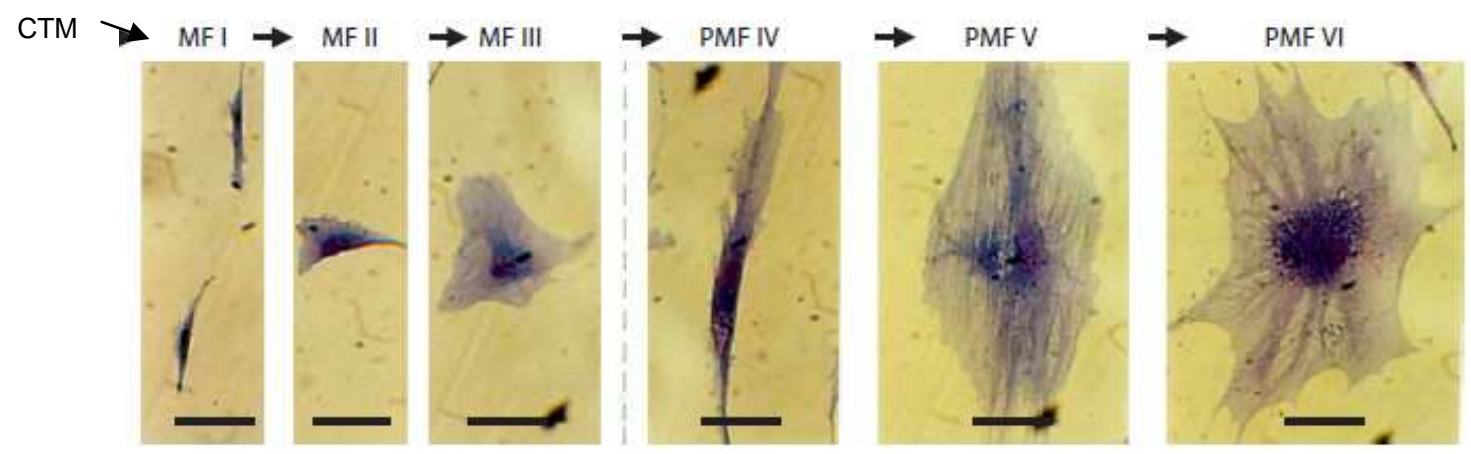

FIGURA 3: Representação da diferenciação das células tronco mesenquimais (CTM) em células mitoticamente ativas, MF I, MF II, MF III. As células MF III, o último tipo de MF mitoticamente ativa, se diferencia ao tipo celular PMF IV e PMF V, seguida de diferenciação na célula terminal do tipo PMF VI (modificada de Nolte et al, 2008). Escala da barra $=50 \mu \mathrm{m}$.

As células MF I têm a maior capacidade de replicação, podendo se dividir por 25-30 vezes, antes de diferenciar-se espontaneamente em células MF II. Estas podem se dividir cerda de 15-20 vezes antes de se diferenciar em células MF III, que tem o potencial de dividirem-se por apenas 5-8 vezes antes de diferenciar-se irreversivelmente em PMF IV. Dentro de 2-3 semanas, este tipos de células se diferenciam em PMF V e posteriormente em PMF VI (Lara et al., 1996; Nolte et al., 2008).

No organismo, deve ser mantida uma relação constante entre MF e PMF na proporção de 2:1, pois este último produz cerca de 5-8 vezes mais 
colágeno do que MF e fornece a proporção correta de colágenos tipos I, II e V, necessários para a homeostase e manutenção do tecido conjuntivo. Distúrbios decorrentes de fatores endógenos ou exógenos, que podem levar a uma alteração nesta proporção celular, podem resultar em uma patologia (Nolte et al., 2008).

\subsection{Mastócitos}

Os mastócitos são células globulosas e com citoplasma repleto de grânulos contendo histamina e heparina. O seu núcleo é central e de difícil observação.

O mastócitos origina-se de células-tronco da medula óssea e circulam no sangue, cruzando a parede de vênulas e capilares e ao penetrar nos tecidos, começam a proliferar e diferenciar. Os mastócitos atuam nas reações imunes e medeiam os processos inflamatórios e as reações de hipersensibilidade imediata (Junqueira \& Carneiro, 2004; Gartner \& Hiatt, 2007).

\subsection{Macrófagos}

Os macrófagos são células que medem entre 10 a $30 \mu \mathrm{m}$ de diâmetro, e possuem características morfológicas muito variáveis dependem do seu estado de atividade funcional e tecido que habitam.

São originados de células precursoras da medula óssea que se dividem produzindo os monócitos. Estes passam para o sangue e atravessando a parede de vênulas e capilares penetram no tecido conjuntivo, onde amadurecem e adquirem a morfologia de macrófagos.

Os macrófagos participam no mecanismo de defesa, fagocitando e destruindo restos celulares, microrganismos e elementos inertes que penetrem no organismo. Os macrófagos também desempenham um papel fundamental na apresentação de antígenos para os linfócitos (Junqueira \& Carneiro, 2004; Gartner \& Hiatt, 2007).

\subsection{Plasmócitos}

Os plasmócitos são células grandes e ovóides, com $20 \mu \mathrm{m}$ de diâmetro, com núcleo excêntrico e um tempo de vida curto de 2 a 3 semanas. Localizam-se dispersos por todo tecido conjuntivo, porém estão presentes em 
maior número em áreas sujeitas a entrada de microrganismos e proteínas estranhas e nas inflamações crônicas. Os plasmócitos são células originárias dos linfócitos B e são responsáveis pela imunidade humoral (Gartner \& Hiatt, 2007).

\subsection{Leucócitos}

Os leucócitos são glóbulos brancos que circulam na corrente sangüínea, e participam das defesas celulares e imunocelulares do organismo. São divididos em dois grupos: granulócitos e agranulócitos (Junqueira \& Carneiro, 2004; Gartner \& Hiatt, 2007).

Os gránulócitos têm núcleo de forma irregular e apresentam no citoplasma grânulos específicos. Os três tipos de granulócitos são: neutrófilos, eosinófilos e basófilos.

Os agranulócitos têm o núcleo mais regular e o citoplasma não possui granulações específicas. Existem dois tipos de agranulócitos: os linfócitos e os monócitos.

Quando os tecidos são invadidos por microrganismos, substâncias quimiotaxias provocam a migração dos leucócitos ao local da invasão, logo estas células atravessam as paredes dos vasos sangüíneos e entram no tecido participando do processo inflamatório (Junqueira \& Carneiro, 2004).

\subsubsection{Componentes fibrosos}

\subsection{Fibras de colágeno}

São fibras sintetizadas por fibroblastos e miofibroblastos, células musculares e várias células epiteliais (Harris, 2009). Como principal componente da pele, cartilagem e do osso, os colágenos são as proteínas mais abundantes do organismo, representando $25 \%$ da massa protéica (Alberts et al., 2008).

O colágeno é uma estrutura longa rígida formada por três cadeias polipeptídica (cadeias $\alpha$ ), enroladas umas às outras formando uma fita tripla helicoidal. Auxiliando a formação desta fita helicoidal, encontram-se os aminoácidos prolina e glicina. O primeiro estabiliza a conformação da hélice em cada cadeia $\alpha$ e o segundo permite que as três cadeias $\alpha$ se agrupem firmemente formando assim a super-hélice final (Young et al., 2007; Alberts et al., 2008). 
Até o momento foram descritos mais de 12 tipos diferentes de colágenos, entretanto, os participantes da pele são os tipos: I, III, IV, V, VI e VII (Harris, 2009).

\subsection{Fibras elásticas}

Responsáveis por fornecer propriedades elásticas à pele, as fibra elásticas são sintetizadas pelos fibroblastos na forma de fibras delgadas, longas que se ramificam pelo tecido conjuntivo (Gartner \& Hiatt, 2007; Harris, 2009).

As fibras elásticas são constituídas por um núcleo central amorfo de elastina, circundada por uma camada de microfibrilas tubulares de $10 \mathrm{~nm}$ de diâmetro (Sampaio \& Rivitti, 2007; Harris, 2009).

A elastina é a uma importante proteína constituinte do chamado sistema elástico da matriz celular. Ela contém os aminoácidos desmosina e isodesmosina, que conferem as propriedades de distensão e recolhimento elástico das fibras de elastina (Junqueira \& Carneiro, 2004, Young et al., 2007).

\subsubsection{Hipoderme}

A hipordeme é a camada mais profunda e subjacente a pele, de espessura variável, formada principalmente por tecido adiposo, que é ricamente servido de vasos sangüíneos e nervos. Funcionalmente, a hipoderme está envolvida na regulação de temperatura, isolamento térmico, depósito nutricional, proteção mecânica do organismo às pressões e traumatismo externo e na motilidade da pele sobre as estruturas subjacentes (Sampaio \& Rivitti, 2007, Young et al., 2007).

\subsection{Cultura de queratinócitos in vitro}

A possibilidade de obtenção de epitélios transplantáveis a partir do cultivo de células in vitro, especificamente os queratinócitos, impulsionou a pesquisa e o desenvolvimento de novos tratamentos de lesões cutâneas ao ser utilizado como substituto cutâneo, assim diversas aplicações clínicas tornaram-se possíveis, como o tratamento de grandes queimados (De Luca \& Cancedda, 1992, Herson, 1999, Atiyeh \& Costagliola, 2007), úlceras crônicas (De Luca et al.,1992) nevus gigante congênito (De Luca \& Cancedda, 1992, Inoue et al., 
2006), epidermólise bulhosa juncional (De Luca \& Cancedda, 1992), tatuagens (Inoue et al., 2006) e reparos cirúrgicos (De Luca \& Cancedda, 1992; Inoue et al., 2006 ).

As primeiras tentativas de cultivo dos queratinócitos in vitro foram pela técnica de explante, método que promovia a liberação e a migração dos queratinócitos na direção centrífuga, a partir dos fragmentos de pele posicionados na superfície de cultivo. No entanto, esse tipo de cultura se mostrou ineficaz, uma vez que os queratinócitos eram contaminados pelo crescimento dos fibroblastos, tornando-se impossível o desenvolvimento da mesma. Posteriormente, houve várias tentativas de cultivo, como a utilização da enzima tripsina que promovia a dissociação dos queratinócitos, possibilitando cultivo destas células epidérmicas em monocamadas. Por meio destes estudos, pode-se observar que os queratinócitos se duplicavam em uma extensão limitada e ficavam sujeitos a um processo de diferenciação terminal que comprometia a capacidade de propagação dessas células em culturas subseqüentes (Andreassi, 1992; Herson, 1999; Parkison \& Yeudall, 2002).

As limitações dessas técnicas foram superadas por Rheinwald e Green em 1975. Estes autores publicaram metodologia padronizada, eficaz para obtenção e cultivo de células da epiderme, priorizando a proliferação dos queratinócitos e melanócitos em detrimento aos fibroblastos. Esta metodologia consistia em semear queratinócitos dissociados do tecido sobre uma camada de sustentação (feeder-layer) composta por fibroblastos murinos de linhagem 3T3, após estes terem a taxa de proliferação controlada pela ação de radiação ionizante ou de drogas anti-cancerígenas como a Mitomicina C (Green et al., 1979; Rheinwald, 1989; Tenchini et al., 1992; Freshney, 2002).

Uma característica importante na cultura de queratinócitos é a capacidade destes formarem colônias a partir de uma única célula semeada (Rheinwald \& Green, 1975; Green et al., 1979, Tenchini et al., 1992). Essa habilidade se deve as células clonogênicas, classificadas em holoclones, meroclones e paraclones, segundo seu estágio de diferenciação. (Barrandon \& Green, 1987, Barrandon, 1993).

A utilização dos fibroblastos irradiados como camada se sustentação permitiu um eficiente crescimento da cultura de queratinócitos, uma vez que fisiologicamente os queratinócitos dependem, para sua manutenção e 
crescimento, da presença dos fibroblastos e os produtos sintetizados por eles. Quando esta relação entre camada de sustentação e queratinócitos é otimizada, estes podem crescer e se diferenciar de uma maneira mais controlada (Rheinwald \& Green,1975; Maas-Szabowski et al, 2002).

As colônias de queratinócitos, que se originaram em cultura, crescem gradualmente, assim removendo a camada de sustentação da superfície da placa, até os fibroblastos estarem virtualmente ausentes. Esta eliminação dos fibroblastos ocorre quando essa cultura atinge um estágio denominado de confluência, ou seja quando a placa ou a garrafa de cultura se torna totalmente preenchida com os queratinócitos (Barreca et al.,1992).

O crescimento da colônia se dá, quando as células basais, encontradas na periferia da colônia, se duplicam e crescem aumentando radialmente o tamanho da colônia. Assim, podemos verificar que o processo de diferenciação dessas células acontece do centro para a periferia, sendo auxiliado fisicamente pela presença da camada de sustentação (feeder layer) (Green et al., 1979; Barreca et al., 1992).

\subsection{Camada de sustentação}

O primeiro relato de utilização de células irradiadas como camada de sustentação (feeder layer), foi em um estudo desenvolvido por Puck e Markus, em 1955, no qual foi descrito o uso de células HeLa irradiadas por ortovoltagem (Raio-X). Estes autores reportaram que esta camada de sustentação fornecia fatores necessários para a formação e manutenção de colônias, desta mesma linhagem celular, porém não irradiadas. Confirmaram, também, que estas células irradiadas, além do fornecimento de fatores de crescimento, contribuíam com a presença física para a manutenção das colônias, pois as mesmas células cultivadas com meio de cultura previamente condicionado, de células HeLa não irradiadas, não promoveram uma formação e manutenção efetiva de colônias (Stocker \& Sussman, 1965; Namba et al., 1982).

O uso de células irradiadas como camada de sustentação é especialmente efetivo para células que apresentam dificuldades para se manter em cultura, como por exemplo, as células epiteliais humanas. Uma vez que as células irradiadas atuam como substrato para adesão celular, além de produzirem 
fatores estimuladores de crescimento e removerem toxinas do meio de cultura (Stocker \& Sussman, 1965; Namba et al., 1982).

Em 1975, Rheinwald e Green desenvolveram um método controlado de proliferação e diferenciação de células epiteliais em presença de feeder layer. Por meio deste método, os fibroblastos irradiados inibem a proliferação dos fibroblastos presentes nas culturas primárias de queratinócitos, permitindo sua propagação, in vitro, de uma maneira controlada e uniforme (Rheinwald \& Green, 1975; Parkinson \& Yeudall, 2002).

Para a obtenção dos fibroblastos como camada de sustentação, Rheinwald e Green, utilizaram uma linhagem celular de fibroblastos murinos $(\mathrm{NIH}-$ 3T3) modificada Todaro e Green (1963), denominada 3T3-J2, servindo, desse modo, como suporte na cultura de queratinócitos (Rheinwald, 1989) No entanto, se faz necessária a irradiação dos fibroblastos murinos a fim de controlar seu crescimento e este não se apor ao crescimento das células de interesse a serem cultivadas. A dose de 60 Gy foi preconizada por estes mesmos autores como suficiente para inibir a duplicação dos fibroblastos (Rheinwald \& Green, 1975) Posteriormente, outros métodos indicaram a utilização do tratamento de Mitomicina $\mathrm{C}$ e $\mathrm{H}_{2} \mathrm{O}_{2}$ para inibir o crescimento dos fibroblastos, com o objetivo de utilizar os mesmos como camada de sustentação (Rheinwald, 1989; Tenchini et al, 1992; Maas-szabowski et al., 1999; Sun et al., 2008).

Rheinwald e Green estudaram a possibilidade de utilização de outras linhagens celulares irradiadas, como camada de sustentação para o crescimento de queratinócitos, no entanto, estes estudos não se mostraram eficazes (Green et al., 1977; Rheinwald \& Green, 1989). Em 1989, Limat e colaboradores, desenvolveram uma técnica baseada no método supracitado, porém utilizando fibroblastos humanos irradiados, provenientes da derme, como camada de sustentação para cultura de queratinócitos em baixa densidade. Neste estudo, Limat e colaboradores, observaram a existência de vantagens no uso dos fibroblastos humanos com este objetivo, verificando que após incubação por até quatro semanas, esta camada não perdia sua eficiência de sustentação, além de apresentar maior reprodutibilidade (Limat et al., 1989; Waelti et al., 1992). Entretanto, quando Rheinwald e Green, em 1975, padronizaram esta técnica, haviam testado a utilização de fibroblastos humanos, verificando que os 
queratinócitos em cultura cresciam lentamente, em relação à cultura com camada de sustentação de fibroblastos murinos.

Além de constituírem a camada de sustentação, os fibroblastos irradiados, produzem fatores de crescimento (Barreca et al, 1992; De Luca \& Cancedda, 1992; Waelti et al., 1992; Maas-szabowski \& Fusenig, 1996; Maasszabowski et al., 1999, Nolte et al., 2008) e proteínas da matriz extracelular ao meio de cultura, facilitando a adesão e crescimento dos queratinócitos (Alitalo et al, 1982; De Luca \& Cancedda, 1992; Cristovam et al., 2008) (TAB. 1). Quando esta relação entre camada de sustentação e queratinócitos é otimizada, percebese uma melhora do crescimento e diferenciação destes últimos (Rheinwald \& Green, 1975; Green et al., 1977; Barreca et al, 1992).

TABELA 1: Moléculas sintetizadas pelos fibroblastos irradiados que auxiliam o desevolvimento dos queratinócitos em cultura.

\begin{tabular}{|c|c|}
\hline Molécula & Função \\
\hline $\begin{array}{c}\text { Laminina e colágeno } \\
\text { tipo IV }\end{array}$ & $\begin{array}{l}\text { Proteínas da matriz extracelular que auxiliam na } \\
\text { adesão e na migração das células epiteliais (Alitalo } \\
\text { et al, 1982; Cristovam et al., 2008). }\end{array}$ \\
\hline $\begin{array}{l}\text { KGF (fator de } \\
\text { crescimento de } \\
\text { queratinócitos) }\end{array}$ & $\begin{array}{l}\text { Age especificamente em células epiteliais, } \\
\text { promovendo a proliferação, inibição da apoptose e } \\
\text { evitando a diferenciação dos queratinócitos (Xiao et } \\
\text { al., 2008). }\end{array}$ \\
\hline $\begin{array}{l}\text { TGF- } \beta \text { (fator } \\
\text { transformador de } \\
\text { crescimento) }\end{array}$ & $\begin{array}{l}\text { Exerce efeito inibitório sobre a proliferação dos } \\
\text { queratinócitos, induzindo a diferenciação; apoptose } \\
\text { e síntese de colágeno tipo IV e VII (Wong et al., } \\
\text { 2007; Nolte et al., 2008). }\end{array}$ \\
\hline $\begin{array}{l}\text { IGF-I (fator de } \\
\text { crescimento semelhante à } \\
\text { insulina tipo 1) } \\
\end{array}$ & $\begin{array}{l}\text { Sinaliza aos queratinócitos a migrarem, proliferarem } \\
\text { e aumentarem a síntese de colágeno (Barreca et al, } \\
\text { 1992; Schwartz-arad et al. Apud Maia, 2008). }\end{array}$ \\
\hline IL-6 (interleucina 6) & $\begin{array}{l}\text { Exerce efeitos mitogênicos sobre os queratinócitos } \\
\text { (Waelti et al., 1992; Maas-szabowski \& Fusenig, } \\
\text { 1996; Maas-szabowski et al., 1999, Xiao et al., } \\
\text { 2008). }\end{array}$ \\
\hline IL-8 (interleucina 8) & $\begin{array}{l}\text { Promove o crescimento e a proliferação dos } \\
\text { queratinócitos (Xiao et al., 2008). }\end{array}$ \\
\hline
\end{tabular}




\subsection{Radiação ionizante}

A radiação ionizante é definida como uma forma de radiação que tem energia suficiente para atravessar e arrancar elétrons de átomos neutros ou moléculas de forma a convertê-los em íons, e assim modificando-lhes o comportamento químico Existem duas formas da radiação se propagar: corpuscular e eletromagnética (Okuno,1998).

- Radiação corpuscular é constituída de um feixe de partículas elementares, ou núcleos atômicos, tais como: elétrons, prótons, nêutrons, partículas $\alpha$ (alfa) e $\beta$ (beta) (Okuno,1998). Sendo estas obtidas pela desintegração radioativa de isótopos ou por equipamentos específicos no caso de partículas $\beta$ ou pósitrons (Silverman, 1991)

- Radiação eletromagnética é constituída de campos elétricos e magnéticos oscilantes que se propagam no vácuo com a velocidade da luz (Okuno,1998). São exemplos de ondas eletromagnéticas os raios $\gamma$ (gama), obtidos de radioisótopos, e raios $\mathrm{X}$, gerados por maquinários (Dahlan, 2001).

Os radioisótopos, também conhecidos como isótopos radioativos ou radionuclídeos ocorrem naturalmente, mas podem ser produzidos artificialmente em um reator nuclear. Estes isótopos radioativos são elementos instáveis que tem excesso de nêutrons ou prótons em seu núcleo e emitem radiações como forma de desintegração espontânea ou decaimento a um estado estável. O tempo que um radioisótopo leva para decair para metade do nível de radioatividade original é denominado meia-vida do radioisótopo, sendo específica para cada radioisótopo (Darlan, 2001, Colli \& Mesquita, 2002, CNEN, 2010).

Atualmente, o Cobalto-60 e o Césio-137 são os radioisótopos utilizados comercialmente na esterilização de materiais cirúrgicos, na conservação de alimentos e na erradicação ou controle de insetos na agricultura entre outros. Sendo que o Cobalto-60 é a fonte industrial de radiação $\gamma$ mais utilizada devido a sua alta energia quando comparada a do Césio-137 (Okuno 1988; IAEA, 2005). 


\subsubsection{Efeitos biológicos da radiação}

Existem dois efeitos pelos quais a radiação ionizante pode lesar uma molécula: o direto e o indireto. No efeito direto, a radiação age diretamente sobre as moléculas biológicas causando ionização e excitação. Na ionização, o elétron é arrancado do átomo e na excitação o elétron absorve energia passando a uma órbita mais energética. Após esta fase, as ligações químicas das moléculas são rompidas formando os radicais livres que se ligam as proteínas, as enzimas ou moléculas de DNA danificando-as (IAEA, 2010; Okuno,1998). Estima-se que um terço dos danos biológicos causados pela radiação $\gamma$ é resultante do efeito direto (IAEA, 2010). No efeito indireto, a radiação interage com as moléculas da água, principal constituinte do corpo humano e da célula, formando espécies altamente reativas como $\mathrm{OH} \cdot, \mathrm{H}$, elétron aquoso e outros (IAEA, 2010; Colli \& Mesquita, 2002; Okuno,1998). Estes, ao atacarem biomoléculas importantes das células podem causar danos irreparáveis (Colli \& Mesquita, 2002).

\subsubsection{Irradiador de Cobalto-60}

O cobalto-60 utilizado nas fontes de irradiação é produzido a partir do cobalto-59, isótopo estável, sendo formado por uma reação de captura de 1 nêutron. 0 cobalto-60 decai a níquel-60 estável por emissão de uma partícula $\beta$ negativa, com energias de 0,313 MeV, e dois fótons, com energias de 1,17 e $1,33 \mathrm{MeV}$, sendo estes os responsáveis pelo processamento dos materiais por irradiação nos irradiadores gama (ATOMIC ENERGY OF CANADA LIMITED, 1968).

A meia-vida do cobalto-60 é de 5,261 anos, portanto havendo uma redução de $12,34 \%$ da sua atividade, ao ano (IAEA, 2005).

O irradiador Gammacell-220, do Centro de Tecnologia das Radiações do Instituto de Pesquisas Energéticas e Nucleares (CTR, IPEN/CNEN-SP), possui 35 lápis de cobalto-60 de $20 \mathrm{~cm}$ de altura que circundam internamente a câmara primária totalmente isolada. Este tipo de disposição do material radioativo proporciona uniformidade de dose numa altura de $10 \mathrm{~cm}$ do material, já a região superior e inferior do cilindro recebe uma dose 15\% menor. As amostras são acondicionadas na câmara de irradiação, que possui dimensões limitadas a altura de $20,47 \mathrm{~cm}$ e diâmetro de $14,49 \mathrm{~cm}$, com volume total de 3,9 litros. A câmara de irradiação se desloca verticalmente até a meia altura da fonte, por um mecanismo 
eletro-mecânico tipo gaveta numa velocidade de 2,8 seg. Na câmara de irradiação podem ser colocados atenuadores de dose, de chumbo, com diferentes espessuras para 50\%, 70\% e 90\% de atenuação (FIG. 4) (ATOMIC ENERGY OF CANADA LIMITED, 1968).

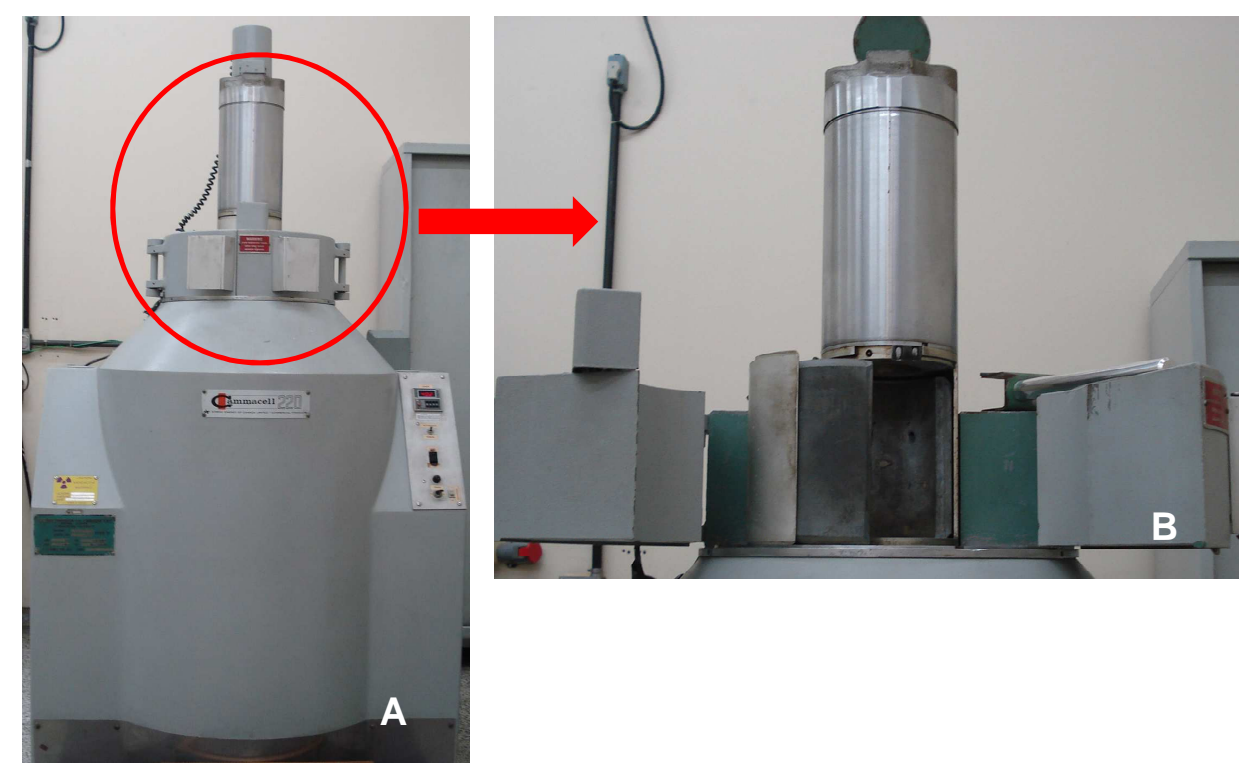

FIGURA 4: (A) Irradiador de Cobalto-60 Gammacell 220. (B) Câmara de irradiação, local onde as amostras são acondicionadas.

\subsection{Substitutos ao Soro Fetal Bovino no meio de cultura}

Atualmente existem diversas alternativas ao uso do soro fetal bovino no meio de cultura, dentre elas destacam-se os meio quimicamente definidos. No entanto, estes meios necessitam da adição de componente de origem animal como albumina, transferrina ou extrato pituitário de origem bovina, para proporcionarem melhor adesão e crescimento celular. Outras alternativas são os substitutos de origem não animal, como: extrato de planta, denominado soro vegetal; soro humano e mais recentemente o lisado de plaquetas. Este último tem sido introduzido com sucesso para crescimento e manutenção de células epiteliais em cultura (Brunner et al., 2010; Coolen et al., 2010). 


\subsubsection{Plaquetas}

As plaquetas são as menores células sanguíneas, possuem formato discóide, de 3-4 $\mu \mathrm{m}$ de tamanho e cerca $1 \mu \mathrm{m}$ de espessura. A quantidade média de plaquetas presente em um indivíduo é de 1,5 a $3,0 \times 10^{5} / \mathrm{mL}$ de sangue (Lorenzi, 2006; Young et al., 2007).

As plaquetas são fragmentos citoplasmáticos anucleados formados a partir de megacariócitos, células poliplóides, sintetizados na medula óssea durante um processo denominado megacariocitopoiese (Italiano, \& Shivdasani, 2003) Na megacariocitopoiese, o megacarioblasto, precursor do megacariócito, surge por meio de diferenciação da célula-tronco hematopoiética. Posteriormente, o megacariócito sofre endomitose, processo no qual ocorre replicação do DNA sem a divisão do citoplasma. Nesta etapa acontece maturação dos megacariócitos, com posterior expansão, dando origem à formação de extensões pró-plaquetárias, das quais as plaquetas são liberadas, durante esta ação cada megacariócito é capaz de produzir cerca de 4 mil plaquetas (Italiano \& Shivdasani, 2003; Hoffbrand et al., 2004; Zago et al.; 2004).

Após liberadas, as plaquetas são capturadas pelo baço, depósito de cerca de $30 \%$ da massa plaquetária, por um período de 24 a 48 horas. As plaquetas possuem meia de vida de aproximadamente 10 dias na circulação sanguínea, após, aquelas que não foram consumidas no processo de hemostasia, são removidas da circulação sanguínea pelos macrófagos (Zago et al.; 2004, Lorenzi, 2006).

\subsubsection{Estrutura das plaquetas}

As plaquetas apresentam uma região periférica, o hialômero, e uma região central, o granulômero. Estas regiões contêm grandes quantidades de material mucopolissacarídeo e glicoprotéico, essenciais no desempenho das funções de adesão e agregação plaquetária (Lorenzi, 2006; Gartner \& Hiatt, 2007). Apresenta uma membrana plasmática de bicamada fosfolipídica assimétrica. São encontrados na parte interna fosfatidiletanolaminas, fosfatidilserinas e fosfatidilinositol, enquanto que na parte externa encontra-se a esfingomielina. Entretanto, o principal componente encontrado é o colesterol. Sendo que, esta alta concentração de colesterol e a sua relação com os ácidos graxos saturados e os componentes fosfolipídicos influenciam diretamente na 
fluidez da membrana plasmática (Mcnicol \& Gerrard, 1997). Sua membrana possui numerosas moléculas receptoras e um revestimento externo amorfo e espesso (15 a $20 \mathrm{~nm}$ ), composto de glicoproteínas, denominado glicocálix (Mcnicol \& Gerrard, 1997; Gartner \& Hiatt, 2007). As glicoproteínas GP I, II e III (e suas variantes, como a lb, Illa e etc.) presentes no glicocálix, são de extrema importância na ativação e na agregação plaquetária (Mcnicol \& Gerrard, 1997).

No interior do hialômero existem em média 10 a 15 microtúbulos paralelos uns aos outros constituindo um anel contrátil, denominado citoesqueleto, que contém actina e miosina em sua composição. Estes microtúbulos auxiliam na manutenção do formato discóide das plaquetas. Enquanto que o citoesqueleto, também composto de um sistema tubular denso, exerce papel importante na ativação plaquetária, secreção granular e na retração do coágulo (FIG. 5) (Rendu \& Brohard-bohn, 2001; Everts et al., 2006; Gartner \& Hiatt, 2007).

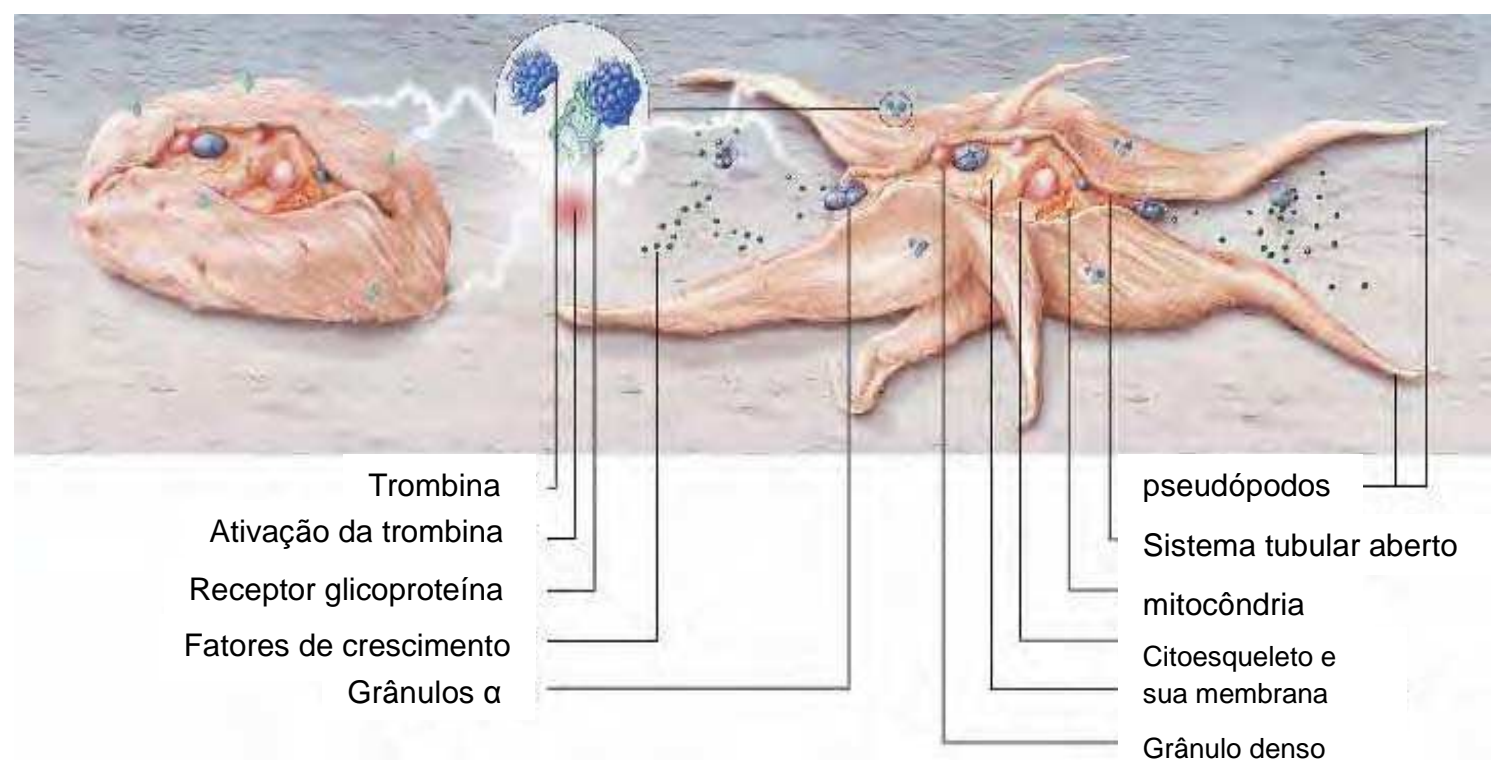

Figura 5 - Visão esquemática das plaquetas em repouso e quando ativadas. (modificada de Everts et al., 2006).

Normalmente as plaquetas estão em repouso. $\mathrm{Na}$ ativação (por exemplo, pela trombina), as plaquetas alteraram a sua forma com o desenvolvimento de pseudópodos para promover a agregação plaquetária e posterior liberação do conteúdo dos grânulos (Everts et al., 2006). 
Além do sistema tubular denso, existe o sistema aberto para superfície (desconexão) também presente no hialômero. O sistema aberto para superfície é um sistema de comunicação com o meio externo e composto por canais enovelados e entrelaçados que constituem um complexo emaranhado no interior da plaqueta (Gartner \& Hiatt, 2007). O sistema tubular denso tem como função armazenar o cálcio intracelular e sua estrutura é composta de restos do retículo endoplasmático que não se comunicam com o meio externo (Mcnicol \& Gerrard, 1997).

$\mathrm{Na}$ ultra-estrutura do granulômero, as plaquetas contêm um pequeno número de mitocôndrias, depósitos de glicogênio, peroxissomas e possuem três tipos de organelas secretoras: corpos densos, grânulos alfa e lisossomas (King \& Reed, 2002; Gartner \& Hiatt, 2007). O granulômero também abrange um sistema composto de enzimas que permite que as plaquetas realizem processos como catálise do glicogênio, consumo de oxigênio e geração de energia, via ATP (Gartner \& Hiatt, 2007).

Os corpos densos são constituídos principalmente de adenosina difosfato (ADP) e adenosina trifosfato (ATP) que representam uma porção de $65 \%$ nas plaquetas. Contém também serotonina, pirofosfatase e histamina, que quando em baixa concentração, promovem alterações na propriedade de agregação das plaquetas e cálcio, que é responsável por conferir a estrutura densa a estes corpos (Zago et al. 2004; Lorenzi, 2006).

Os grânulos alfa ( $\alpha$ ) são os maiores $(200-500 \mathrm{~nm})$ e os mais abundantes grânulos secretores encontrados nas plaquetas (King \& Reed, 2002). Contêm moléculas de adesão importantes para a interação plaqueta-plaqueta, também possuem fatores mitogênicos, proteínas plasmáticas e fatores relevantes para a coagulação e fibrinólise, tais como: fatores de crescimento $(P D G F=$ fator de crescimento derivado de plaquetas; fator plaquetário 4 ; TGF- $\beta=$ fator transformador de crescimento $\beta$ ), fatores de coagulação (fator $V$; fibrinogênio, fator VIII R; proteína S), e proteínas de adesão (fibronectina; trombospondina; vWf = fator Von Willebrand; vitronectina) que encontram-se presentes em altas concentrações no local de lesão vascular, auxiliando na formação do trombo plaquetário (Zago et al. 2004; Lorenzi, 2006; Gartner \& Hiatt, 2007; Zarbock et al., 2007). Estes fatores em conjunto facilitam a agregação plaquetária, o reparo 
tecidual e a coagulação sanguínea (Rendu \& Brohard-Bohn, 2001; Lorenzi, 2006; Gartner \& Hiatt, 2007).

Quanto aos grânulos lisossômicos, estes apresentam enzimas hidrolíticas, as glicosidases, proteases e proteínas catiônicas. Estas enzimas auxiliam na reabsorção do coágulo, digerindo material restante dos agregados das plaquetas (Rendu \& Brohard-Bohn, 2001; Gartner \& Hiatt, 2007).

No entanto, os grânulos supracitados possuem propriedades específicas, estando relacionadas com a estrutura e o conteúdo liberado por estes. As plaquetas carreiam e liberam estes grânulos na circulação quando estimuladas por reações do organismo. Essa reação de secreção dos grânulos, bem como seu conteúdo, integra uma importante etapa para o que se denomina hemostase. A mitocôndria e o sistema tubular denso também contribuem para a execução desta etapa no fornecimento de energia para a reatividade plaquetária (Rendu \& Brohard-Bohn, 2001). Além disso, a mitocôndria apresenta grande importância nesta fase, visto que atua na síntese de ATP, essencial para o bom funcionamento da plaqueta (Lorenzi, 2006). As plaquetas ativadas utilizam energia na forma de ATP essenciais para a secreção, contração e alteração na forma celular. Esta energia pode ser obtida por meio do metabolismo da glicose, seja por glicólise anaeróbia ou por fosforilação oxidativa nas mitocôndrias. As plaquetas não ativadas também fazem uso de energia via ATP para manutenção de suas propriedades de bombeamento de sódio para o meio extracelular, polimerização e despolimerização da actina (Ávila, 1997).

\subsubsection{Heparina}

Em 1916, Jay McLean, estudante de medicina do Hospital Johns Hopkins, Baltimore, EUA, descobriu acidentalmente a heparina, substância anticoagulante. A substância foi encontrada enquanto o estudante, durante um projeto, tentava extrair substâncias tromboplásticas, isto é, coagulantes, de vários tecidos, e ao contrário disso, descobriu uma substância com potente atividade anticoagulante. A heparina foi assim denominada, devido sua extração inicial ter ocorrido no fígado (Rang et al., 2004). 
A heparina, do ponto de vista químico, é uma miscelânea de moléculas altamente eletronegativas de ácidos mucopolissacarídeos sulfatados (FIG. 6), que constitui o ácido macromolecular mais potente existente no organismo, apresentando peso molecular que varia de 7.000 a 40.000 dáltons (Pereira, 2002; Rang et al., 2004; Souza \& Elias, 2006).

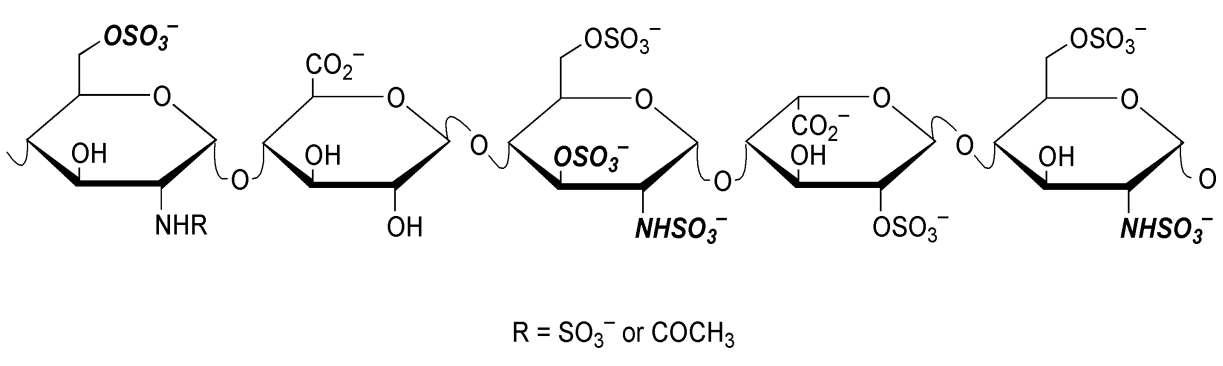

FIGURA 6 - Estrutura molecular da heparina (Rabenstein, 2002).

A heparina pode ser encontrada, em abundância nos pulmões, fígado e, principalmente, nos mastócitos do sistema retículo-endotelial. A síntese da heparina ocorre nos mastócitos a partir de precursores de UDP-açúcar, ácido Dglicurônico e N-acetil-D-glicosamina (Pereira 2002; Majerus \& Tollefsen, 2006; Souza \& Elias, 2006).

\subsubsection{Mecanismo de ação da Heparina}

A heparina é responsável por inibir a coagulação sanguínea, seja in vivo ou in vitro, por meio da inibição de várias proteases da coagulação ao ativar a antitrombina III. A antitrombina III é uma glicoproteína presente no plasma, e denominada "substrato suicida" das proteases, pois atua inibindo a trombina e outras serinas-proteases ao ligar-se ao sítio ativo da serina, desta formas as proteases atacam esta ligação ficando retidas e assim formando um complexo 1:1 estável (Rang et al., 2004; Majerus \& Tollefsen, 2006; Souza \& Elias, 2006).

A trombina, fator II ativado, proveniente da conversão da protrombina (fator II) por ação enzimática, é responsável por converter o fibrinogênio em fibrina além de ativar os co-fatores $\mathrm{V}$ e VIII formando assim a coagulação. No entanto a heparina atua inibindo a trombina, impedindo a conversão de 
fibrinogênio em fibrina e, por conseguinte a coagulação (FIG. 7) (Rang et al., 2004; Majerus \& Tollefsen, 2006; Souza \& Elias, 2006).

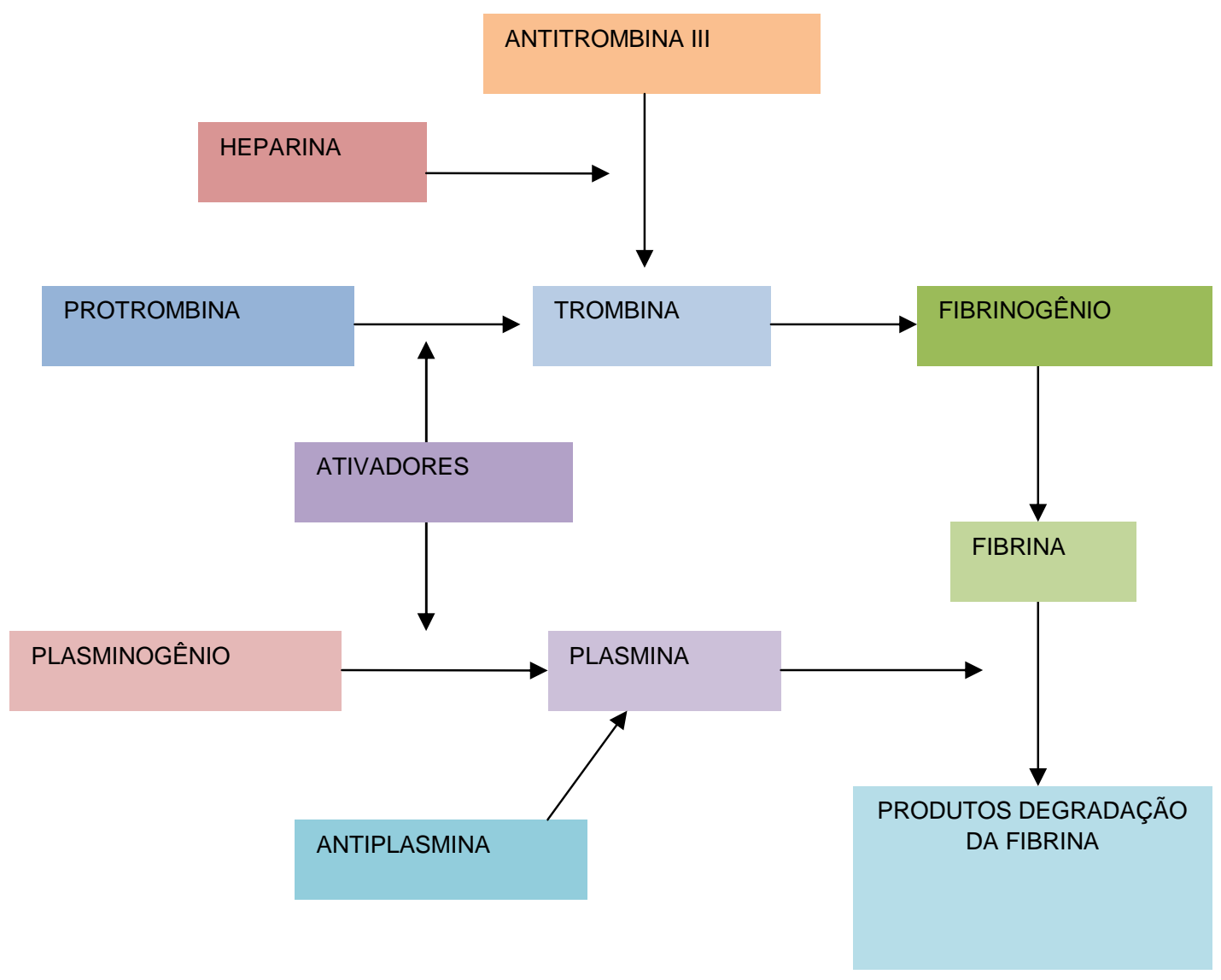

FIGURA 7 - Diagrama do mecanismo de coagulação, mostrando a ação da heparina sobre a antitrombina III, que impede a conversão de fibrinogênio em fibrina (Souza \& Elias, 2006).

O complexo heparina-antitrombina III é responsável por inibir a trombina e o fator $X$, no entanto a trombina é mais sensível a este efeito de inibição do que o fator $X$. O fator $X$, ou fator Stuart-Prower, é uma proteína que integra os fatores de coagulação. Para inibir a trombina, a heparina e a antitrombina III necessitam se ligar a ela, porém para inibir o fator $X$ ativado (fator Xa), a heparina necessita se ligar apenas à antitrombina III (Rang, et al., 2004). 
As heparinas de baixo peso molecular (Low Molecular Weight Heparine - LMWH) atuam aumentando a ação da antitrombina III sobre o fator X. No entanto, quanto à inibição da trombina, as moléculas de alto peso molecular atuam mais efetivamente que as $\mathrm{LMWH}$, visto que estas são demasiado pequenas para se ligarem tanto a enzima trombina quanto ao inibidor (FIG. 8) (Rang, et al., 2004).

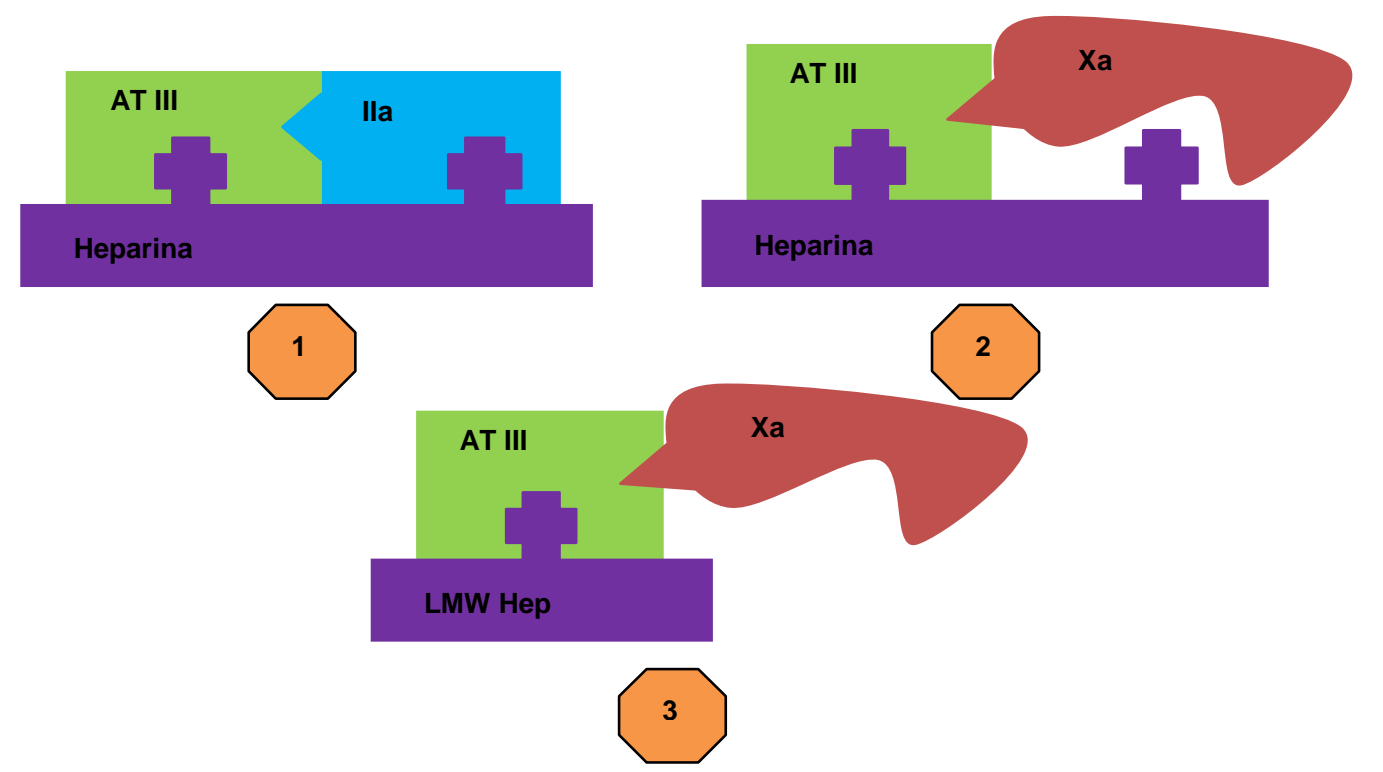

FIGURA 8 - Ação das heparinas. Desenho esquemático representando as interações de heparinas, antitrombina III (AT III) e fatores de coagulação. Para aumentar a inativação da trombina (Ila) pela AT III, a heparina precisa interagir com ambas as substâncias (1); entretanto, para acelerar seu efeito sobre o fator $X$ ativado (Xa), a heparina precisa apenas interagir com a AT III (2). As heparinas de baixo peso molecular (LMW Hep) aumentam a ação da AT III sobre o fator X (3), mas não podem aumentar a ação da AT III sobre a trombina, visto que são incapazes de ligar-se a ambos simultaneamente. (modificado de Rang, et al., 2004) 


\subsubsection{Lisados de Plaquetas}

Ross, em 1974, ao cultivar fibroblastos derivados da derme e células da musculatura lisa, em meio de cultura contendo plasma pobre em plaquetas, constatou que este meio não proporcionava uma proliferação semelhante quando comparada com meio contendo apenas soro. Porém, ao adicionar fatores de crescimento obtidos da lise das plaquetas, atualmente denominado lisado de plaquetas, no meio contendo plasma, observou a ocorrência de uma melhora na proliferação celular quando comparada com meio contendo somente soro (Ross et al., 1974; Eastment \& Sirbasku, 1980).

Posteriormente, diversos estudos foram realizados, a fim de avaliar o comportamento do meio de cultura contendo fatores de crescimento derivados de plaquetas em diversas linhagens celulares, nos quais foi observado que as plaquetas proporcionam uma potente fonte mitogênica. Sendo assim, constatouse que a utilização do meio contendo plaquetas confere às células melhor crescimento e proliferação celular (Eastment \& Sirbasku, 1980).

Sabe-se que as plaquetas, importantes no reparo tissular, são carreadoras de citocinas e fatores de crescimento, e quando ativadas, por exemplo, pela trombina, liberam esses fatores que proporcionam o crescimento e a proliferação celular, auxiliando desta forma, no processo de cicatrização (Johansson et al., 2003; Castro et al., 2006, Mirabet et al., 2008).

A utilização de plaquetas in vitro, no cultivo de células, é importante para proporcionar melhor crescimento celular. Estas plaquetas são utilizadas na forma de lisado, em substituição ao uso de soro animal, soro fetal bovino, uma vez que esta é uma alternativa na humanização da cultura celular (Mirabet et al., 2008; Blande et al., 2009).

As plaquetas, utilizadas para este fim, são provenientes de bolsas de concentrado de plaquetas de diversos doadores ou do próprio paciente. Estas bolsas são submetidas a ciclos de congelamento e descongelamento para que ocorra a lise das plaquetas e, por conseguinte a liberação de fatores de crescimento. Outro método de obter estes fatores é por meio da ativação das plaquetas na presença de trombina, como ocorre na cascata de coagulação in vivo. Após a obtenção deste lisado, este é filtrado e pode ser estocado a - $20{ }^{\circ} \mathrm{C}$, para posterior utilização (Schallmoser et al., 2007; Kurita et al., 2008; Blande et al., 2009, Senegaglia et al., 2009). 
Estudos recentes demonstram que a utilização de lisado de plaquetas no cultivo de células, para fins clínicos, é um método alternativo ao uso do soro fetal bovino, visto que o soro de origem animal pode transmitir príons (proteínas modificadoras de outras proteínas) e/ou vírus de origens diversas ao humano, ocasionando doenças como zoonoses, viroses animais e a Encefalopatia Espongiforme Bovina (EEB) (Mannello \& Tonti, 2007; Sun et al., 2004). A humanização de cultura celular visa tanto a preocupação de transmissão de patógenos de origem animal ao humano, quanto a segurança de animais utilizados em pesquisa, visto que atualmente, entidades protetoras dos animais, têm discutido e criticado procedimentos severos para a obtenção do soro animal, como a punção cardíaca no feto bovino (Álden et al., 2007, Brunner et al., 2010).

\subsubsection{Fatores de Crescimento contidos no lisado de plaquetas}

Os fatores de crescimento são peptídeos sinalizadores que regulam o metabolismo celular. Eles podem ser classificados como morfométricos, atuando no crescimento ósseo, e mitogênicos, envolvidos no aumento da produção de células cicatriciais (Everts et al., 2006). Os principais fatores de crescimento envolvidos na degranulação plaquetária são TGF- $\beta$ (fator transformador de crescimento), PDGF (fator de crescimento derivado de plaqueta), EGF (fator de crescimento epidérmico), VEGF (fator de crescimento endotélio vascular), bFGF (fator de crescimento fibroblástico básico), CTGF (fator de crescimento de tecido conjuntivo) e também estão presentes a tromboplastina plaquetária, fibrinogênio, cálcio, serotonina e enzimas hidrolíticas (Everts et al., 2006; Harrison \& Cramer, 1993). Na TAB. 1, podemos visualizar um resumo da origem e função de cada um destes fatores de crescimento. 
Tabela 2: Fatores de crescimento, origem e funções (modificado de EVERTS, 2006)

\begin{tabular}{|c|c|c|}
\hline $\begin{array}{l}\text { Fatores de } \\
\text { Crescimento }\end{array}$ & Origem & Função \\
\hline TGF- $\beta$ & $\begin{array}{l}\text { Plaquetas, matriz } \\
\text { óssea extracelular, } \\
\text { matriz } \\
\text { cartilaginosa, } \\
\text { células Natural } \\
\text { Killer (NK), } \\
\text { macrófagos, } \\
\text { neutrófilos e } \\
\text { monócitos. }\end{array}$ & $\begin{array}{l}\text { Estimula a proliferação de células } \\
\text { mesenquimais indiferenciadas; regula a } \\
\text { mitogênese do endotélio, osteoblasto e } \\
\text { fibroblasto; regula a síntese de } \\
\text { colágeno e a secreção de colagenase; } \\
\text { regula os efeitos mitogênicos de outros } \\
\text { fatores de crescimento; estimula a } \\
\text { quimiotaxia endotelial e angiogênese; } \\
\text { inibe a proliferação dos macrófagos e } \\
\text { linfócitos }\end{array}$ \\
\hline PDGF & $\begin{array}{l}\text { Plaquetas, } \\
\text { osteoblastos, } \\
\text { células endoteliais, } \\
\text { macrófagos, } \\
\text { monócitos e } \\
\text { células do músculo } \\
\text { liso }\end{array}$ & $\begin{array}{l}\text { Mitogenética de células mesenquimais } \\
\text { e osteoblastos; estimula a quimiotaxia e } \\
\text { mitogênese em fibroblastos, células } \\
\text { gliais e do músculo liso; regula a } \\
\text { síntese de colágeno e secreção de } \\
\text { colagenase; estimula a quimiotaxia dos } \\
\text { macrófagos e neutrófilos }\end{array}$ \\
\hline EGF & $\begin{array}{l}\text { Plaquetas, } \\
\text { macrófagos e } \\
\text { monócitos }\end{array}$ & $\begin{array}{l}\text { Estimula a quimiotaxia endotelial / } \\
\text { angiogênese; regula a secreção de } \\
\text { colagenase; estimula a mitogênese das } \\
\text { células epiteliais e mesenquimais }\end{array}$ \\
\hline VEGF & $\begin{array}{l}\text { Plaquetas e } \\
\text { células endoteliais }\end{array}$ & $\begin{array}{lll}\text { Aumenta a angiogênese e a } & \text { a } \\
\text { permeabilidade do vaso; estimula a } \\
\text { mitogênese de células endoteliais }\end{array}$ \\
\hline bFGF & $\begin{array}{l}\text { Plaquetas, } \\
\text { macrófagos, } \\
\text { células } \\
\text { mesenquimais, } \\
\text { condrócitos e } \\
\text { osteoblastos } \\
\end{array}$ & $\begin{array}{l}\text { Promove o crescimento e diferenciação } \\
\text { dos condrócitos e osteoblastos, } \\
\text { mitogenética de células mesenquimais, } \\
\text { condrócitos e osteoblastos }\end{array}$ \\
\hline CTGF & $\begin{array}{l}\text { Plaquetas através } \\
\text { de endocitose do } \\
\text { meio extracelular } \\
\text { da medula óssea }\end{array}$ & $\begin{array}{l}\text { Promove a angiogênese, a regeneração } \\
\text { da cartilagem, fibrose e a adesão de } \\
\text { plaquetas }\end{array}$ \\
\hline
\end{tabular}




\section{MATERIAIS E MÉTODOS}

\subsection{Obtenção dos materiais biológicos}

Este trabalho obteve a aprovação do Comitê de Ética em Pesquisa da Faculdade de Saúde Pública da Universidade de São Paulo - COEP sob número 2177 ( ANEXO A).

O lisado de plaquetas utilizado neste estudo, foi obtido a partir de bolsas de concentrado de plaquetas, com o prazo de validade expirado, doadas pela Fundação Zerbini - Instituto do Coração - HCFMUSP, já submetidas a testes sorológicos como: testes específicos para síndrome da imunodeficiência adquirida (SIDA), hepatite $B$, hepatite $C$, sífilis, doença de Chagas, HTL (vírus linfotrófico de células $T$ humanas) I e II, sorologia para citomegalovírus e toxoplasmose. Tais bolsas foram mantidas congeladas a $-80^{\circ} \mathrm{C}$ até o momento do uso.

Os queratinócitos e os fibroblastos humanos foram obtidos a partir de três amostras de peles sadias, proveniente de mamoplastia, doadas pelo Banco de Tecidos do Instituto Central do Hospital das Clínicas (ICHC) da FMUSP com a finalidade de pesquisa.

Os fibroblastos murinos foram obtidos da ATCC, empresa em que o pesquisador H. Green depositou essa linhagem de células, sob o código CCL-92.

\subsection{Descarte de material biológico}

Quanto ao descarte de bolsas vazias e resíduos de material biológico (plaquetas e pele), estes foram submetidos a ação de hipoclorito de sódio por 30 minutos antes de serem descartados em saco plástico apropriado para o descarte de material infectante.

\subsection{Cultura primária de fibroblastos}

Os fibroblastos humanos foram isolados in vitro segundo a técnica de explante, proposta por Carrel \& Burrows (1910), a saber: as amostras de tecido foram cortadas em fragmentos de aproximadamente $1 \mathrm{~mm}^{2}$ e depositadas uma a uma, sobre a superfície de cultivo de frascos de $25 \mathrm{~cm}^{2}$, de maneira que a derme permanecesse em contato com a superfície de cultivo. Concluída esta etapa, foram adicionados $5 \mathrm{~mL}$ de meio de cultura para fibroblastos, a saber: Dulbecco's Modified Eagle Medium (Invitrogen 12800-058) acrescido de 4mM glutamina 
(Invitrogen 25030-081), $100 \mathrm{U} / \mathrm{mL}$ penicilina, $100 \mu \mathrm{g} / \mathrm{mL}$ estreptomicina e 0,25 $\mu \mathrm{g} / \mathrm{mL}$ anfotericina B (Invitrogen 15240-062) e de 10\% de Soro Fetal Bovino (Vitrocell S0011). As culturas foram mantidas em estufa a $37{ }^{\circ} \mathrm{C}$ em atmosfera de $5 \%$ de $\mathrm{CO}_{2}$. $\mathrm{O}$ meio de cultura foi trocado a cada $72 \mathrm{~h}$ até que um número suficiente de células tivesse migrado dos fragmentos de pele.

\subsubsection{Amplificação dos fibroblastos}

No momento em que os fibroblastos apresentaram aspecto de subconfluência ${ }^{1}$, os fragmentos dermo-epidérmicos foram descartados e foi realizada a amplificação da cultura da seguinte maneira: o frasco foi lavado com solução fisiológica e nele foram adicionados $3 \mathrm{~mL}$ de solução de $0,05 \%$ tripsina (Sigma 8540C) e 0,02\% Ácido Etilenodiaminotetracético (EDTA) (Sigma E6758). A reação enzimática foi realizada a $37^{\circ} \mathrm{C}$, até que as células se desprendessem do fundo da garrafa.

A ação da tripsina foi neutralizada com solução contendo íon cálcio e albumina $(\mathrm{v} / \mathrm{v})$. O conteúdo da garrafa de cultura foi transferido para um tubo de fundo cônico de $15 \mathrm{~mL}$ e centrifugado por 5 minutos a $1500 \mathrm{rpm}(378 \mathrm{~g})$. O sobrenadante foi descartado e o botão de células foi ressuspendido em meio de cultura, homogeneizado, contado em câmara hemocitométrica e semeado em novas garrafas. Amplificações subseqüentes foram realizadas até obtenção do número necessário de células para a realização dos experimentos.

A seguir na FIG. 9 é mostrada a cultura primária dos fibroblastos humanos obtido pela técnica de explante.
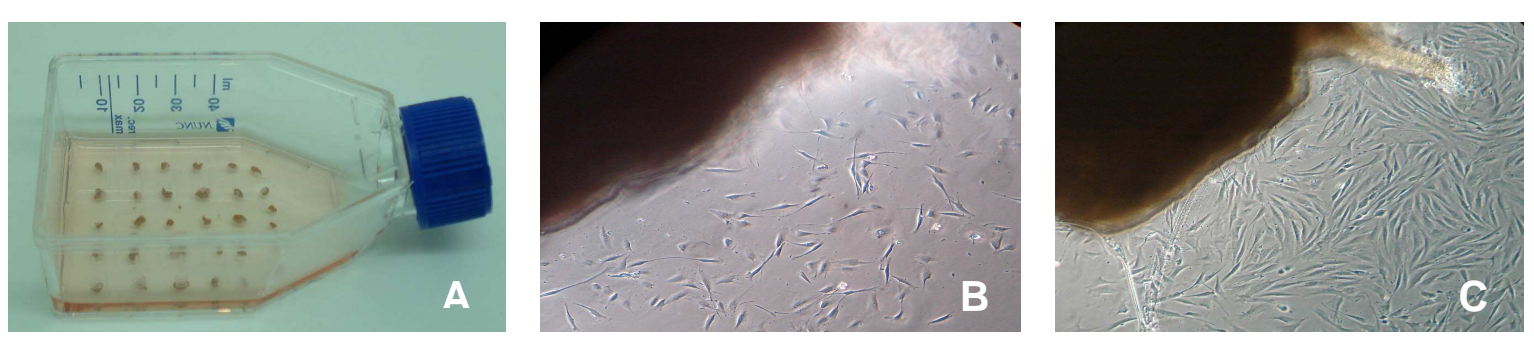

FIGURA 9 - Cultura primária dos fibroblastos humanos. (A) Frasco de cultura contendo os fragmentos de pele. (B) Imagem microscópica dos fibroblastos migrando a partir do fragmento de pele. (C) Imagem microscópica dos fibroblastos apresentando aspecto de subconfuência. Aumento de 100 vezes, visualizadas com filtro azul.

\footnotetext{
${ }^{1} \mathrm{NA}$ : aspecto de subconfluência $=$ aspecto de $70-80 \%$ da confluência celular em torno ao fragmento
} 


\subsection{Preparo do lisado de plaquetas (LP) para o teste de heparina}

$O$ lisado de plaquetas foi preparado a partir de três bolsas de concentrado de plaquetas do tipo sanguineo $\mathrm{A}_{+}$, com aproximadamente $8,5 \times 10^{8}$ plaquetas $/ \mathrm{mL}$. Inicialmente o conteúdo de cada bolsa foi dividido em triplicata e armazenado em embalagens duplas de poly-nylon. Obtivemos assim, as seguinte amostras: A1, B1, C1 (correspodentes a bolsa 1); A2, B2, C2 (correspodentes a bolsa 2) e A3, B3, C3 (correspodentes a bolsa 3 ). Sendo que nas amostras A1, B1, A2, B2, C1, C2 foi adicionada heparina (Hemofol®), na concentração de $100 \mathrm{Ul} / \mathrm{mL}$. Em seguida tanto as mostras heparinizadas como as não heparinizadas foram congeladas por 6 horas a $-80 \stackrel{\circ}{\mathrm{C}}$ e descongeladas a $37 \stackrel{\circ}{\mathrm{C}}$. Esse procedimento foi repetido 4 vezes para garantir que todas as plaquetas fossem lisadas. O conteúdo de cada amostra foi então distribuído em tubos cônicos (50 mL) e centrifugados a $3615 \mathrm{~g}$ por 30 minutos (Blande et al., 2009). Após a centrifugação, o sobrenadante foi recolhido e este processo foi repetido por 3 vezes. Os sobrenadantes finais de A1, A2 e A3 foram combinados, obtendo assim o lisado de plaquetas $A$, o mesmo procedimento foi realizado com as outras amostras, obtendo assim os lisados de plaquetas B e C. Todos os lisados foram então pré-filtrados em membranas de nylon com poros de $100 \mu \mathrm{m}$, para remoção dos materiais suspensos. Na etapa final, cada solução foi passada em filtros de $0,45 \mu \mathrm{m}$ (Millipore SCHVU05RE) sob pressão negativa e estocada - $20 \stackrel{\circ}{\mathrm{C}}$ até $\mathrm{o}$ momento do uso.

Para padronizar o número de ciclos de congelamento e descongelamento, além da eficiência da adição, ou não, de heparina nesta fase de lise, foi verificada a presença de agregados na superfície, suspensões e botão celular (FIG. 10).
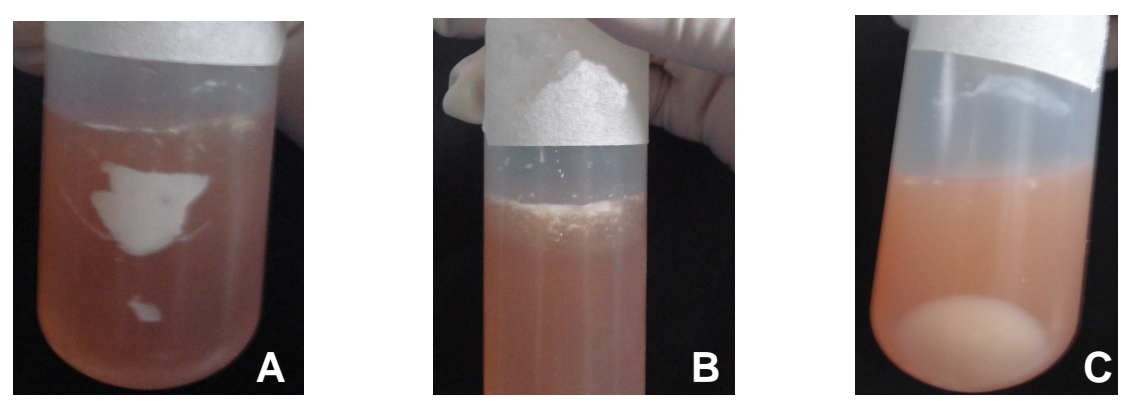

FIGURA 10 - Imagens dos lisados de plaquetas durante os ciclos de centrifugação. (A) agregados na superfície. (B) suspensões. (C) botão celular. 


\subsubsection{Preparo dos meios de cultura contendo lisados de plaquetas}

O preparo do meio de cultura contendo lisado de plaquetas é semelhante ao meio padronizado para o cultivo de fibroblastos (vide item 4.3), porém houve a substituição do soro fetal bovino $10 \%$ pelos lisados de plaquetas $A, B$ e C (LPA, LPB e LPC, respectivamente). Sendo que nos meios contendo os lisados $A$ e $C$ foram adicionados mais $2 \mathrm{UI}$ de heparina/mL de meio.

\subsubsection{Ensaio de proliferação dos fibroblastos humanos em meio de cultura suplementado com lisado de plaquetas}

Em placas multipoços de 12 poços foram semeados $1 \times 10^{4}$ fibroblastos humanos por poço, recém tripsinizados e contados em câmara hemocitométrica, em meios de culturas suplementados com: 10\% de SFB, ou $10 \%$ de LPA, ou $10 \%$ de LPB ou $10 \%$ de LPC. As placas foram incubadas em estufa a $37{ }^{\circ} \mathrm{C}$ em atmosfera de $5 \%$ de $\mathrm{CO}_{2}$. Os meios de cultura foram trocados a cada 72 horas. Nos momentos 24 h, 48 h, 72 h, 96 h e 120 h, as células foram destacadas da superfície de cultivo e contadas em câmara hemocitométrica. 0 teste de vitalidade celular foi realizado utilizando-se o corante transmembrana não vital tripan blue (Invitrogen 15250-061), sendo contadas separadamente, as células onde o corante não penetrou (células vivas), e onde este penetrou, tornando as células azuis (células mortas). As curvas obtidas com os meios contendo os lisados de plaquetas foram comparadas com a curva do controle (SFB) em gráficos de número de células versus tempo de cultura. A morfologia celular foi acompanhada por visualização ao microscópio óptico e registro fotográfico.

\subsubsection{Ensaio de adesão celular}

Neste ensaio foram semeados aproximadamente $1 \times 10^{4}$ fibroblastos humanos em placa de 96 poços contendo meios de cultura, variando os seguintes suplementos e suas concentrações: soro fetal bovino - SFB (10\%) (controle), soro de bezerro - CS (10\%), LPA (2,5\%; $5 \%$ e $10 \%)$, LPB $(2,5 \% ; 5 \%$ e $10 \%)$ ou LPC $(2,5 \% ; 5 \%$ e $10 \%)$. A placa foi mantida em estufa a $37{ }^{\circ} \mathrm{C}$, com $5 \%$ de $\mathrm{CO}_{2}$ por 24 horas. Decorrido este período, os meios foram retirados e adicionaram-se alíquotas de $120 \mu \mathrm{L}$ de meio de cultura com MTS/PMS (Cell Titer 96 ${ }^{\circledR}$ - Ensaio Aquoso não radioativo de proliferação celular - PROMEGA CORPORATION, 
2001), em meio próprio para fibroblastos, em todos os poços da placa, a qual foi imediatamente acondicionada em estufa por 2 horas. Após este período, foram realizadas medidas de absorbância, a $490 \mathrm{~nm}$, em espectrofotômetro com multidetetores (Molecular Devices Spectra Max 190), a cada hora, até que o controle apresentasse absorbância em torno a 1,8.

A viabilidade celular foi determinada pele relação:

$$
\operatorname{VC}(\%)=\left(\frac{\text { DOamostra }}{\text { DOcontrole }}\right) \times 100
$$

Onde: VC é viabilidade celular (\%); $\mathrm{DO}_{a m o s t r a}$ é densidade óptica da amostra; $\mathrm{DO}_{\text {controle }}$ é densidade óptica do controle (meio com SFB).

\subsubsection{Ensaio de comparação da viabilidade celular}

Este ensaio foi realizado com intuito de verificar a proliferação dos fibroblastos humanos mantidos em cultura com meios suplementados por LPA, LPB e LPC nas concentrações de 2,5\%, 5\% e 10\% e CS na concentração de $10 \%$, em relação ao controle de células cultivadas em DMEM com $10 \%$ de SFB. Para este ensaio foram semeados aproximadamente $1 \times 10^{4}$ fibroblastos humanos em meio DMEM suplementado com $10 \%$ de soro fetal bovino em placas de 96 poços e incubados em estufa a $37{ }^{\circ} \mathrm{C}$, com $5 \%$ de $\mathrm{CO}_{2}$ por 24 horas. Decorrido este período, os meios de cultura foram retirados dos poços e adicionaram-se os meios suplementados com SFB (10\%), CS (10\%), LPA $(2,5 \%$; $5 \%$ e $10 \%)$, LPB $(2,5 \% ; 5 \%$ e $10 \%)$ ou LPC $(2,5 \% ; 5 \%$ e $10 \%)$. As placas foram incubadas em estufa a $37{ }^{\circ} \mathrm{C}$ em atmosfera de $5 \%$ de $\mathrm{CO}_{2}$, com troca do meio a cada três dias. Nos intervalos de 24 h, 48 h, 72 h e 96 h de contato foram feitas as leituras das placas com adição do reagente MTS/PMS conforme descrito em 4.4.3.

Os valores encontrados foram comparados com o respectivo controle, considerando este último como $100 \%$ de proliferação para cada tempo observado.

\subsection{Preparo do lisado de plaquetas para o teste do tipo sanguíneo}

Foram descongelas 6 bolsas pré selecionadas, de cada tipo sanguíneo, todas fator $\mathrm{RH}+$, com média de $8,5 \times 10^{8}$ plaquetas $/ \mathrm{mL}$. A cada uma delas foram acrescentados $100 \mathrm{Ul} / \mathrm{mL}$ de heparina e em seguida, a exemplo do teste anterior 
(4.4), as bolsas foram submetidas a 4 ciclos de congelamento e descongelamento.

Após o último descongelamento, unificaram-se as bolsas de cada tipo sanguíneo, obtendo-se assim os seguintes lisados: lisado de plaquetas do tipo sanguíneo A (LA); lisado de plaquetas do tipo sanguíneo $B$ (LB); lisado de plaquetas do tipo sanguíneo $A B(L A B)$; e lisado de plaquetas do tipo sanguíneo $O$ (LO). Após a obtenção dos lisados de plaquetas por tipo sanguíneo, efetuou-se a combinação destes tipos sanguíneos em quantidades iguais (LPool). Posteriormente, os lisados LA, LB, LAB, LO e LPool foram armazenados, individualmente, em frascos de $500 \mathrm{~mL}$ e submetidos a 4 processos de centrifugação a $3615 \mathrm{~g}$ durante 30 minutos cada. Efetuada essa etapa, os lisados obtidos foram pré-filtrados, esterilizados e estocados conforme o item 4.4.

\subsubsection{Ensaio de adesão celular}

Foram semeados aproximadamente $1 \times 10^{4}$ fibroblastos humanos em placa de 96 poços contendo meios de cultura, variando os seguintes suplementos: SFB (10\%), CS (10\%), LA (10\%), LB (10\%), LAB (10\%), LO (10\%) LPool (10\%). A placa foi mantida em estufa a $37{ }^{\circ} \mathrm{C}$, com $5 \%$ de $\mathrm{CO}_{2}$. Após 24 horas, foi realizada a leitura das placas com adição do reagente MTS/PMS descrito em 4.4.3.

Os valores obtidos foram comparados e analisados por viabilidade celular dos meios testados, verificando-se a influência do tipo sanguíneo na adesão celular dos fibroblastos humanos.

\subsubsection{Ensaio de comparação de viabilidade celular}

Neste ensaio foram semeados aproximadamente $1 \times 10^{4}$ fibroblastos humanos em meio DMEM suplementado com $10 \%$ de soro fetal bovino em placas de 96 poços e incubados em estufa a $37{ }^{\circ} \mathrm{C}$, com $5 \%$ de $\mathrm{CO}_{2}$ por 24 horas. Decorrido este período, os meios de cultura foram retirados dos poços e foram adicionados os meios suplementados com SFB (10\%), CS (10\%), LA (10\%), LB (10\%), LAB (10\%), LO (10\%) ou LPool (10\%). As placas foram incubadas em estufa a $37{ }^{\circ} \mathrm{C}$ e atmosfera de $5 \%$ de $\mathrm{CO}_{2}$, com troca do meio a cada três dias. Nos intervalos de 24 h, 48 h, 72 h e 96 h de contato foram feitas as leituras das placas com adição do reagente MTS/PMS conforme descrito em 4.4.3. 
Os valores obtidos foram comparados para verificar a influência do tipo sanguíneo no desenvolvimento dos fibroblastos humanos nos tempos prédeterminados, sendo que cada um destes foi comparado com o controle, considerando este último como $100 \%$ de proliferação, para cada tempo observado.

\subsection{Padronização da dose de irradiação}

Os fibroblastos humanos foram expostos à fonte de irradiação de ${ }^{60} \mathrm{Co}$, tipo Gammacel-220, com taxa de dose de $567 \mathrm{~Gy} / \mathrm{h}$, para irradiação na doses de 60, 70, 100, 200, 250 e 300 Gy. Após irradiadas, as células foram semeadas em placas de cultura com 24 poços na concentração de $5 \times 10^{4}$ células/poço em meio próprio para queratinócitos denominado (K-), a saber: DMEM, F12 Nutrient Mixture (Invitrogen 11765054 ) (2:1), 10\% de soro fetal bovino, penicilina (100 U/mL), estreptomicina (100 $\mu \mathrm{g} / \mathrm{mL})$, anfotericina $B(0,25 \mu / \mathrm{mL})$, glutamina $(4 \mathrm{mM})$, adenina $(0,18 \mathrm{mM})$ (Sigma A9795), hidrocortisona $(0,4 \mu \mathrm{g} / \mathrm{mL})$ (Sigma H0396), insulina ( $5 \mu \mathrm{g} / \mathrm{mL}$ ) (Sigma I1882), toxina do cólera $(0,1 \mathrm{nM})$ (Sigma C8052), e triidotironina (20 pM) (T3 Sigma T5516). Como controle utilizamos dois grupos: um composto por fibroblastos humanos não irradiados e outro por fibroblastos murinos irradiados a $60 \mathrm{~Gy}$. As células foram incubadas em estufa a $37^{\circ} \mathrm{C}$ e atmosfera de $5 \%$ de $\mathrm{CO}_{2}$, com troca do meio a cada dois dias, sendo que a partir da primeira troca de meio, foi adicionado fator de crescimento epidérmico (EGF R\&D Systems 236 EG) na concentração de $10 \mathrm{ng} / \mathrm{mL}$.

A contagem do número de células por poço foi realizada no dia zero, primeiro, segundo, terceiro, sétimo, décimo e décimo quarto dias. O teste de vitalidade celular foi realizado utilizando-se o corante transmembrana não vital tripan blue. As culturas foram acompanhadas por visualização ao microscópio óptico e registro fotográfico.

\subsection{Avaliação da influência do tipo da camada de sustentação e da suplementação no meio de cultura no cultivo de queratinócitos.}

\subsubsection{Preparo do lisado de plaqueta do tipo sanguíneo O (PLO)}

Foram descongelas 38 bolsas de concentrado de plaquetas do tipo sanguíneo $\mathrm{O}$, fator $\mathrm{RH}+$, com média de aproximadamente $8,5 \times 10^{8}$ plaquetas $/ \mathrm{mL}$. 
A cada uma delas foram acrescentados $100 \mathrm{UI} / \mathrm{mL}$ de heparina e em seguida as bolsas foram submetidas a 4 ciclos de congelamento e descongelamento. Após a último descongelamento, o conteúdo das bolsas foi reunido e submetido a 4 ciclos de centrifugação à $3615 \mathrm{~g}$ durante 30 minutos cada, conforme descrito em 4.4. $\mathrm{O}$ lisado obtido foi utilizado, tanto para confecção do meio de cultura para os fibroblastos humanos, como para o meio de cultura dos queratinócitos.

\subsubsection{Preparo da camada de sustentação}

Aproximadamente $0,5 \times 10^{6}$ fibroblastos murinos (CCL-92, ATCC) foram descongelados e semeados em garrafas de cultura, na densidade de $3,0 \times 10^{3}$ células $/ \mathrm{cm}^{2}$, em meio de cultura suplementado com $10 \% \mathrm{CS}$. Paralelamente, foram cultivados fibroblastos humanos na mesma densidade a da cultura anterior, no entanto, o meio utilizado para propagação destas células foi suplementado com 10\% LPO. As culturas foram mantidas em incubadora úmida a $37 \stackrel{\circ}{\circ}$ com atmosfera de $5 \%$ de $\mathrm{CO}_{2}$. Quando as células atingiram a subconfluência, foram retiradas da garrafa de cultura com solução de Tripsina 0,05\%/EDTA 0,02\%, contadas e irradiadas nas doses 60 Gy (CCL-92), 70, 100, 200 e 300 Gy (fibroblastos humanos) na taxa de doses de 567 Gy/h.

\subsubsection{Cultura dos Queratinócitos}

Os queratinócitos foram obtidos a partir de biopsia de pele, doadas pelo Banco de Tecidos do Instituto Central do Hospital das Clínicas (ICHC) da FMUSP. As amostras de pele foram submetidas a tratamento de dissociação celular com ação enzimatica (Tripsina 0,05\%/EDTA 0,02\%), em períodos de 30 minutos à temperatura de $37^{\circ} \mathrm{C}$. Os queratinócitos obtidos foram semeados na densidade de $2 \times 10^{4}$ células $/ \mathrm{cm}^{2}$ sobre uma camada de sustentação constituída por fibroblastos murinos (CCL-92) previamente irradiados a 60 Gy. O conjunto queratinócitos/feeder layer foi nutrido por meio de cultura $\mathrm{K}+$ e mantido em incubadora úmida a $37^{\circ} \mathrm{C}$ com atmosfera de $5 \%$ de $\mathrm{CO}_{2}$. Na subconfluência da cultura primária, as células foram retiradas com Tripsina 0,05\%/EDTA 0,02\% e semeadas em uma nova camada de sustentação, obtendo-se assim a cultura secundária. Na subconfluência da cultura secundária, as células foram retiradas, contadas e utilizadas para os experimentos. 


\subsubsection{Teste de eficiência de formação de colônias}

$O$ teste de eficiência de formação de colônias (EFC) consistiu em avaliar a diferença entre o cultivo de queratinócitos em diferentes condições, tais como: tipos de camadas de sustentação (CCL-92 e fibroblasto humano); densidades $\left(0,3\right.$ e $0,4 \times 10^{5}$ células $\left./ \mathrm{cm}^{2}\right)$; doses de irradiação para os fibroblastos humanos (70, 100, 200 e $300 \mathrm{~Gy})$; e diferentes suplementos no meio de cultura para queratinócitos ( $10 \%$ soro fetal bovino ou $5 \%$ lisado de plaqueta do tipo sanguíneo O), conforme APÊNDICE A. Os fibroblastos murinos (CCL-92) irradiado a 60 Gy foram utilizados como controle dos experimentos.

Após a semeadura dos fibroblastos irradiados (CCL-92 e fibroblastos humano) nas diferentes condições, foram adicionados 100 queratinócitos por poço. A cultura queratinócito/camada de sustentação foi mantida em meio de cultura contendo SFB ou LPO, a troca do meio foi efetuada a cada 48 horas por catorze dias. Decorrido esse período, as culturas foram coradas com Rodamina B e as colônias de queratinócitos foram analisadas morfologicamente e contadas, levando em consideração o número de colônias em desenvolvimento e a formação de colônias abortivas.

\subsection{Análise estatística}

Os resultados obtidos foram expressos como média e desvio padrão das médias. As significâncias estatísticas das diferenças foram determinadas pela análise de variância (ANOVA), teste de Bonferroni e o teste de regressão múltipla. Valores de $p<0,05$ foram considerados significativos. Todos os cálculos foram realizados utilizando-se os software estatísticos GraphPad Prism for Windows, versão 5.0 e IBM SPSS Statistics, versão 18.0 . 


\section{RESULTADOS}

\subsection{Teste de adição de heparina nos concentrados de plaquetas}

Durante o preparo dos lisados de plaquetas, foram avaliadas as possíveis diferenças entre as amostras heparinizadas (A1, A2, A3, B1, B2 e B3) e não heparinizadas (C1, C2, C3). Para isso, verificou-se o aparecimento de coágulos, agregados na superfície, suspensões e botão celular (vide FIG. 10 de Materiais e Métodos).

Não foi observada presença coágulos em nenhuma das amostras, tanto durante $\mathrm{o}$ processo de lise das plaquetas (congelamento $\mathrm{e}$ descongelamento), quanto após cada ciclo de centrifugação.

Em relação aos agregados na superfície, só puderam ser observados após cada ciclo de centrifugação. Estes se mostraram heterogêneos para todas as amostras, independente da heparinização ou não.

Quanto às suspensões notadas durante as centrifugações, também se mostraram heterogêneas tanto para as amostras heparinizadas quanto para não heparinizadas.

Em relação ao botão celular obtido após as centrifugações, observouse que o volume destes diminuía a cada centrifugação, entretanto, foi verificado aparecimento do mesmo até a última centrifugação, para todas as amostras. Sendo que para as amostras não heparinizadas o volume de precipitados pareceu sempre superior após a segunda centrifugação.

Como não foram verificadas diferenças, quanto às características acima descritas, o preparo do lisado de plaqueta foi padronizado com 4 ciclos, de 6 horas de congelamento e 15 minutos de descongelamento, seguidos por 4 ciclos de centrifugação de 30 minutos cada. Quanto a adição de heparina nesta fase, somente estas características não foram suficientes para sua padronização, sendo necessária a complementação com os resultados dos experimentos a seguir.

\subsubsection{Proliferação dos fibroblastos com soro fetal bovino versus lisados de plaquetas}

Com intuito de verificar o desenvolvimento celular dos fibroblastos humanos, em meio contendo lisados de plaquetas (LPA, LPB e LPC) comparando-os com o soro fetal bovino (SFB), foi realizado o ensaio de 
proliferação celular. Onde, LPA corresponde ao meio de cultura preparado com o lisado $\mathrm{A}$ (já heparinizado antes da lise), com adição de mais $2 \mathrm{UI}$ de heparina / $\mathrm{mL}$ de meio de cultura; LPB corresponde ao meio de cultura preparado com o lisado $\mathrm{B}$, somente heparinizado antes da lise; e o LPC corresponde ao meio de cultura preparado com o lisado $\mathrm{C}$ (não heparinizado antes da lise), com adição de mais $2 \mathrm{UI}$ de heparina / $\mathrm{mL}$ de meio de cultura (vide item 4.4.1).

$\mathrm{Na}$ FIG.11 pode-se observar a curva de proliferação celular dos fibroblastos humanos, cultivados com $10 \%$ de SFB, LPA, LPB e LPC, ao longo de 120 horas.

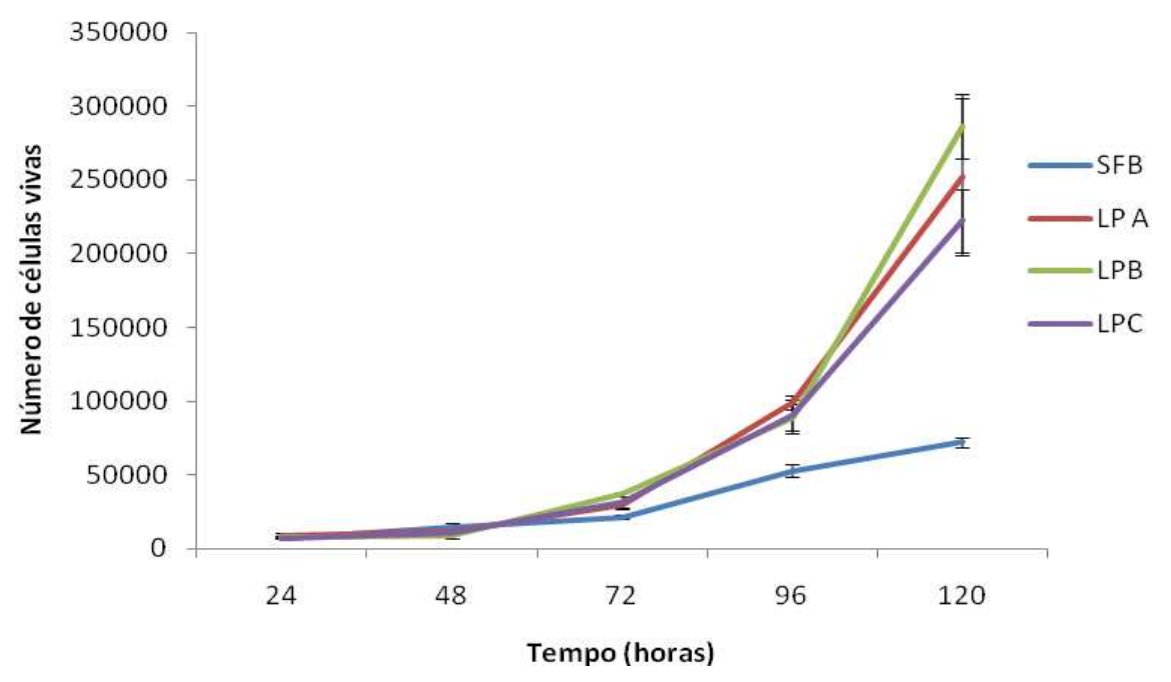

FIGURA 11 - Gráfico da proliferação celular dos fibroblastos humanos cultivados com meio suplementado com $10 \%$ de SFB, $10 \%$ de LPA, $10 \%$ de LPB, $10 \%$ de LPC.

No tempo de 24 e 48 horas não foram observadas diferenças significativas entre o número de células cultivadas, tanto no meio suplementado com $10 \%$ de SFB, como os LPA, LPB e LPC. Porém, o mesmo não ocorreu após 72, 96 e 120 horas, onde observou-se uma melhor proliferação celular em meios suplementados com lisados de plaquetas. Não foram encontradas diferenças significativas entre os lisados A, B e C nos intervalos analisados.

Mudanças nos aspectos morfológicos entre os fibroblastos cultivados nos meios com LP e o SFB foram observadas no microscópio óptico (FIG. 12), onde se verificou que as células cultivadas com os lisados, aparecem menores e com citoplasma mais definido, quando comparadas ao controle. 

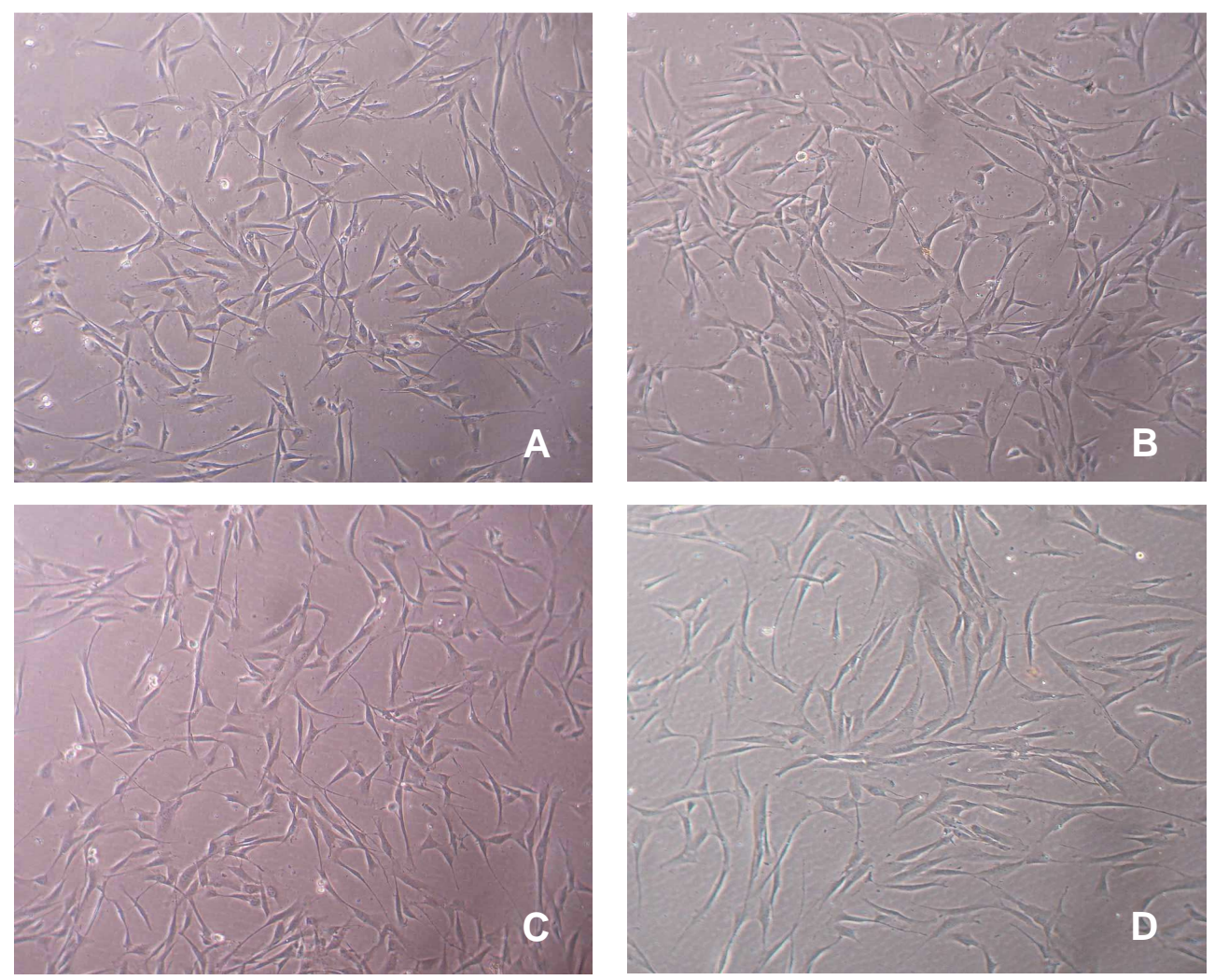

FIGURA 12 - Fotografias das observações ao microscópio óptico dos fibroblastos humanos cultivados com $10 \%$ de LPA (A), $10 \%$ de LPB (B), $10 \%$ de LPC (C) $10 \%$ de SFB (D), após 72 horas. Aumento de 100 vezes com filtro azul.

\subsubsection{Avaliação da adesão celular}

No ensaio de adesão celular foi observado o efeito dos lisados de plaquetas (LPA, LPB e LPC), preparados nas diversas concentrações $(2,5 \%, 5 \%$ e 10\%), na adesão dos fibroblastos humanos, após 24 horas, conforme representado na FIG. 13. Como controle, utilizou o meio próprio para fibroblastos, suplementado com $10 \%$ de SFB. Neste experimento, também foi avaliada a possibilidade de utilização do soro de bezerro (CS), utilizado no meio de cultura dos fibroblastos murinos CCL-92. 


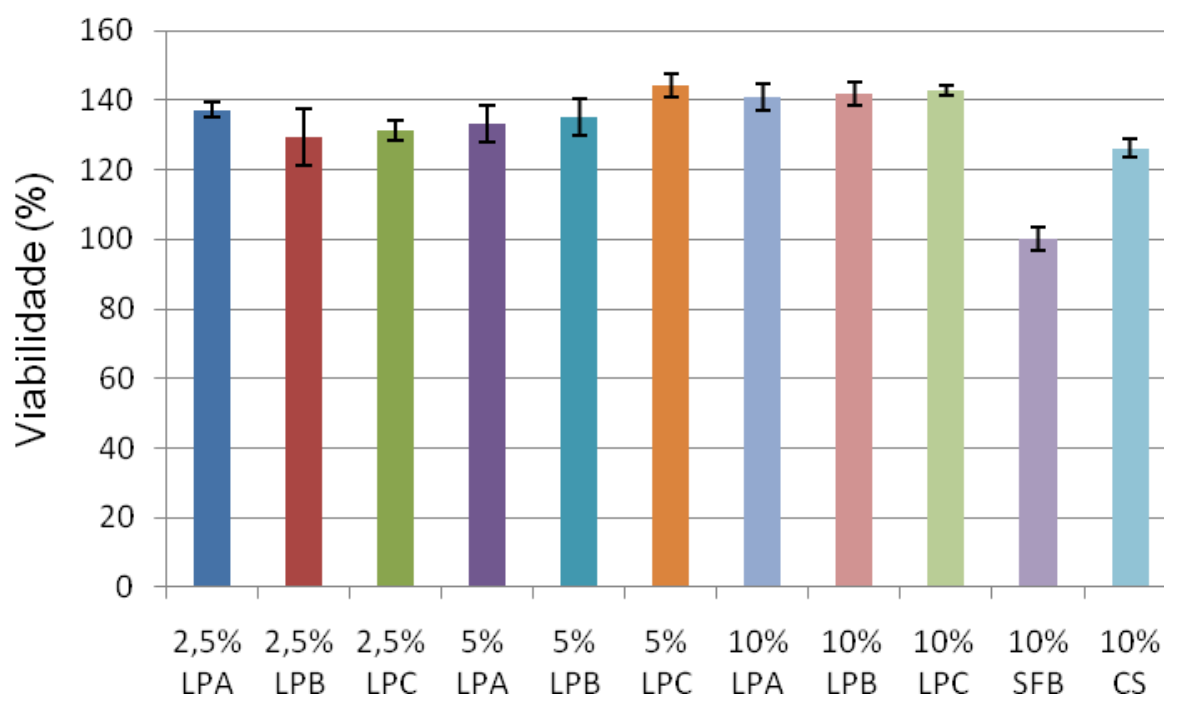

FIGURA 13 - Efeito dos LPs nas diversas concentrações, na adesão dos fibroblastos humanos, após 24 horas de contato.

Conforme ilustrado na FIG. 13 nota-se, em todos os meios de cultura testados LPA, LPB, LPC e CS, que a viabilidade celular foi significativamente maior do que no controle (SFB), ou seja, tanto os lisados de plaquetas, quanto o CS, proporcionaram uma melhor adesão celular do que o SFB, no tempo de 24 horas, independente da concentração. Sendo que esta diferença, também foi estatisticamente significativa, para os LPs a 10\% e LPC a 5\%, em relação ao CS.

Na FIG. 14 são mostradas as imagens dos fibroblastos humanos aderidos à superfície de cultivo, após estes serem semeados com os diferentes meios contendo, SFB, SC e os LPs, nas diferentes concentrações. Onde observase que os meios suplementados com LP a $10 \%$ proporcionou melhor adesão dos fibroblastos, em relação as demais concentrações. Verificou-se, também, que ocorreram modificações na morfologia dos fibroblastos, com o aumento da concentração de LP, sendo que na menor concentração $(2,5 \%)$, estes se apresentaram semelhantes aos cultivados com SFB. 

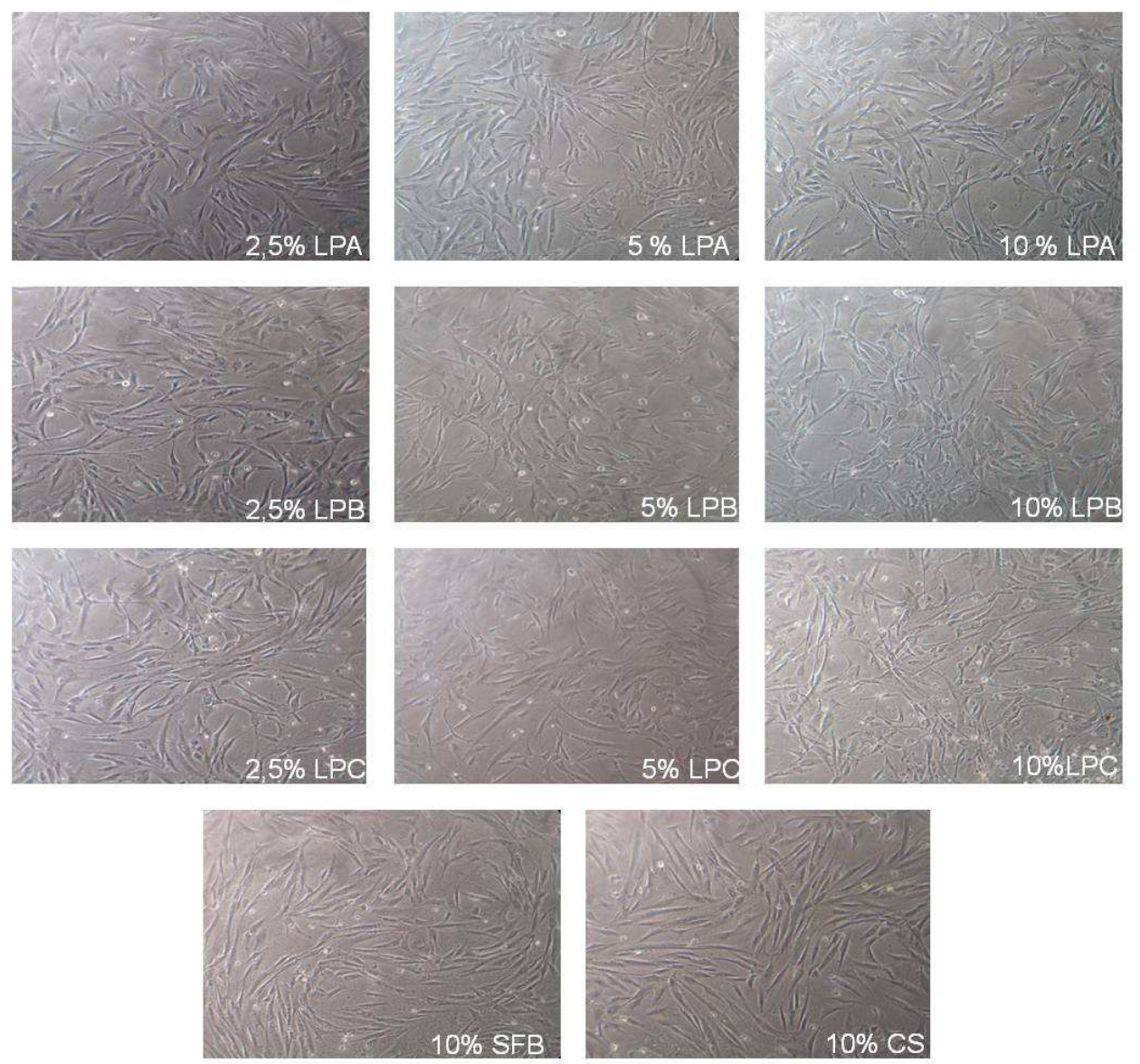

FIGURA 14 - Fotografias das observações ao microscópio óptico do efeito do LP nas diversas concentrações na adesão dos fibroblastos, após 24 horas de contato. Aumento de 100 vezes, com filtro azul.

\subsubsection{Comparação da viabilidade celular dos fibroblastos humanos nos diferentes meios em relação ao meio com SFB.}

Neste ensaio verificou-se o efeito do meio de cultura, com as diferentes formas de obtenção e concentração dos lisados de plaquetas, na viabilidade dos fibroblastos humanos cultivados nos tempos: 24, 48, 72 e 96 horas, comparando os mesmos com a viabilidade dos fibroblastos humanos cultivados em SFB, conforme ilustrado nas FIG. 15 a 18. 


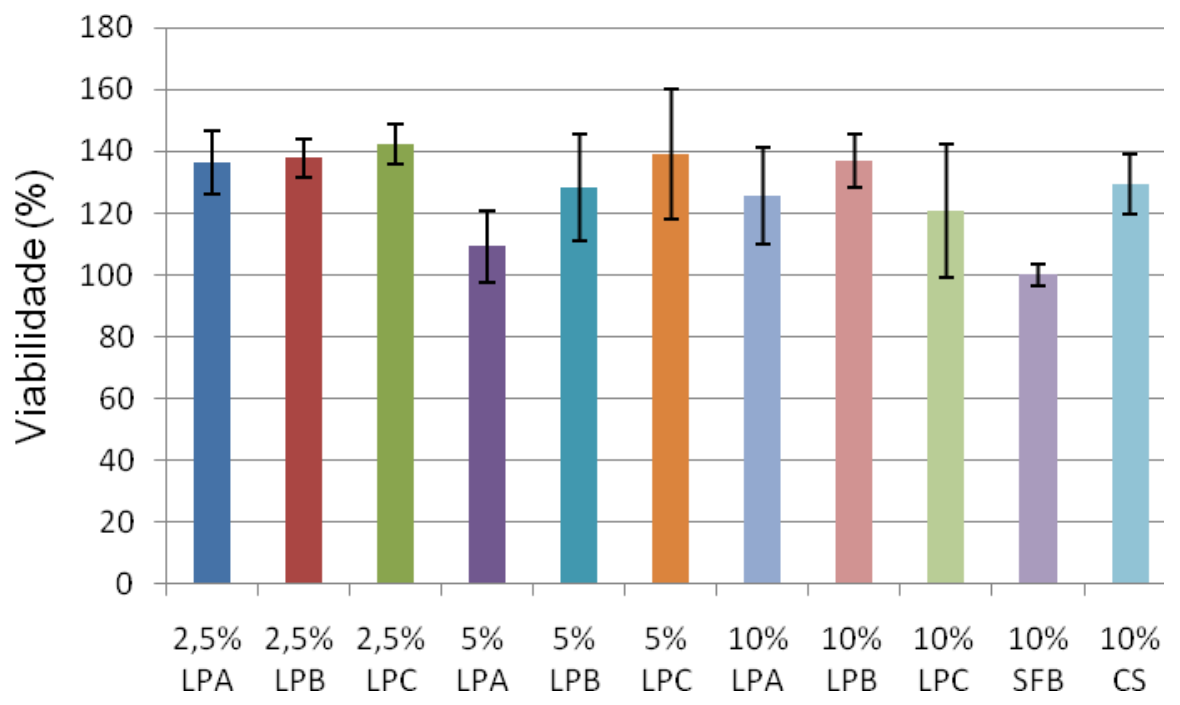

FIGURA 15 - Gráfico da viabilidade dos fibroblastos humanos cultivados nas diferentes concentrações de lisados de plaquetas (LPA, LPB e LPC) e soro de bezerro (CS), no tempo de 24 horas. Considerando o cultivo em SFB como 100\% de viabilidade.

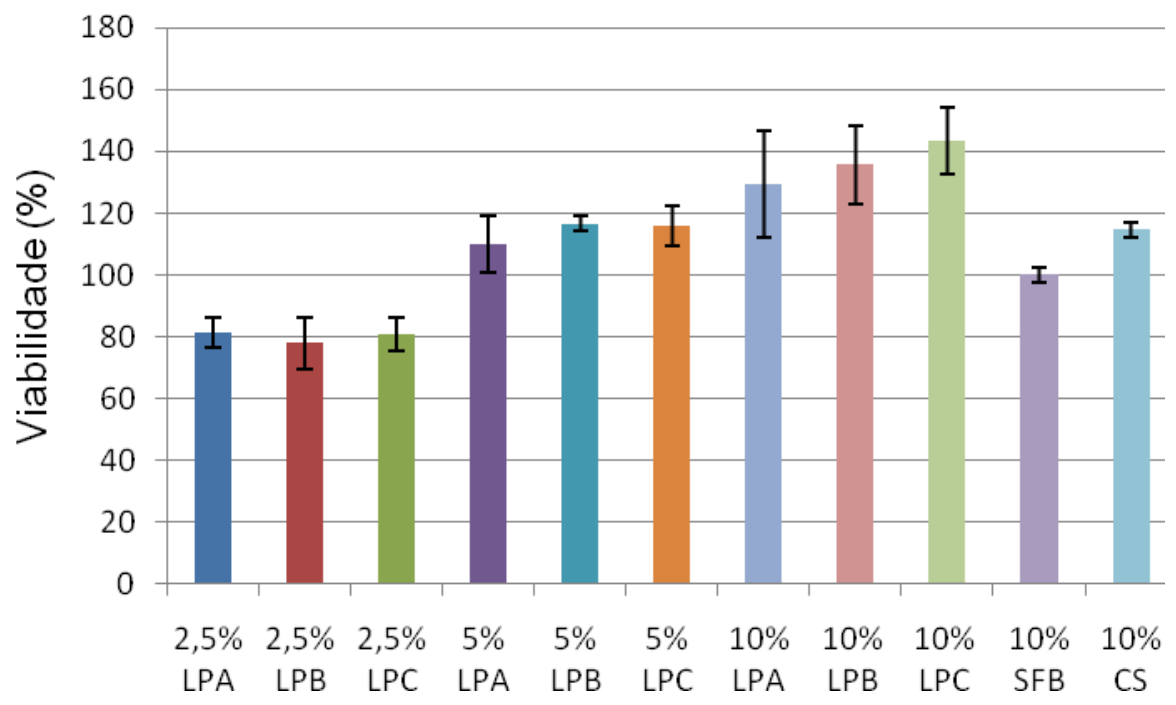

FIGURA 16 - Gráfico da viabilidade dos fibroblastos humanos cultivados nas diferentes concentrações de lisados de plaquetas (LPA, LPB e LPC) e soro de bezerro (CS), no tempo de 48 horas. Considerando o cultivo em SFB como $100 \%$ de viabilidade. 


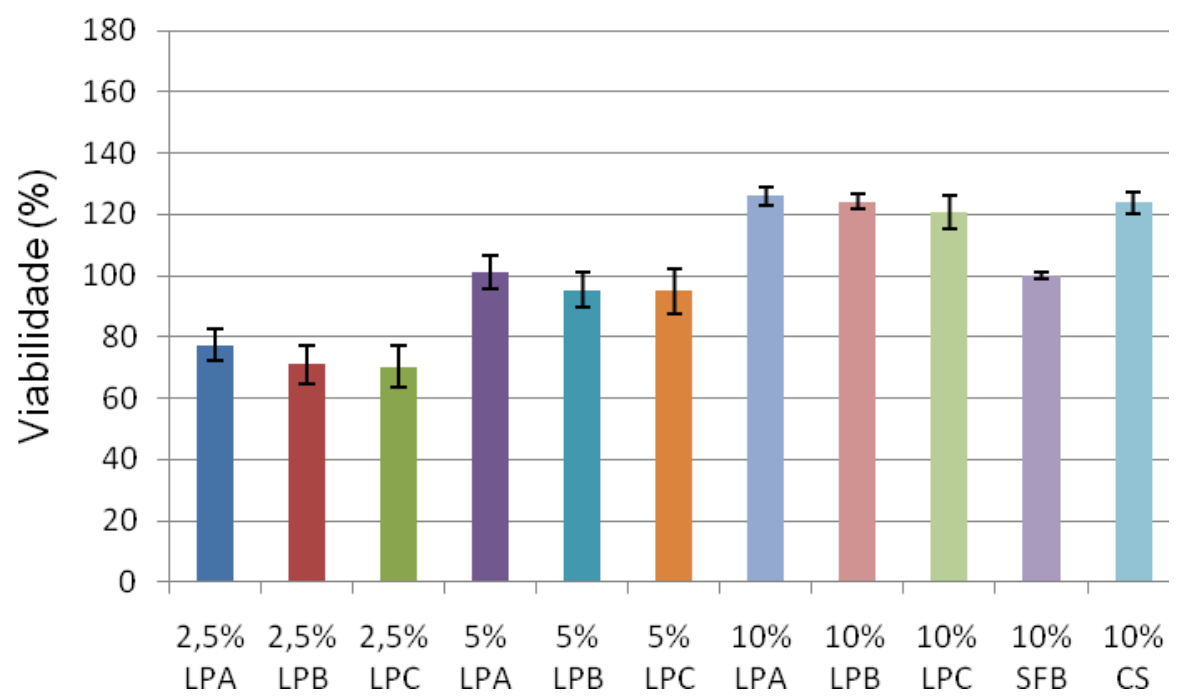

FIGURA 17 - Gráfico da viabilidade dos fibroblastos humanos cultivados nas diferentes concentrações de lisados de plaquetas (LPA, LPB e LPC) e soro de bezerro (CS), no tempo de 72 horas. Considerando o cultivo em SFB como 100\% de viabilidade.

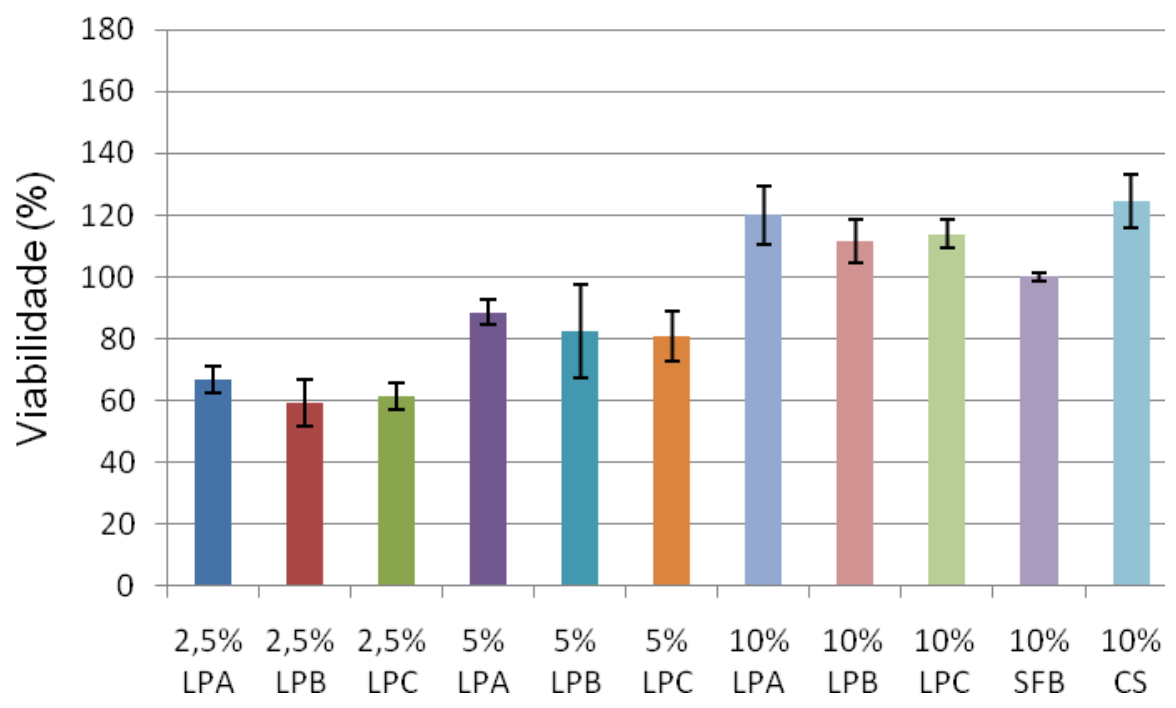

FIGURA 18 - Gráfico da viabilidade dos fibroblastos humanos cultivados nas diferentes concentrações de lisados de plaquetas (LPA, LPB e LPC) e soro de bezerro (CS), no tempo de 96 horas. Considerando o cultivo em SFB como 100\% de viabilidade.

Verificou-se que após 24 horas, a maioria das culturas mantidas em meios com lisado apresentaram uma viabilidade estatisticamente superior ao controle, com exceção de LPA (5\%) e LPC (10\%), sendo que neste último podese observar um aumento do desvio padrão. Após 48 horas, observou-se, uma queda na viabilidade celular na presença de $2,5 \%$ de todos os lisados de 
plaquetas. As células cultivadas em concentrações de 5\% e 10\% apresentaram viabilidades estatisticamente superiores ao controle, com exceção do LPA (5\%), onde não foi observada diferença significativa em relação ao controle. Nos tempos de 72 e 96 horas, observou-se que somente as culturas contendo $10 \%$ dos lisados tiveram viabilidade estaticamente superior ao controle.

Em relação ao cultivo dos fibroblastos humanos com meio contendo CS, pode-se observar aumento da viabilidade celular, em todos tempos, quando comparada à viabilidade destas células cultivadas em SFB.

O cultivo dos fibroblastos, com os meios de cultura suplementados com LP, variando o tipo de obtenção e a concentração, foi acompanhado por visualização ao microscópio óptico e registro fotográfico, para verificação de possíveis mudanças na morfologia celular, nos tempos determinados (FIG. 19). Observa-se que os fibroblastos cultivados, tanto em meios contendo SFB, quanto CS apresentam-se morfologicamente maiores e fusiformes em relação aos cultivados com lisado. As diferenças morfológicas, ao longo do tempo, não foram detectadas devido à alta concentração celular, verificando-se maior acúmulo celular nas culturas suplementadas com lisado de plaquetas (principalmente nas concentrações de 5 e 10\%), corroborando os resultados apresentados nas FIG. 15 a 18. Não foram observadas diferenças morfológicas entre os fibroblastos cultivados em meios com os diferentes lisados, em nenhuma das concentrações estudadas $(2,5 \%, 5 \%$ e $10 \%)$.

De acordo com os resultados obtidos, pode-se verificar que a concentração e o momento da adição da heparina, tanto durante a lise (LPA e LPB), quanto no preparo do meio de cultura (LPA e LPC), não interferiram na adesão, na viabilidade e na morfologia dos fibroblastos. Portanto, foi determinada a utilização do lisado B (LPB) para a realização dos experimentos subseqüentes, devido à sua praticidade. A concentração do lisado de plaquetas determinada para os ensaios posteriores foi a de $10 \%$, por este proporcionar uma maior proliferação celular quando comparada com o controle (SFB). 


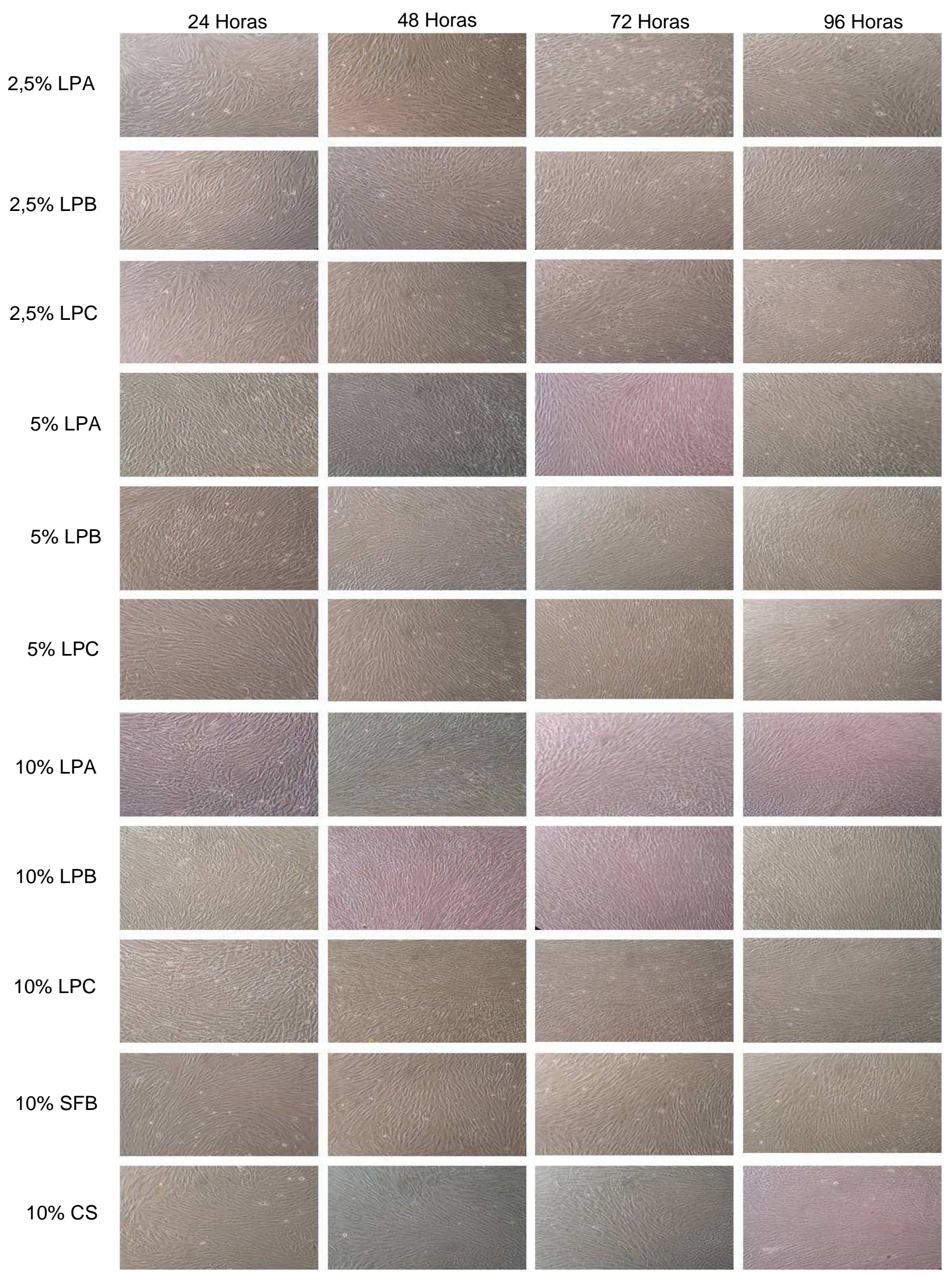

FIGURA 19 - Fotografias das observações ao microscópio óptico do efeito dos diferentes suplementos e suas concentrações, no desenvolvimento dos fibroblastos humanos, nos tempos de 24, 48, 72 e 96 horas. Aumento de 100 vezes, com filtro azul. 
5.2 Avaliação do efeito dos tipos sanguíneos das origens das plaquetas lisadas

\subsubsection{Avaliação da Adesão Celular}

Uma vez estabelecida a concentração de $10 \%$ como ideal para substituição o SFB por lisado de plaqueta no meio de cultura para fibroblastos humanos, passamos a analisar se lisados de plaquetas obtidos dos diferentes tipos sanguíneos $A, B, A B, O$ e Pool (união dos tipos sanguineos), (LA, LB, LAB, LO e LPool, respectivamente) poderiam influenciar na adesão dessas células (FIG. 20).

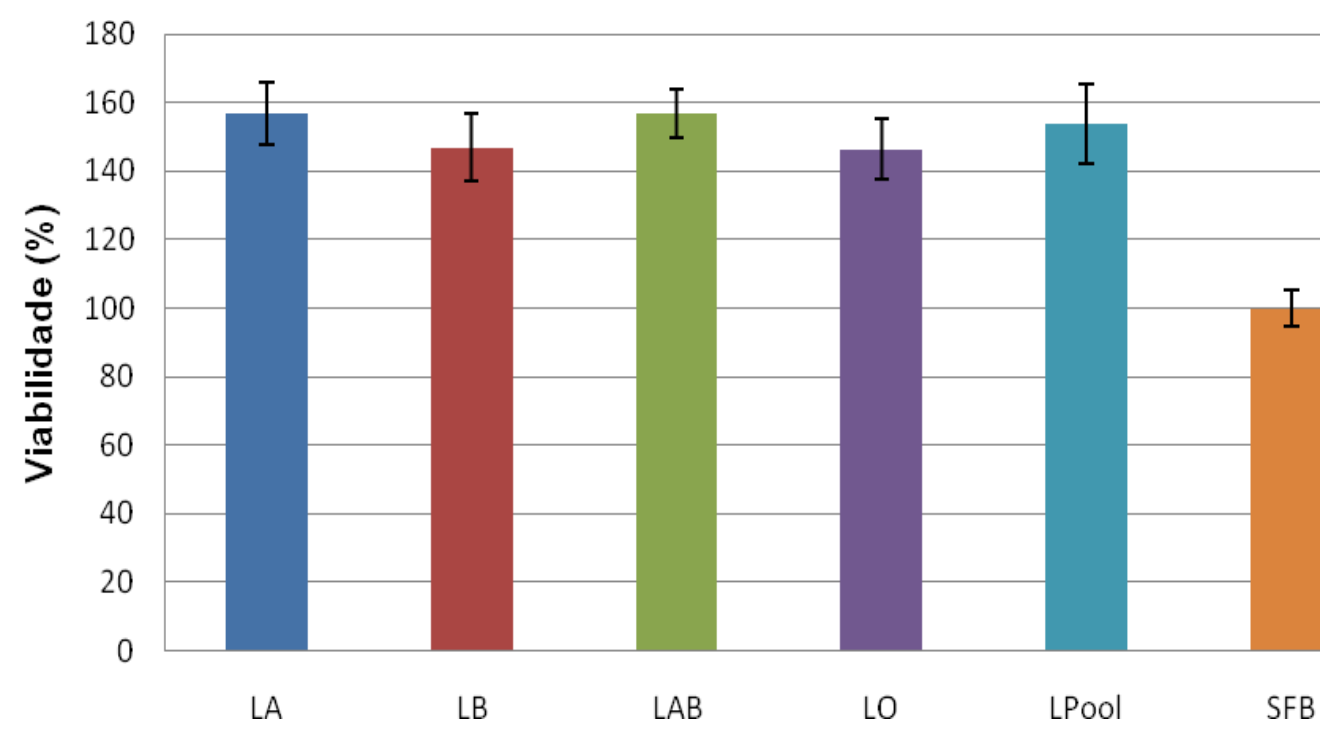

FIGURA 20 - Adesão dos fibroblastos, após 24 horas de contato, com meios suplementados com lisado de plaquetas provenientes dos quatro tipos sangüíneos e do pool. Como controle, foram utilizados fibroblastos cultivados em meio contendo SFB, sendo este considerado como $100 \%$ de viabilidade.

Nota-se que o lisado de plaquetas proporcionou uma melhor adesão, independente da tipagem sanguínea, apresentando um aumento na viabilidade celular em torno de $50 \%$ em relação ao controle (SFB). Não foram observadas diferenças significativas ao analisar os lisados entre si. 
Na FIG. 21 podemos observar o aspecto morfológico dos fibroblastos semeados, e mantidos em contato por 24 horas, com meios suplementados com lisados de plaquetas provenientes de diferentes tipos sanguíneos e o pool destes lisados. Verifica-se que não ocorreram diferenças morfológicas entre os fibroblastos cultivados em lisados provenientes de diferentes tipagens sanguíneas, porém ao compará-los com o controle, nota-se que neste as células apresentam-se maiores e mais fusiformes.
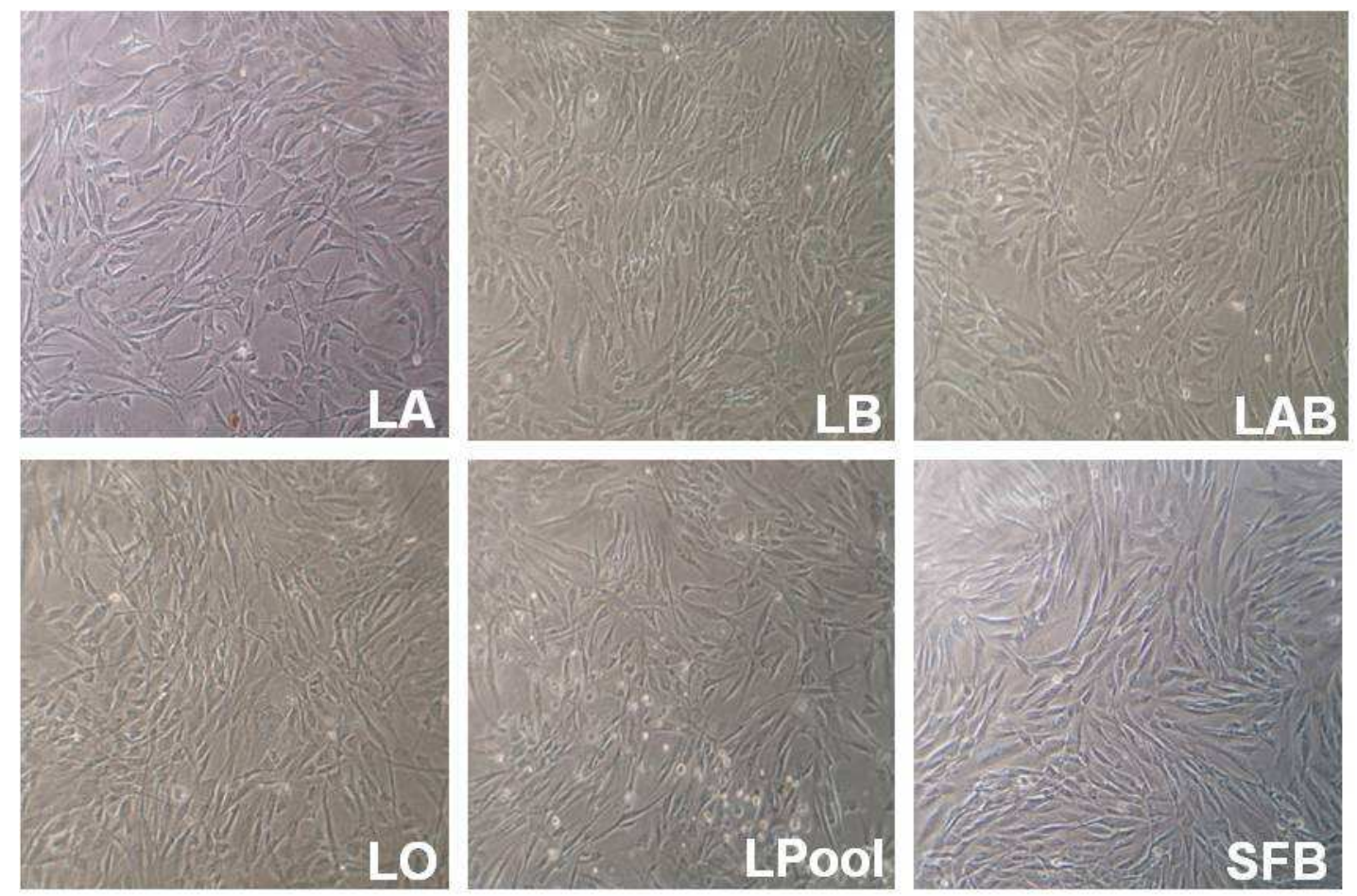

FIGURA 21 - Fotografias das observações ao microscópio óptico da influência do tipo sanguíneo na adesão dos fibroblastos após 24 horas de contato. Aumento de 100 vezes, com filtro azul.

\subsubsection{Comparação da viabilidade celular dos fibroblastos humanos nos diferentes meios em relação ao meio com SFB}

Foi verificada a influência na viabilidade celular, dos lisados de plaquetas oriundos dos quarto tipos sanguíneos e do pool no desenvolvimento dos fibroblastos em relação ao controle (SFB), nos tempos: 24, 48, 72 e 96 horas (FIG. 22 a 25). 


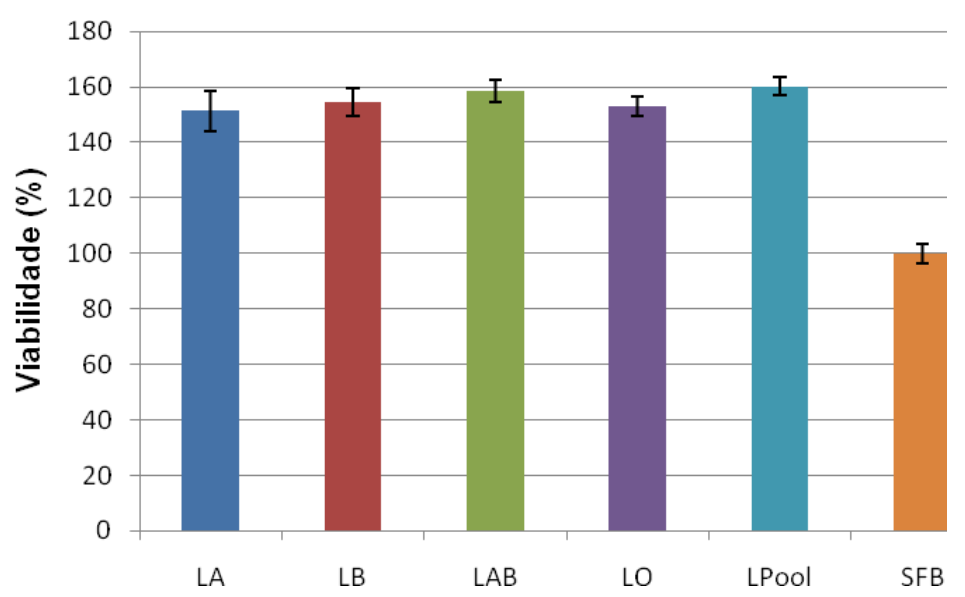

FIGURA 22 - Gráfico da viabilidade celular dos fibroblastos humanos cultivados em meios de cultura contendo lisados de plaquetas de diferentes tipos sanguíneos, no tempo de 24 horas.

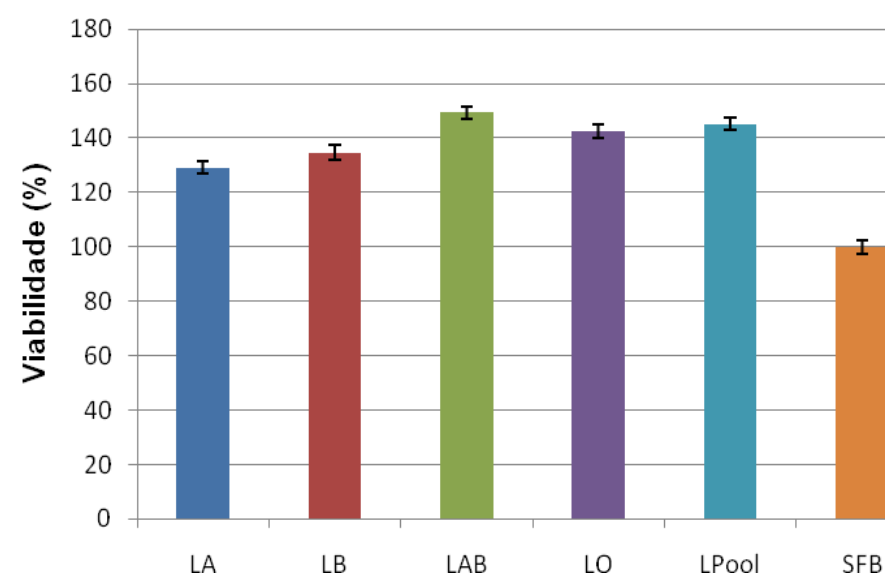

FIGURA 23 - Gráfico da viabilidade celular dos fibroblastos humanos cultivados em meios de cultura contendo lisados de plaquetas de diferentes tipos sanguíneos, no tempo de 48 horas.

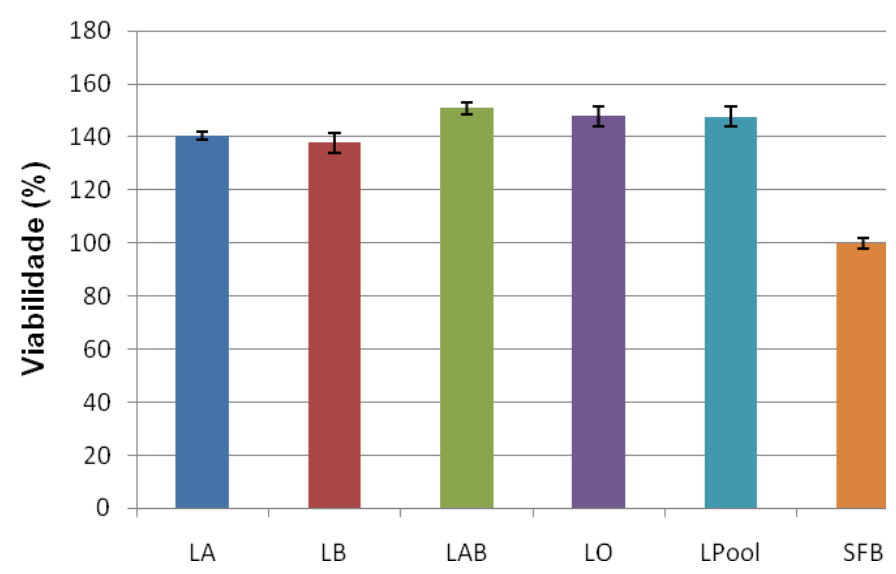

FIGURA 24 - Gráfico da viabilidade celular dos fibroblastos humanos cultivados em meios de cultura contendo lisados de plaquetas de diferentes tipos sanguíneos, no tempo de 72 horas. 


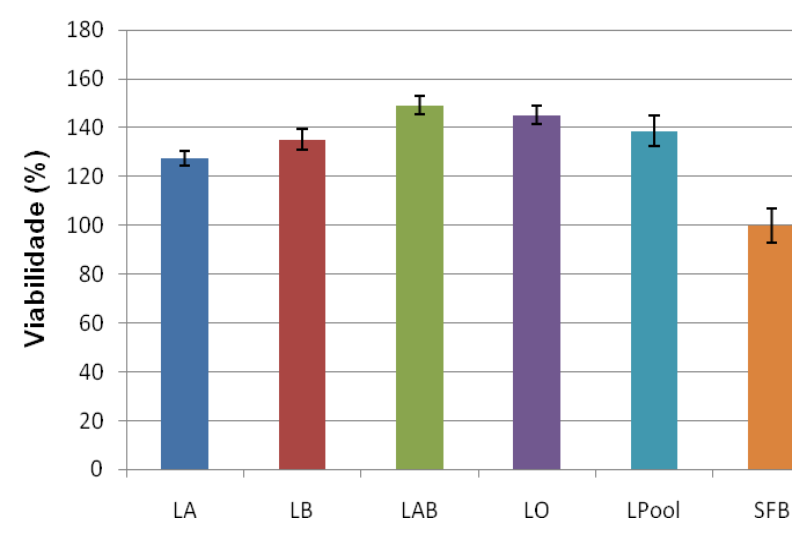

FIGURA 25 - Gráfico da viabilidade celular dos fibroblastos humanos cultivados em meios de cultura contendo lisados de plaquetas de diferentes tipos sanguíneos, no tempo de 96 horas.

Ao avaliar o desenvolvimento celular dos fibroblastos humanos cultivados na presença de lisados de plaquetas, provenientes de diferentes tipos sanguíneos, verificou-se que todos os lisados tiveram uma evolução superior ao controle, nos tempos analisados. Porém, ao analisar os lisados entre si foi observada a influência do tipo sangüíneo no tempo de 48, 72 e 96 horas; onde se verificou no tempo de 48 horas, uma melhora na viabilidade das células suplementadas com lisados do tipo $A B, O$ e Pool em relação ao demais lisados $(A$ e $B$ ). No tempo de 72 horas, foi verificado que somente os lisados $A$ versus $B, A B$ versus Pool, $O$ versus Pool, não apresentaram diferenças significativas entre si, sendo que os lisados $A B$ e Pool proporcionaram uma melhor viabilidade em relação aos demais. No tempo de 96 horas, notou-se que as culturas mantidas com lisados do tipo $A B, O$ e Pool resultaram em uma maior viabilidade celular em relação aos tipos $A$ e $B$, porém não foram verificadas diferenças significativas entre os mesmos.

A FIG. 26 ilustra a morfologia e o crescimento dos fibroblastos cultivados nos meios de cultura suplementados com os lisados de plaquetas provenientes dos diferentes tipos sanguíneos e o pool. Verifica-se que nas culturas com meio suplementados com os lisados, as células se apresentam menores e mais arredondadas, enquanto que nas culturas contendo meio com SFB, estas se apresentaram maiores e mais alongadas durante todo o período de observação. 


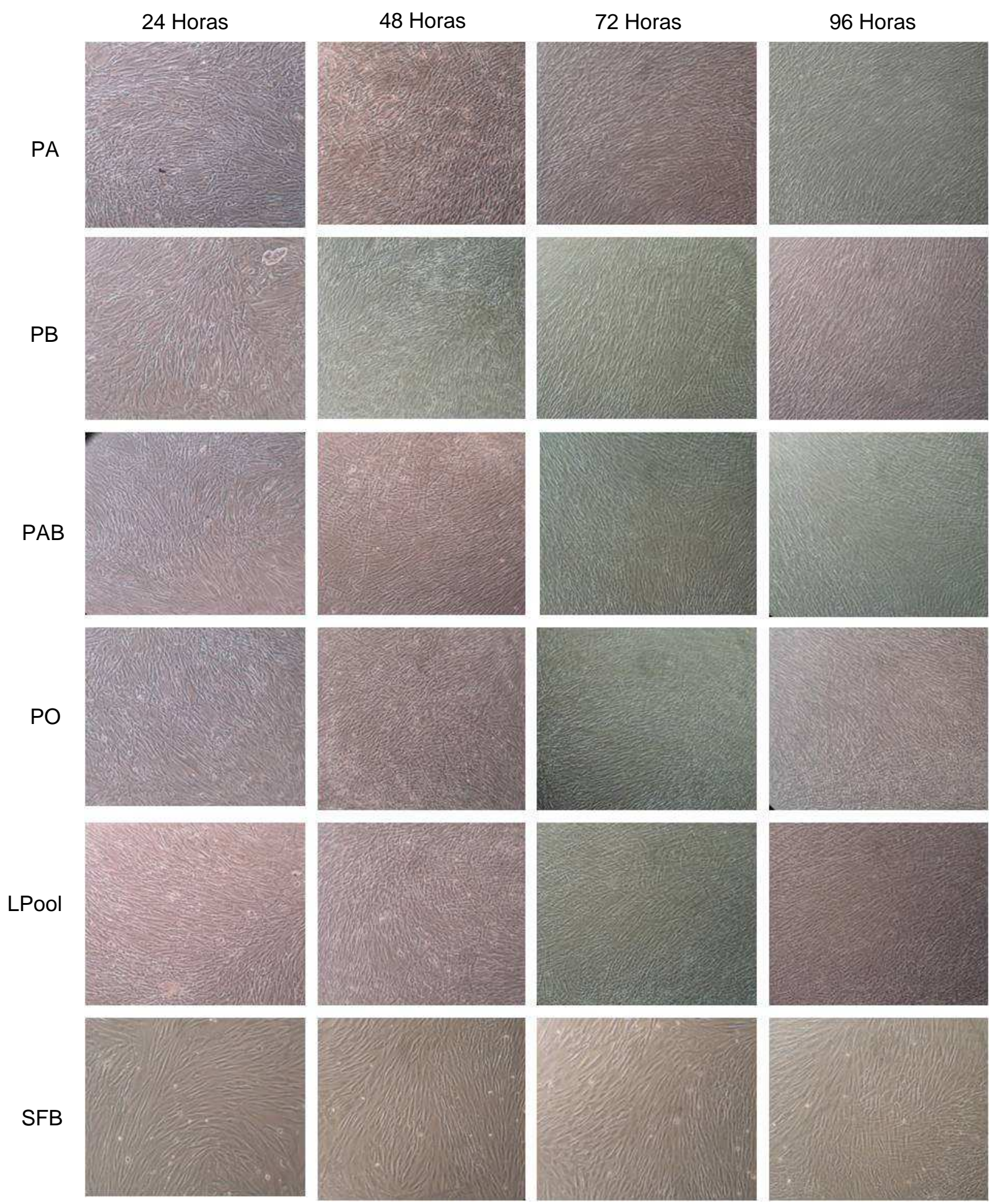

FIGURA 26 - Fotografias das observações ao microscópio óptico da influência do lisados de plaquetas provenientes dos quatro tipos sangüíneos e do pool no desenvolvimento dos fibroblastos humanos nos tempos de 24, 48, 72 e 96 horas. Aumento de 100 vezes, com filtro azul. 


\subsection{Determinação da dose de irradiação necessária para inativação da proliferação dos fibroblastos humanos}

Com o intuito de utilizar os fibroblastos humanos como camada de sustentação para o cultivo de outros tipos celulares, estes foram irradiados com diferentes doses (variando de 60 a $300 \mathrm{~Gy}$ ), com o objetivo de determinar qual a dose ideal para inativar a sua proliferação (FIG. 27), sendo que as curvas obtidas foram comparadas à curva do controle de fibroblastos murinos CCL-92, irradiados a 60 Gy e à curva de proliferação dos fibroblastos humanos não irradiados (FH, 0 Gy).

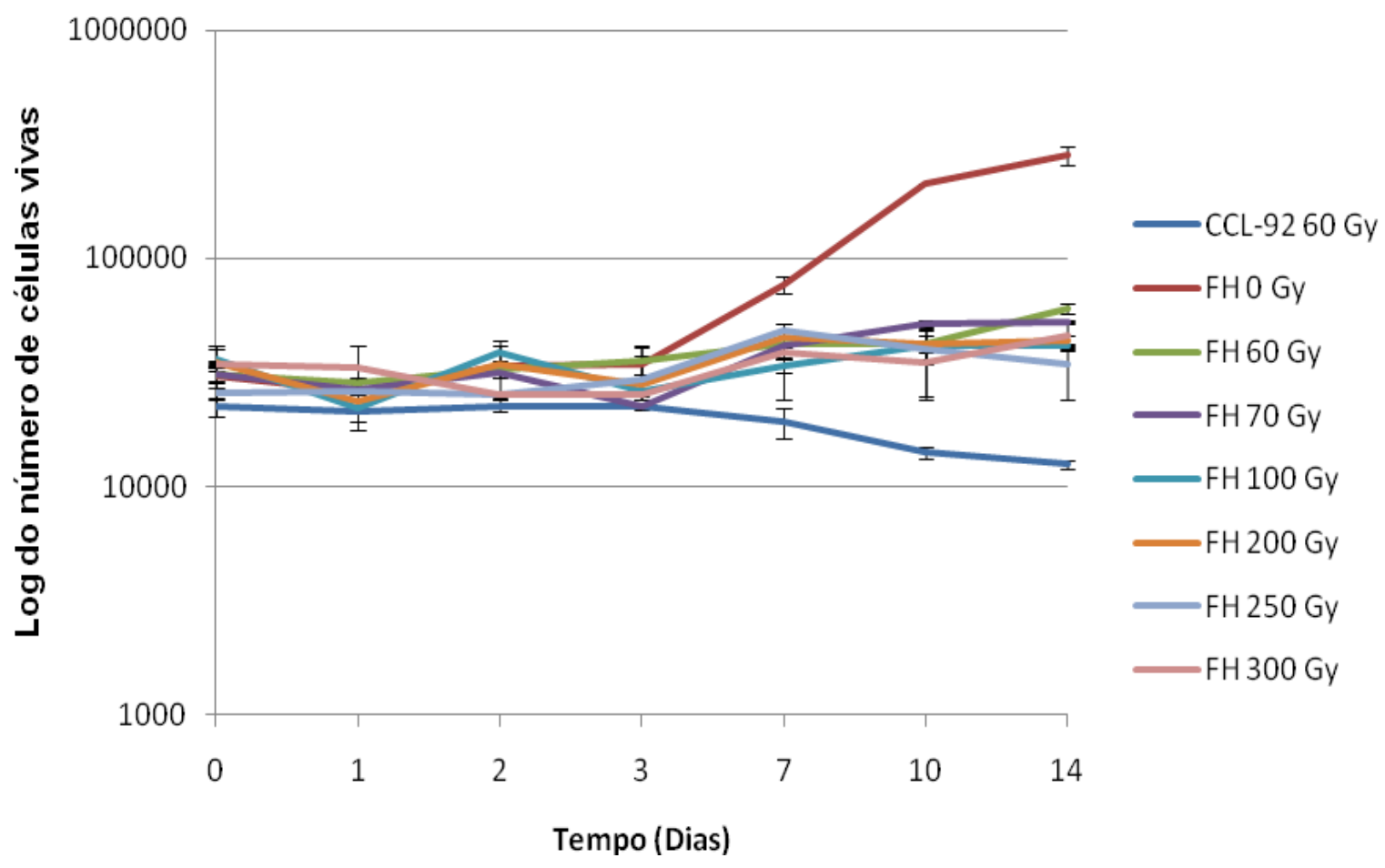

FIGURA 27- Gráfico da curva de sobrevida dos fibroblastos humanos irradiados nas várias doses de radiação, comparadas ao controle (CCL-92, 60 Gy). O controle do ensaio foi determinado pelos fibroblastos humanos não irradiados ( $\mathrm{FH}$, 0 Gy) 
Os resultados revelaram que até o terceiro dia, todas as células irradiadas e não irradiadas apresentavam o mesmo número de células vivas do dia da semeadura (dia zero). Mudanças só foram verificadas no sétimo dia, onde pudemos perceber que fibroblastos humanos não irradiados continuaram a se multiplicar, enquanto os mesmos irradiados apresentaram um discreto aumento no número de células viáveis. O mesmo comportamento não ocorreu para os fibroblastos murinos, onde o número de células viáveis diminuiu ao longo dos 14 dias.

Após o sétimo dia, foi observado que os fibroblastos humanos não irradiados continuaram a se duplicar sucessivamente até 0 término do experimento, enquanto os fibroblastos humanos irradiados pararam a sua duplicação, mantendo o mesmo número de células vivas até o décimo quarto dia. Não se verificou diferença significativa no número de células viáveis, com irradiações no intervalo de doses que variou de 60 a 300 Gy, durante o período em que foi executado o ensaio. Como esperado, o controle com as CCL-92 irradiadas com $60 \mathrm{~Gy}$, apresentou uma curva decrescente após o terceiro dia.

A aparência e integridade como camada de sustentação, após a irradiação dos fibroblastos, foi acompanhada e fotografada ao longo de duas semanas (FIG. 28).

Analisando a FIG. 28 verifica-se um aumento do número de fibroblastos humanos (irradiados e não irradiados) no sétimo dia. No décimo quarto dia, verificam-se mudanças morfológicas em todas as células. Nos fibroblastos murinos (60 Gy) e humanos irradiados a $300 \mathrm{~Gy}$, observa-se o aparecimento de espaço entre as células, sugerindo que até a décimo quarto dia, algumas células começam morrer e se destacar do fundo da placa de cultura. Nas demais condições, pode-se verificar uma densa camada de fibroblastos, intacta. Observa-se, também, que após um tempo de adaptação, os fibroblastos humanos não irradiados, continuam seu ciclo de duplicações. 
Dia zero

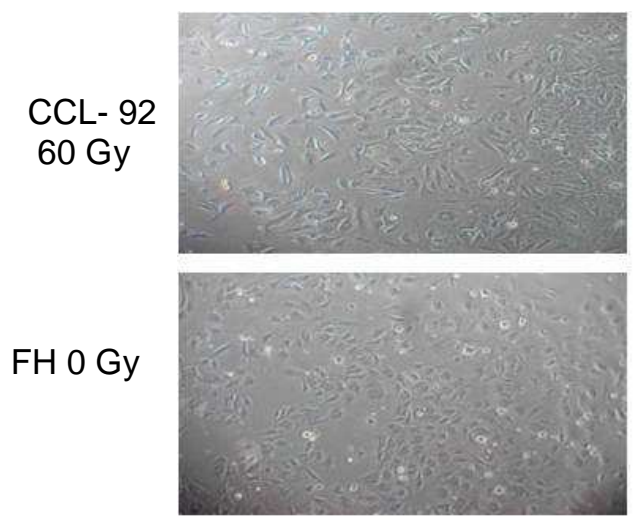

FH 60 Gy

FH 70 Gy

FH 100 Gy

FH 200 Gy
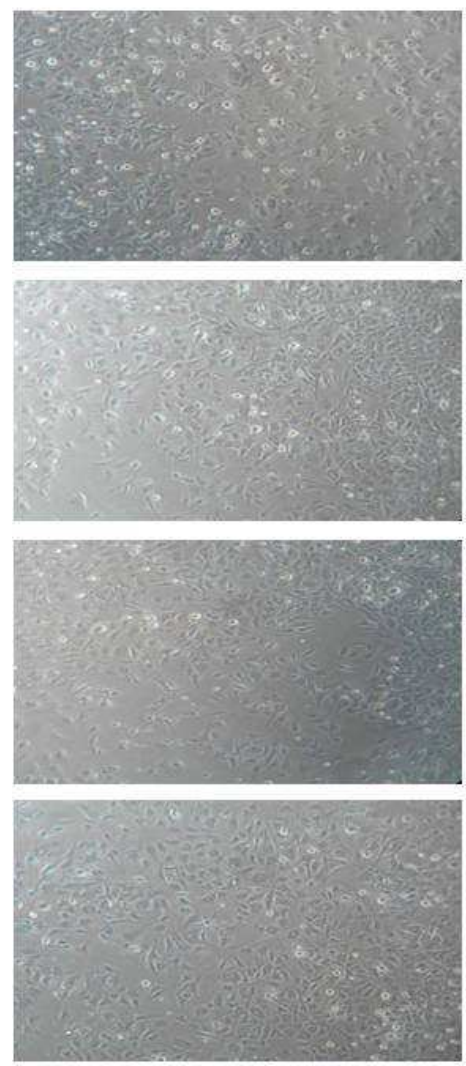

FH 250 Gy

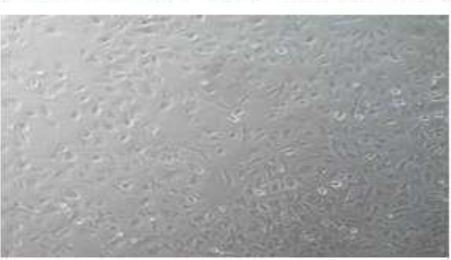

FH 300 Gy

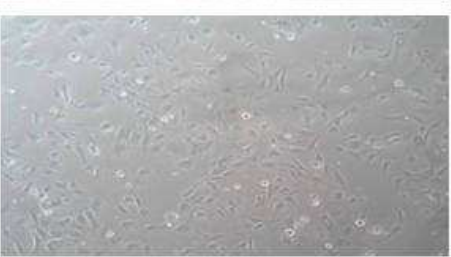

Dia sete
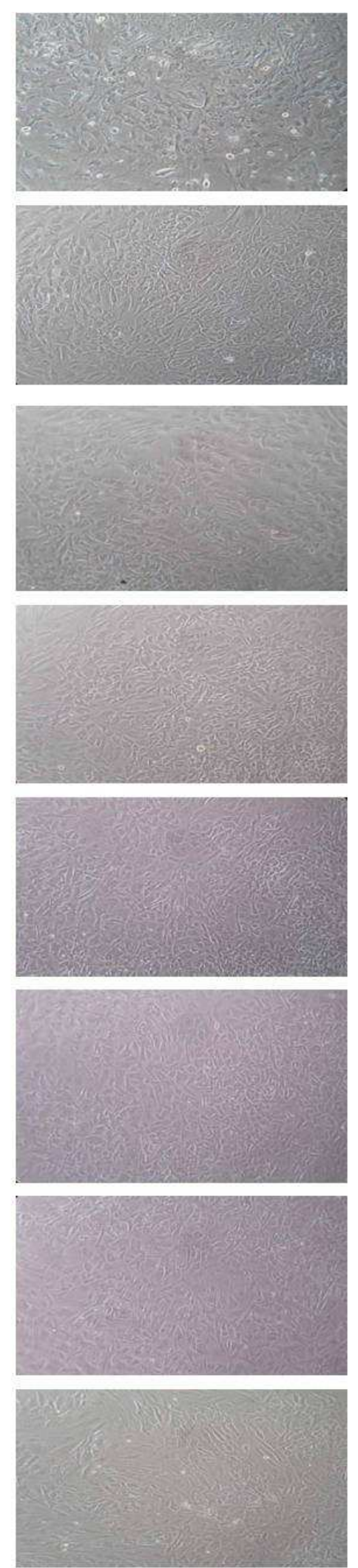

Dia quatorze
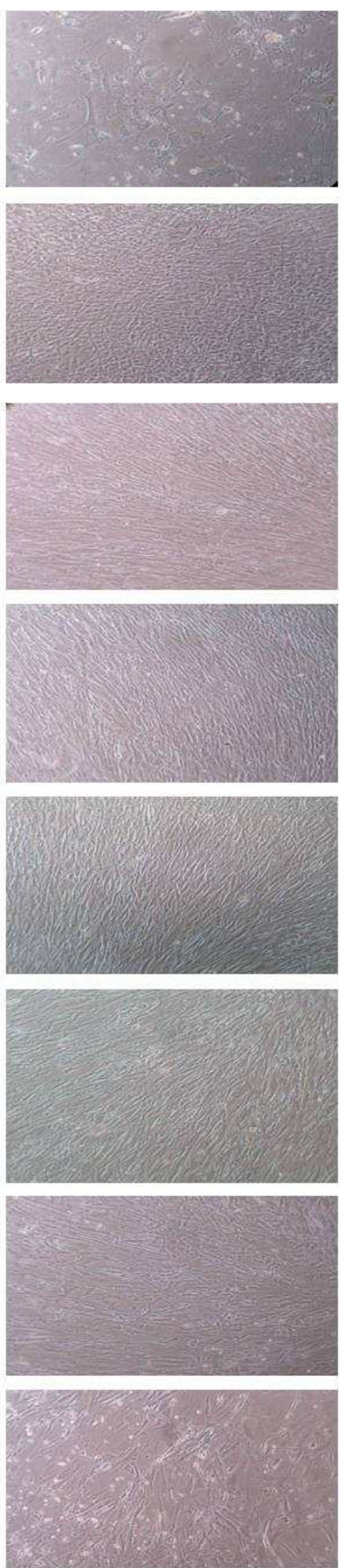

FIGURA 28 - Fotografias das observações ao microscópio óptico dos fibroblastos murinos e humanos irradiados nas diferentes doses, nos dias zero, três e quatorze. Aumento de 100 vezes, com filtro azul. 


\subsection{Avaliação dos efeitos dos tipos de camadas de sustentação, densidade e suplementação do meio de cultura no cultivo de queratinócitos.}

A fim de avaliar a influência dos diferentes tipos de camada de sustentação, densidade e concentração de suplementação do meio de cultura, no desenvolvimento dos queratinócitos foi realizado o teste de eficiência de formação de colônias. Por meio deste teste, pode-se analisar o potencial clonogênico destas células, por meio da visualização e contagem dos diferentes tipos de colônias formadas, como as colônias em desenvolvimento e colônias abortivas.

As colônias em desenvolvimento são colônias grandes que crescem progressivamente por um longo período de tempo. Estas são formadas por células pequenas com alto potencial proliferativo, ou seja, células basais e células no estágio inicial de diferenciação.

Colônias abortivas são aquelas colônias pequenas, com formatos irregulares, contendo células que param sua duplicação depois de um curto espaço de tempo. Estas células perdem a capacidade de proliferar, por terem atingido um determinado estágio de diferenciação e estratificação (Barrandon,1993).

Nas TAB. 3, 4 e 5, estão descritas as porcentagens de colônias em desenvolvimento e a porcentagem de colônias abortivas, obtidas na eficiência de formação de colônias (EFC) de queratinócitos, nas diferentes condições, como: tipos de camadas de sustentação (CCL-92 e fibroblastos humanos); densidade celular da camada de sustentação $\left(0,2 ; 0,26\right.$ e $0,46 \times 10^{5}$ células $\left./ \mathrm{cm}^{2}\right)$; doses de irradiação utilizadas para inativar os fibroblastos (70,100, 150 e 200 Gy; e 60 Gy para o controle); e diferentes suplementos no meio de cultura (10\% soro fetal bovino, $2,5 \%$ ou $5 \%$ de lisado de plaquetas do tipo sanguíneo O), conforme APÊNDICE A. 
TABELA 3 - Porcentagem de colônias em desenvolvimento e abortivas obtidas na eficiência de formação de colônias (EFC) de queratinócitos em camada de sustentação de fibroblastos humanos irradiados, em meio de cultura suplementado com $10 \%$ de SFB

\begin{tabular}{c|c|c|c|c}
\hline \hline Identificação & \multicolumn{2}{|c|}{ Camada de sustentação } & \multicolumn{2}{|c}{ Colônias } \\
(Apêndice A) & $\begin{array}{c}\text { Densidade } \\
\left(10^{5} \text { cél//cm }^{2}\right)\end{array}$ & $\begin{array}{c}\text { Dose } \\
(\text { Gy })\end{array}$ & $\begin{array}{c}\text { Desenvolvimento } \\
(\%)\end{array}$ & $\begin{array}{c}\text { Abortivas } \\
(\%)\end{array}$ \\
\hline EFC 1 & 0,26 & $60^{\#}$ & 5,3 & 2,3 \\
EFC 4 & 0,20 & 70 & 13,6 & 4,0 \\
EFC 7 & 0,20 & 100 & 10,0 & 3,3 \\
EFC 10 & 0,20 & 150 & 12,0 & 4,6 \\
EFC 13 & $0,20^{(*)}$ & 200 & 9,0 & 5,0 \\
EFC 16 & $0,46^{(*)}$ & 200 & 15,6 & 6,0 \\
\hline \hline
\end{tabular}

${ }^{\#}=$ controle com fibroblastos murinos CCL-92

${ }^{(*)}=$ fibroblastos humanos irradiados na dose de 200 Gy e semeados na densidade de $0,20 \times 10^{5} \mathrm{cél} / \mathrm{cm}^{2}$

${ }^{(*)}=$ fibroblastos humanos irradiados na dose de 200 Gy e semeados na densidade de $0,46 \times 10^{5} \mathrm{cél} / \mathrm{cm}^{2}$

TABELA 4 - Porcentagem de colônias em desenvolvimento e abortivas obtidas na eficiência de formação de colônias (EFC) de queratinócitos em camada de sustentação de fibroblastos humanos irradiados, em meio de cultura suplementado com $5 \%$ de LPO

\begin{tabular}{c|c|c|c|c}
\hline \hline Identificação & \multicolumn{2}{|c|}{ Camada de sustentação } & \multicolumn{2}{|c}{ Colônias } \\
(Apêndice A) & $\begin{array}{c}\text { Densidade } \\
\left(10^{5} \text { cél/cm }{ }^{2}\right)\end{array}$ & $\begin{array}{c}\text { Dose } \\
(\text { Gy })\end{array}$ & $\begin{array}{c}\text { Desenvolvimento } \\
(\%)\end{array}$ & $\begin{array}{c}\text { Abortivas } \\
(\%)\end{array}$ \\
\hline EFC 1 & 0,26 & $60^{\#}$ & 5,3 & 2,3 \\
EFC 2 ${ }^{\# \#}$ & 0,26 & $60^{\# \#}$ & 1,6 & 0,6 \\
EFC 5 & 0,20 & 70 & 9,3 & 4,0 \\
EFC 8 & 0,20 & 100 & 6,6 & 4,0 \\
EFC 11 & 0,20 & 150 & 11,0 & 3,0 \\
EFC 14 & $0,20^{(*)}$ & 200 & 5,6 & 9,0 \\
EFC 17 & $0,46^{(*)}$ & 200 & 11,0 & 7,6 \\
\hline \hline
\end{tabular}

${ }_{\#=\text { controle com fibroblastos murinos CCL-92, com meio supl. Com } 10 \% \text { de SFB }}$

\#\# = controle com fibroblastos murinos CCL-92, com meio supl. Com 5\% de LPO

${ }^{(*)}=$ fibroblastos humanos irradiados na dose de 200 Gy e semeados na densidade de $0,20 \times 10^{5} \mathrm{cél} / \mathrm{cm}^{2}$

${ }^{\left.{ }^{*}\right)}=$ fibroblastos humanos irradiados na dose de 200 Gy e semeados na densidade de $0,46 \times 10^{5} \mathrm{cél} / \mathrm{cm}^{2}$ 
TABELA 5 - Porcentagem de colônias em desenvolvimento e abortivas obtidas na eficiência de formação de colônias (EFC) de queratinócitos em camada de sustentação de fibroblastos humanos irradiados, em meio de cultura suplementado com $2,5 \%$ de LPO

\begin{tabular}{c|c|c|c|c}
\hline \hline Identificação & \multicolumn{2}{|c|}{ Camada de sustentação } & \multicolumn{2}{|c}{ Colônias } \\
(Apêndice A) & $\begin{array}{c}\text { Densidade } \\
\left(10^{5} \text { cél/cm }\right)^{2}\end{array}$ & $\begin{array}{c}\text { em } \\
\text { (Gy) }\end{array}$ & $\begin{array}{c}\text { Desenvolvimento } \\
(\%)\end{array}$ & $\begin{array}{c}\text { Abortivas } \\
(\%)\end{array}$ \\
\hline EFC 1\# & 0,26 & $60^{\#}$ & 5,3 & 2,3 \\
EFC 3\#\#\# & 0,26 & $60^{\# \# \#}$ & 2,6 & 4,3 \\
EFC 6 & 0,20 & 70 & 10,3 & 4,6 \\
EFC 9 & 0,20 & 100 & 12,6 & 5,6 \\
EFC 12 & 0,20 & 150 & 12,6 & 2,0 \\
EFC 15 & $0,20^{(*)}$ & 200 & 8,6 & 4,3 \\
EFC 18 & $0,46^{(* *)}$ & 200 & 11,0 & 7,3 \\
\hline \hline
\end{tabular}

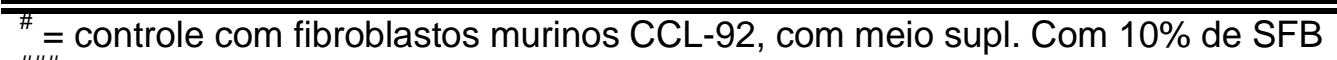

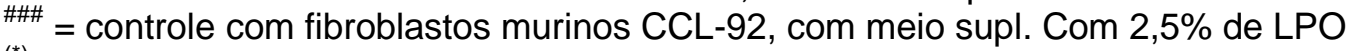

$\left.{ }^{*}\right)=$ fibroblastos humanos irradiados na dose de 200 Gy e semeados na densidade de $0,20 \times 10^{5} \mathrm{cél} / \mathrm{cm}^{2}$

${ }^{(*)}=$ fibroblastos humanos irradiados na dose de 200 Gy e semeados na densidade de $0,46 \times 10^{5} \mathrm{cé} / / \mathrm{cm}^{2}$

Para uma melhor visualização dos dados expressos nas TAB. 3, 4 e 5, estes foram compilados em gráficos, apresentados nas FIG. 29 e 30, respectivamente.

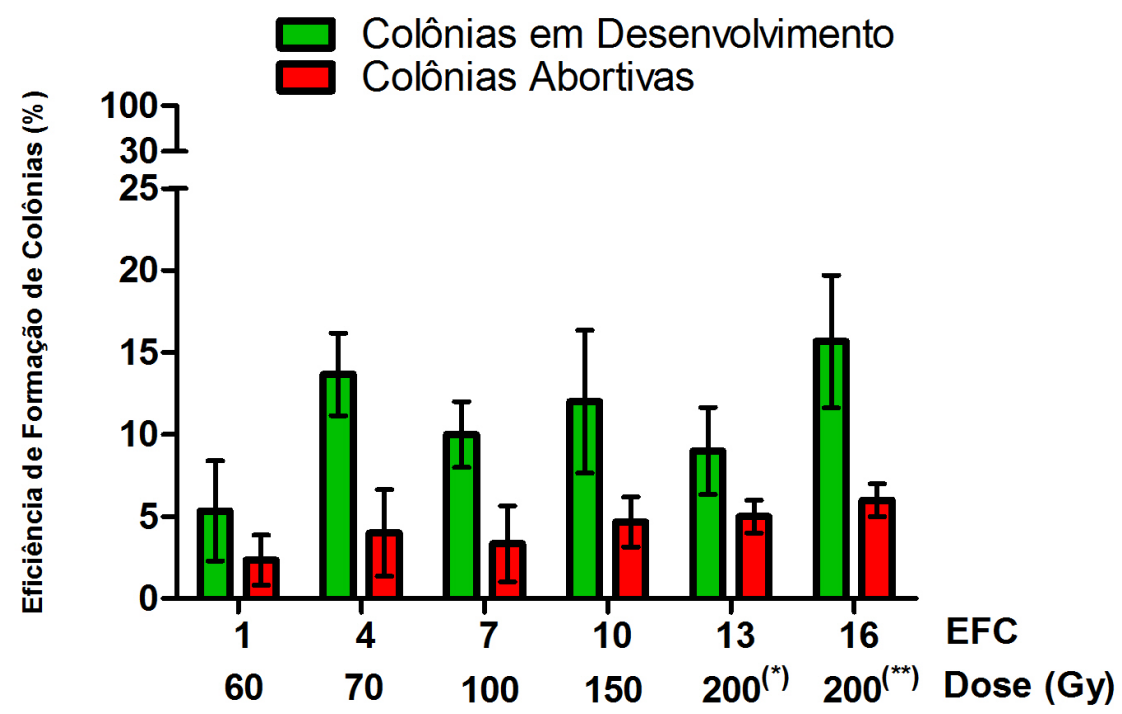

FIGURA 29 - Porcentagem de colônias em desenvolvimento e abortivas obtidas nas EFC de queratinócitos em meio de cultura suplementado com 10\% SFB, com camada de sustentação de fibroblastos humanos, nas diferentes doses de irradiação $\left(70,100,150200^{(*)}\right.$ e $\left.200^{(* *)}\right)$, respectivamente EFC 4, EFC 7, EFC 10, EFC 13 e EFC 16. Como controle, utilizou-se CCL-92 irradiado a 60 Gy (EFC 1). 

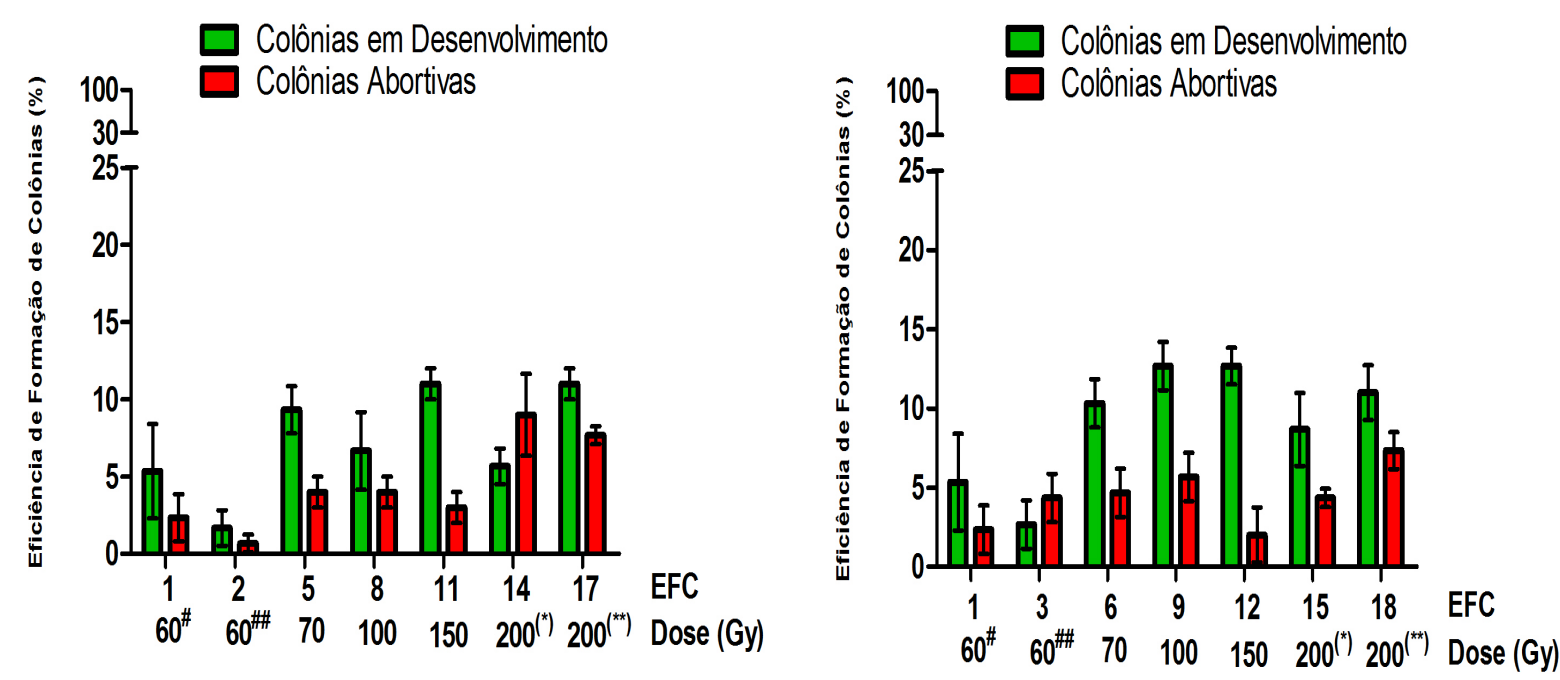

A

FIGURA 30 - Porcentagem de colônias em desenvolvimento e abortivas obtidas nas EFC de queratinócitos, com camada de sustentação de fibroblastos humanos, nas diferentes doses de irradiação 70; 100; 150; 200(*) e 200(*) Gy, respectivamente EFC 5 e EFC 6; EFC 8 e EFC 9; EFC 11 e EFC 12; EFC 14 e EFC 15; EFC 17 e EFC 18. Como controle, utilizou-se CCL-92 irradiado a 60 Gy em meio de cultura suplementado com 10\% SFB (EFC 1), 5\% LPO (EFC 2) e 2,5\% LPO (EFC 3). Suplementação do meio de cultura: A) 5\% LPO; B) $2,5 \%$ LPO.

$\mathrm{Na}$ FIG. 29, correspondente aos queratinócitos mantidos em meio e cultura suplementado com $10 \%$ de SFB, com variação da densidade da camada de sustentação composta por fibroblastos humanos irradiados nas diferentes doses, observou-se que somente as doses de 70 Gy e 200 Gy na densidade de $0,46 \times 10^{5}$ células $/ \mathrm{cm}^{2}$, foram mais eficiente quanto à porcentagem de colônias em desenvolvimento em relação ao controle murino (C). Quanto à comparação entre culturas com camada de sustentação de fibroblastos humanos, não foram observadas diferenças significativas nas porcentagens de colônias em desenvolvimento, ou nas abortivas, em nenhuma das doses de irradiação.

$\mathrm{Na}$ FIG 30, correspondente aos queratinócitos mantidos em meio de cultura suplementado com 5\% e 2,5\% de LPO, com variação da densidade da camada de sustentação composta por fibroblastos humanos irradiados nas diferentes doses, observou-se que as culturas com camada de sustentação compostas por fibroblastos murinos (C, C1 e C2) não apresentaram diferenças significativas entre si. Quanto aos fibroblastos humanos cultivados em 5\% de LPO com relação às colônias em desenvolvimento as doses de 70, 100 Gy e 200 Gy na densidade de $0,2 \times 10^{5}$ células $/ \mathrm{cm}^{2}$, se mostraram semelhantes ao controle $(\mathrm{C})$, 
já as doses de 150 Gy e 200 Gy na densidade de $0,46 \times 10^{5}$ células $/ \mathrm{cm}^{2}$ apresentaram-se mais eficientes que o controle $(C)$. Com relação à porcentagem de colônias abortivas, as doses de 70,100 e 150 Gy se mostraram semelhantes ao controle (C), enquanto que as doses de 200 Gy apresentaram maior porcentagem de colônias abortivas. Quanto aos fibroblastos humanos cultivados a $2,5 \%$ de LPO, com relação às colônias em desenvolvimento as doses de 100, 150 e 200 Gy se mostraram mais eficientes que o controle (C). Com relação às colônias abortivas, somente a dose de 200 Gy na densidade de $0,46 \times 10^{5}$ células $/ \mathrm{cm}^{2}$ apresentou maior porcentagem em relação às demais doses que se mostraram semelhantes ao controle (C).

Nas FIG 31, 32, 33 e 34, são observadas imagens fotográficas, obtidas ao microscópio óptico, dos aspectos morfológicos das diferentes camadas de sustentação em diferentes densidades e meios de cultura, e imagens macroscópicas de EFC em diferentes condições.

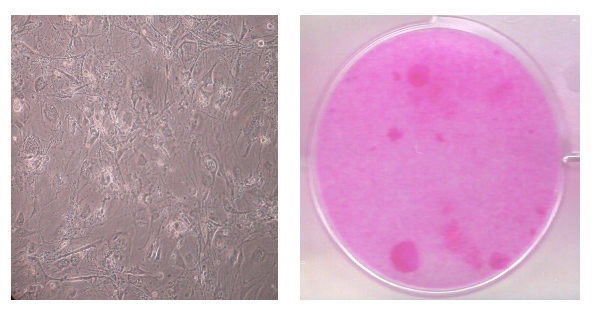

EFC 1

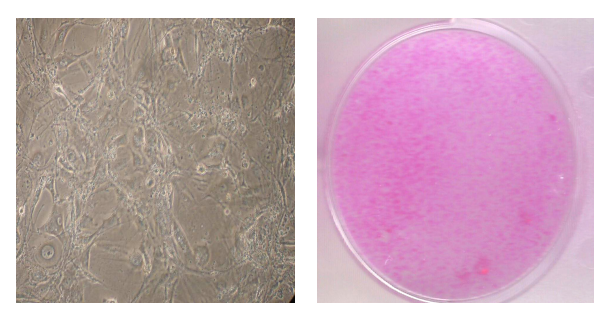

EFC 2

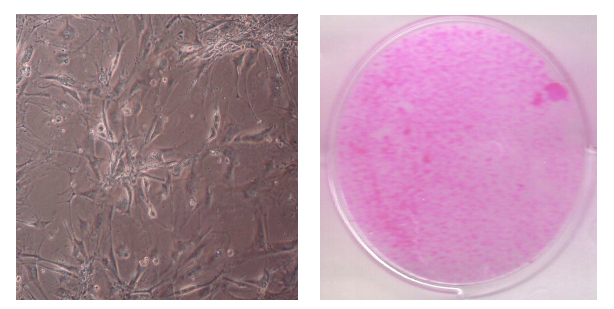

EFC 3

FIGURA 31: Fotografias de observações ao microscópio óptico (esquerda) da camada de sustentação constituída de CCL-92 e visualizações macroscópicas (direita) das EFC de queratinócitos, em meio com SFB (EFC 1), em meio com $5 \%$ LPO (EFC 2); e em meio com 2,5\% LPO (EFC 3).

Na FIG 31, observou-se que a cultura, em camada de sustentação de CCL-92, com meio contendo LPO além de apresentar um menor número de 
colônias, estas eram menos desenvolvidas. Enquanto que a cultura com meio contendo SFB apresentou maior número de colônias, sendo estas mais desenvolvidas. Em relação às imagens microscópicas, foi observada uma diminuição da quantidade de fibroblastos murinos em meio LPO, sendo que no meio contendo 2,5\% LPO verificou-se menor quantidade fibroblastos em comparação com o meio com 5\% LPO e SFB.

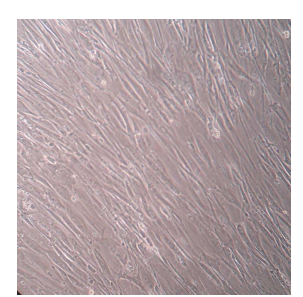

EFC 4 (70 Gy)

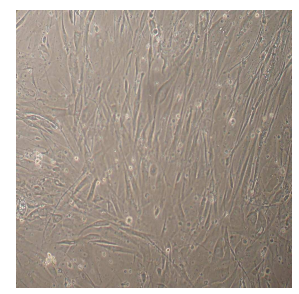

EFC 10 (150 Gy)

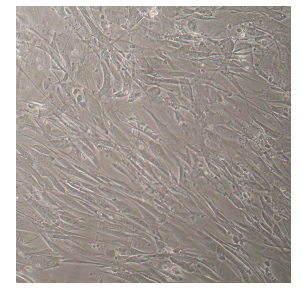

EFC 7 (100 Gy)

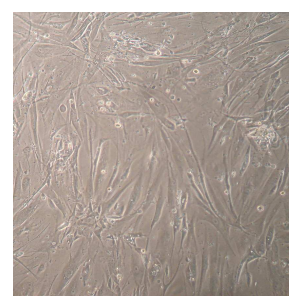

$\operatorname{EFC} 13\left(200^{(*)} \mathrm{Gy}\right)$
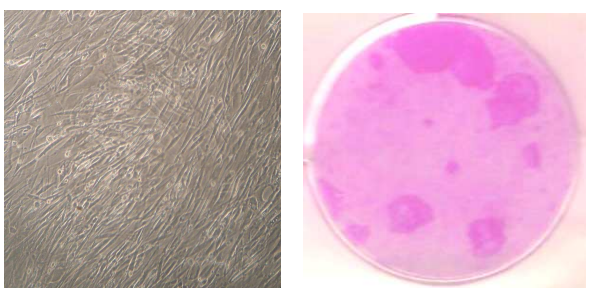

EFC $16\left(200^{(*)}\right.$ Gy)

FIGURA 32: Fotografias de observações ao microscópio óptico (esquerda) dos fibroblastos humanos, em meio com SFB, irradiados nas doses de 70, 100, 150, $200^{(*)}$ e $200^{(*)} \mathrm{Gy}$, e visualizações macroscópicas (direita) das respectivas EFC dos queratinócitos (EFC 4, EFC 7, EFC 10, EFC 13 e EFC 16).

$\mathrm{Na}$ FIG 32, nas EFC com camada de sustentação nas doses de 70 , $100,150,200^{(*)}$ e $200^{(*)}$ Gy, não foram observadas diferenças significativas com relação à quantidade de colônias, porém nas doses de 150 e $200^{(*)}$ Gy, as colônias se mostram maiores em relação às demais doses. Quanto às imagens microscópicas foram observadas que com o aumento da dose de irradiação ocorre uma diminuição significativa na quantidade de fibroblastos humanos 
irradiados, com exceção da dose de $200^{(*)}$ Gy, onde estas células foram semeadas na densidade de $0,46 \times 10^{5}$ células $/ \mathrm{cm}^{2}$.
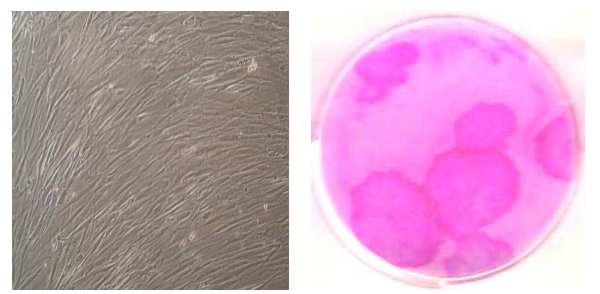

EFC 5 (70 Gy)

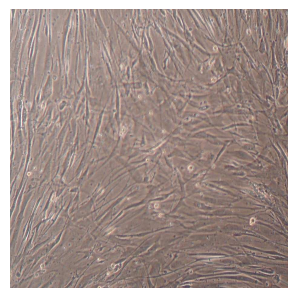

EFC 11 (150 Gy)

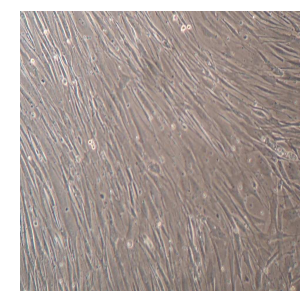

EFC 8 (100 Gy)

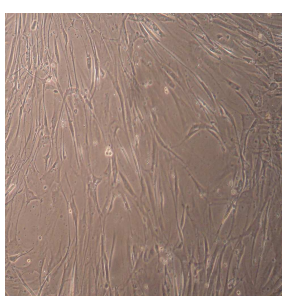

EFC $14\left(200^{(*)}\right.$ Gy)
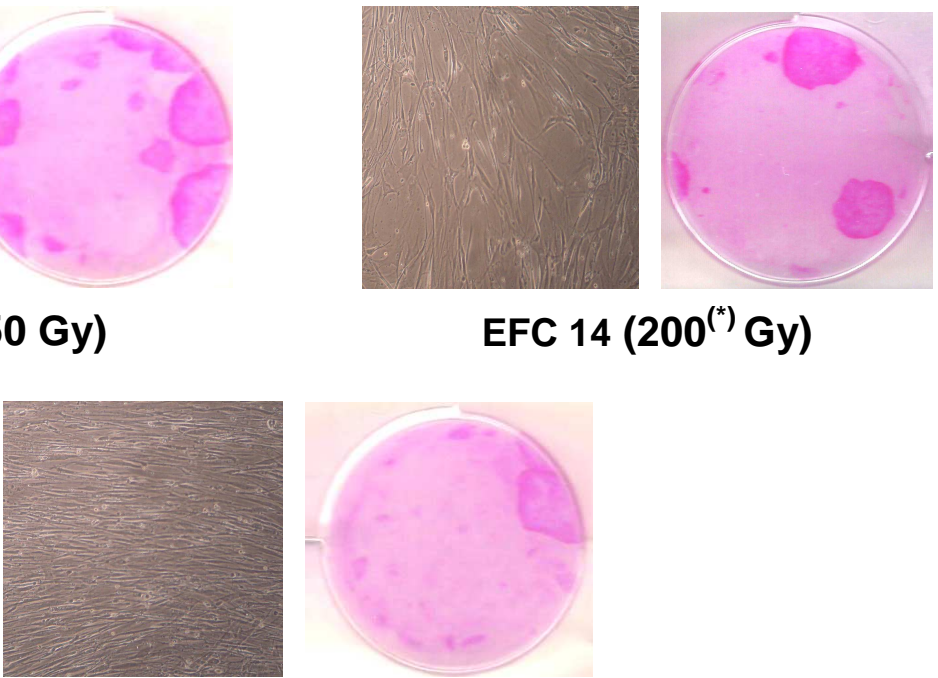

$$
\text { EFC } 17\left(200^{(* *)}\right. \text { Gy) }
$$

FIGURA 33: Fotografias de observações ao microscópio óptico (esquerda) dos fibroblastos humanos em meio com 5\% LPO, irradiados nas doses de 70, 100, $150,200^{(*)}$ e $200^{(*)}$ Gy, e visualizações macroscópicas (direita) das respectivas EFC dos queratinócitos (EFC 5, EFC 8, EFC 11 EFC 14 e EFC 17).

$\mathrm{Na}$ FIG 33, verificou-se o aparecimento de colônias em todas as doses, quando os queratinócitos foram cultivados em meio $5 \%$ LPO. Sendo que nas doses de 70, 100 e 150 Gy, as colônias apresentaram-se mais desnvolvidas do que nas demais doses. Com relação às imagens microscópicas, foi observada a manutenção de uma densa camada de sustentação nas doses de 70, 100, 150 e $200^{(*)}$ Gy, enquanto que na dose de $200^{(*)}$ Gy esta densa camada não foi observada. 


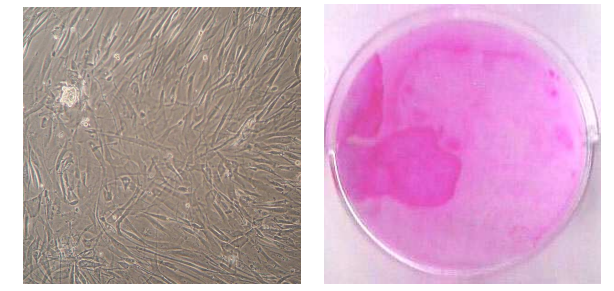

EFC 6 (70 Gy)

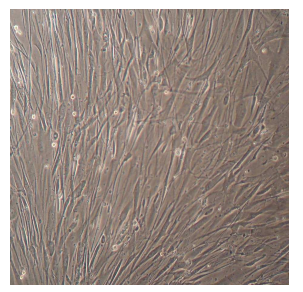

EFC 12 (150 Gy)
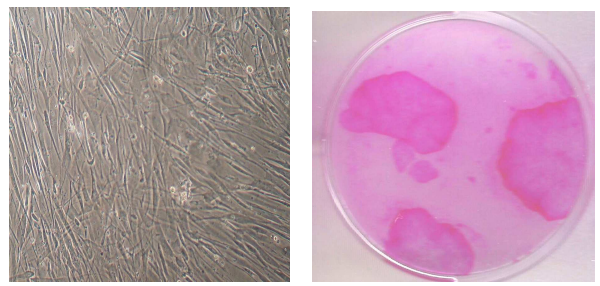

EFC 9 (100 Gy)

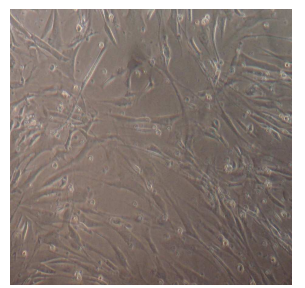

$\operatorname{EFC} 15\left(200^{(*)} \mathrm{Gy}\right)$
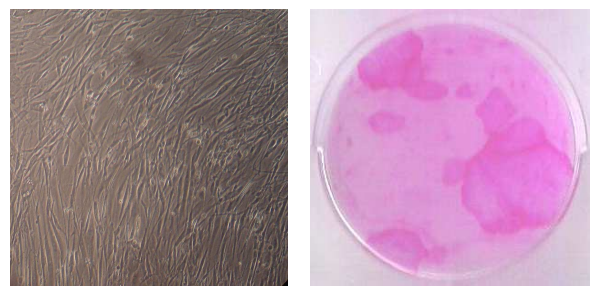

EFC $18\left(200^{(*)} \mathrm{Gy}\right)$

FIGURA 34: Fotografias de observações ao microscópio óptico (esquerda) dos fibroblastos humanos em meio com 2,5\% LPO, irradiados nas doses de 70, 100, $150,200^{(*)}$ e $200^{(*)}$ Gy, e visualizações macroscópicas (direita) das respectivas EFC dos queratinócitos (EFC 6, EFC 9, EFC 12, EFC 15 e EFC 18).

Na FIG 34, utilizando 2,5\% de LPO, observou-se o aparecimento de colônias de queratinócitos em todas as doses utilizadas para a confecção da camada de sustentação. Sendo que nas doses de 100, 150 e $200^{(*)}$ Gy, verificouse uma maior quantidade de colônias em desenvolvimento do que nas demais doses. Quanto às imagens microscópicas foi observada a presença de uma densa camada de fibroblastos humanos nas doses de 70, 100, 150 e $200^{(* *)} \mathrm{Gy}$, com exceção da dose de $200^{(*)} \mathrm{Gy}$, na qual foi verificado um desprendimento das células do fundo da placa. 


\section{Discussão}

$\mathrm{Na}$ literatura encontramos dois principais protocolos para a obtenção do lisado de plaquetas a partir do seu concentrado. O primeiro, com a utilização da trombina, que promove a desgranulação da plaquetas e liberação dos fatores de crescimento, semelhante ao que ocorre no nosso organismo. O segundo utiliza a técnica de congelamento e descongelamento promovendo a lise das plaquetas, liberando assim o seu conteúdo (Kurita et al., 2007; Blande et al. 2009). Devido a praticidade e o fato da trombina utilizada no prepado do lisado ser de origem bovina, optamos pela técnica de congelamento e descongelamento, pois 0 propósito da nossa pesquisa é substituição dos componentes xenobióticos na cultura celular. Na literatura, encontram-se várias padronizações desta última técnica, por este motivo, avaliamos o número de ciclos de congelamento e descongelamento, onde pudemos perceber o melhor tempo de congelamento foi de seis horas à $-80{ }^{\circ} \mathrm{C}$ e 15 minutos de descongelamento à $37{ }^{\circ} \mathrm{C}$, e centrifugação a $3615 \mathrm{~g}$ por 30 minutos, sendo que não seria possível reduzir o número de ciclos (quatro), pois no último ciclo ainda foi detectado um pequeno botão celular. Esta metodologia empregada para o preparo do lisado de plaquetas se mostrou eficiente, corroborando como protocolo proposto por Blande et al. (2009) que determinou como necessário, pelo menos, quatro ciclos de congelamento e descongelamento para total lise das plaquetas, e quatro ciclos de centrifugação seguida pela filtração para a obtenção de uma solução límpida.

Uma vez que a adição de heparina é necessária para evitar a formação de coágulo e gelificação do meio de cultura, e que existe divergência na literatura, quanto ao melhor momento desta adição (Blande et al., 2009; Bernardo et al., 2007), em nosso estudo foi avaliada a dose e o momento mais apropriado para adicioná-la ao concentrado de plaquetas e/ou ao meio de cultura. Para isso, a heparina foi adicionada em três momentos: antes da lise das plaquetas e durante o preparo do meio de cultura $(A)$, somente antes da lise $(B)$ ou somente durante o preparo do meio de cultura $(C)$.

Durante o preparo dos lisados plaquetas não foram observadas diferenças significativas entre as amostras herarinizadas ( $A$ e $B$ ), iguais até este momento, e amostra não heparinizada $(C)$, sendo necessário complementar estes testes com sua ação em cultura celular, para verificação da influência da heparina nos diferentes lidados (LPA, LPB e LPC). 
Fibroblastos humanos foram cultivados durante 120 horas, em meio contendo os diferentes tipos de lisados de plaquetas (LPA, LPB e LPC) na concentração de 10\%. Após 72 horas, estes apresentaram um aumento significativo $(p<0,05)$ no número de células em relação ao controle cultivado com meio de cultura suplementado com SFB (FiG. 11). Este aumento tornou-se mais evidente após 96 horas de cultura e no tempo de 120 horas podemos observar os seguintes valores: $0,72 \times 10^{5} \pm 0,34 \times 10^{4}$ (SFB); $2,5 \times 10^{5} \pm 3,4 \times 10^{4}$ (LPA); 2,8 $\times$ $10^{5} \pm 5,3 \times 10^{4}$; (LPB); $2,2 \times 10^{5} \pm 2,1 \times 10^{4}$ (LPC). Segundo Barbieri et al. (2004), o PDGF liberado pelas plaquetas, é capaz de estimular a síntese de DNA e o crescimento celular dos fibroblastos in vitro, uma vez que estas células possuem receptores $(\alpha$ e $\beta$ ) para PGDF. Sendo assim podemos deduzir que os meios suplementados com lisado de plaquetas contem fatores mitogênicos que proporcionaram uma melhor proliferação do que os componentes encontrados no SFB. Não foram encontradas diferenças significativas entre os diferentes lisados, nos intervalos analisados. Isto mostra que a adição de heparina antes e/ou depois no preparo dos lisados não interferiu na proliferação dos fibroblastos. Nesse ensaio também foi observado que os fibroblastos cultivados em meio com LP ou com SFB apresentaram diferenças morfológicas quando comparadas entre si (FiG. 12). As células cultivadas com os lisados apresentaram-se menores e com citoplasma mais definido, semelhantes os fibroblastos mitoticamente ativos encontrado por Bayreuther e col. (1988), enquanto os mesmos cultivados com SFB pareceram semelhantes com as células pós-mitóticas irreversíveis (vide FIG. 3 , em revisão da literatura). Podemos assim, inferir que os lisados de plaquetas não induziram a diferenciação dos fibroblastos humanos e proporcionaram a duplicação destes em um tempo mais curto do que os cultivados com SFB.

Além de analisar a proliferação celular dos fibroblastos humanos, em meios contendo lisados de plaquetas, verificou-se a influência destes na adesão celular, conforme é ilustrado na FIG .13. Resultados revelam em todos os meios de cultura, LPA, LPB, LPC e CS, testados na concentração de $10 \%$, que a viabilidade celular foi significativamente maior $(140 \%, p<0,05)$, do que no controle (SFB). O mesmo comportamento é observado nas concentrações mais baixas de lisado de plaquetas (2,5\% e 5\%), onde as viabilidades foram em torno de $130 \%$ a $140 \%$. Embora, o CS seja utilizado para cultura de fibroblastos murinos, este também se mostrou melhor para adesão dos fibroblastos humanos do que SFB, 
proporcionando uma viabilidade de $126 \% \pm 2,8 \%$. Contudo, quando comparado com os lisados de plaquetas a 10\%, o CS apresentou viabilidade estatisticamente menor $(p<0,05)$. Morfologicamente foi possível observar modificações dos fibroblastos, de acordo com o aumento da concentração de LP, sendo que na menor concentração $(2,5 \%)$ os fibroblastos se mostraram semelhantes aos cultivados com SFB (FIG. 14), fato que parece demonstrar que nas concentrações mais baixas $(2,5 \%)$, a quantidade de fatores de crescimento e proteínas presentes nas plaquetas, responsáveis pela adesão celular, não foram suficientes para promover uma adesão semelhante às concentrações mais altas (10\%).

Quanto à viabilidade celular, foi observado que após 24 horas (FIG. 15), a maioria das culturas mantidas em meios com lisados apresentaram uma viabilidade superior ao controle, com exceção de LPA (5\%) e LPC (10\%), que se mostram inferiores ao controle. Após 48 horas (FIG. 16), observou-se, uma queda na viabilidade celular, nas culturas cultivadas com lisados de plaquetas a 2,5\%, obtendo-se os valores $81,6 \% \pm 4,8 \%$ (LPA), $77,9 \% \pm 8,4 \%$ (LPB) e $80,8 \% \pm 5,5 \%$ (LPC). Nas concentrações de $5 \%$, LPB e LPC apresentaram viabilidades estatisticamente superiores $(p<0,05)$ ao controle, o mesmo não ocorreu com LPA, no qual não foi observada diferença significativa $(p>0,05)$ em relação ao controle. Quanto às concentrações de $10 \%$, verificou-se um aumento significativo $(p<0,05)$ em relação ao controle, obtendo-se viabilidade de 129,4\% \pm 17,4\% (LPA), $135,7 \%$ $\pm 12,7 \%$ (LPB) e $143,0 \% \pm 10,7 \%$ (LPC). Nos tempos de 72 (FIG. 17) e 96 horas (FIG 18), verificou-se que somente as culturas contendo $10 \%$ dos lisados apresentaram uma viabilidade estaticamente superior ao controle. Ainda que nos lisados a 5\% notou-se um rendimento semelhante ao controle após 72 horas de contato, o mesmo não foi observado após 96 horas.

Analisando os resultados, verificou-se que a concentração ideal, de lisado de plaquetas no meio de cultura, deve ser de $10 \%$. Nesta concentração, encontra-se uma quantidade suficiente de citocinas e fatores de crescimento que estimulam ótimo desenvolvimento para os fibroblastos, inclusive superior ao obtido com meio de cultura contendo $10 \%$ de SFB.

Estes resultados confirmaram os dados relatados por Krasna et al. (2007) e Bernardo et al. (2007) que, ao cultivarem diferentes tipos celulares em várias concentrações de lisado, verificaram que as células proliferam de maneira dose dependente. 
Quanto à observação microscópica, não foram verificadas diferenças morfológicas entre os fibroblastos cultivados em meios com os diferentes lisados, em nenhuma das concentrações estudadas (2,5\%, 5\% e 10\%). Uma vez que estes já se encontravam confluentes no tempo de 24 horas (FIG. 19).

Os testes de adesão e viabilidade celular nos diferentes tempos foram realizados concomitantemente, nas mesmas condições, afim de, compará-los. Portanto, não foi possível reduzir o número inicial de fibroblastos semeados para ambos experimentos. Ainda assim, observou-se que a concentração de $10 \%$ de lisado de plaquetas proporcionou melhores condições para o desenvolvimento de fibroblastos, sendo que não foram verificadas diferenças significativas $(p>0,05)$ entre os lisados LPA, LPB e LPC a $10 \%$.

Uma análise comparativa dos fibroblastos cultivados em meios contendo lisados de plaquetas provenientes dos tipos sanguíneos $A, B, A B, O$ e Pool (união dos tipos sanguineos), (LA, LB, LAB, LO e LPool, respectivamente), não evidenciaram diferenças significativas $(p>0,05)$ entre si, quanto a adesão celular (FIG. 20). O mesmo foi verificado nas observações feitas ao microscópio óptico, no qual não foram constatadas diferenças morfológicas (FIG. 21).

Ao avaliar o desenvolvimento celular dos fibroblastos humanos cultivados na presença de lisados de plaquetas, provenientes de diferentes tipos sanguíneos, verificou-se que todos os lisados apresentaram um desenvolvimento superior ao controle (SFB), nos tempos analisados (24, 48, 72 e 96 horas). No entanto, ao analisar os lisados entre si foram verificadas diferenças significativas $(p<0,05)$ nos tempos de 48,72 e 96 horas, sendo que os lisados do tipo $A B, O$ e Pool foram os que proporcionaram melhor viabilidade celular em relação aos demais (FIG. 22 a 25). Pode-se concluir que a união de todos os tipos sanguíneos não prejudicou o desenvolvimento dos fibroblastos, inclusive proporciononando um incremento a este desenvolvimento. Este fato pode ser importante na reprodutibilidade de experimentos in vitro, podendo ser utilizado o mesmo Pool de lisado para uma série de experimentos comparativos.

Nas observações microscópicas foram verificadas modificações na morfologia dos fibroblastos, em relação ao controle. Nos cultivados com SFB, as células se mostraram maiores e mais alongadas, enquanto que nos cultivados com lisados, estas se apresentaram menores e mais arrendondadas. Não foram 
observadas diferenças morfológicas nas culturas cultivadas com os diferentes lisados (FIG. 26).

Apesar de detectarmos diferenças na influencia do tipo sangüíneo no desenvolvimento dos fibroblastos em cultura, devemos ressaltar que para a utilização clínica, estas células devem ser cultivadas preferencialmente, em meio de cultura enriquecido com lisado de plaquetas do próprio paciente, com a finalidade de evitar a transmissão de patógenos e desencadeamento da resposta imune contra o mesmo.

Buscando uma inativação da proliferação de fibroblastos e não a morte celular, visto que estes são utilizados como camada alimentadora e de sustentação para o crescimento de queratinócitos, estes foram irradiados com diferentes doses (variando de 60 a $300 \mathrm{~Gy}$ ), com a finalidade de determinar qual a dose ideal para inativar a sua proliferação (FIG. 27). Foi observado que até o terceiro dia, as células irradiadas e não irradiadas apresentavam o mesmo número de células vivas do dia da semeadura (dia zero). Mudanças só foram verificadas no sétimo dia, onde pudemos perceber que fibroblastos humanos não irradiados continuaram a se multiplicar, enquanto que os mesmos irradiados mantiveram aproximadamente o mesmo número de células viáveis. O mesmo comportamento não ocorreu para os fibroblastos murinos, no qual foi verificada uma diminuição no número de células viáveis ao longo dos 14 dias. Estes resultados corroboram com dados reportados por Almeida et al., 2007.

Para mimetizar o que ocorreria na cultura dos queratinócitos em camada de sustentação, fibroblastos murinos e humanos foram acondicionados em meio próprio para queratinócitos. Assim, verificou-se que a presença de adenina, que tem ação de inibir a proliferação dor fibroblastos (Breidal et al., 1989), retardou a duplicação dos fibroblastos humanos irradiados e os não irradiados, justificando o aumento de células viáveis somente após o sétimo dia. Esses dados sugerem que os fibroblastos humanos demoraram até este período para se adaptar com o meio em que foram acondicionados. Após o sétimo dia, verifica-se que os fibroblastos humanos não irradiados continuam a duplicar sucessivamente até o décimo quarto dia.

Embora Maas-Szabowski et al. (2000) afirmem que na dose de 70 Gy os fibroblastos humanos interrompem a sua duplicação, esse fato não foi observado nas nossas condições, onde observamos um ligeiro aumento entre o 
terceiro e sétimo dia, e posterior manutenção do número de células viáveis. Obtivemos uma contagem de aproximadamente $3 \times 10^{4} \pm 2 \times 10^{3}$ células no dia zero para $70 \mathrm{~Gy}$, no dia 7 o número de células contadas foi para $4 \times 10^{4} \pm 2,6 \mathrm{x}$ $10^{3}$. O mesmo foi verificado para as demais doses. Entretanto, após o sétimo dia, não foi observado aumento e nem diminuição no número de células até o último dia do ensaio. Não se verificou diferença significativa $(p>0,05)$ no número de células viáveis, nas culturas dos fibroblastos irradiados no intervalo de doses que variou de 60 a 300 Gy, durante o período em que foi executado o ensaio. Constatando a possibilidade da utilização de qualquer uma dessas doses para inativação dos fibroblastos humanos.

Por meio de análise microscópica da FIG. 28, verifica-se um aumento do número de fibroblastos humanos (irradiados e não irradiados) a partir do sétimo dia em relação ao dia zero, confirmando assim um aumento da contagem celular (FIG. 27). Nos fibroblastos murinos e humanos irradiados a $300 \mathrm{~Gy}$, observa-se o aparecimento de espaços entre as células, sugerindo a morte e 0 desprendimento de algumas destas. Nas demais doses, verifica-se uma densa camada de fibroblastos, intacta. Segundo Limat et al. (1989), fibroblastos humanos mitoticamente inativado por irradiação ou Mitomicina $C$ podem ser mantidos em cultura até pelos menos 4 semanas sem perder a sua eficiência como camada de sustentação.

Utilizando o teste de eficiência de formação de colônias, avaliou-se a influência dos diferentes tipos de camada de sustentação, densidade e suplementação do meio de cultura, no desenvolvimento dos queratinócitos.

Com este objetivo, mantivemos inicialmente o meio com $10 \%$ SFB com variação da camada de sustentação composta por fibroblastos murinos e humanos irradiados nas diferentes doses (TAB. 3). Neste experimento, quando observadas as culturas de queratinócitos sobre as camadas de sustentação obtidas com as doses de 100, 150 e $200^{(*)}$ Gy, nota-se semelhança na porcentagem de colônias, tanto em desenvolvimento e quanto as abortivas, com os tipos correspondentes no controle constituído por camada de sustentação de origem murina irradiado a 60 Gy. No entanto, quando observadas as culturas nas doses de 70 e $200^{(*)}$ Gy, verifica-se um aumento na porcentagem de colônias em desenvolvimento, já com relação às colônias abortivas a porcentagem se mantém semelhante ao controle e demais doses (FIG. 29). Os resultados supracitados 
divergem com os relatados por Rheinwald e Green (1975), onde estes autores verificaram que queratinócitos cultivados com fibroblastos humanos crescem mais lentamente do que quando cultivados com fibroblastos murinos, porém a principal diferença entre os dois ensaios, é que no nosso caso utilizamos um tipo de SFB padronizado, o soro fetal clone III que é utilizado para diversos tipos de linhagens celulares, possibilitando assim o desenvolvimento dos queratinócitos cultivados com fibroblastos humanos irradiados.

Ainda em relação a estas culturas podemos visualizar na FIG. 32, nas EFC com camada de sustentação nas diversas doses, especialmente nas doses de 150 e 200 (*) Gy, o surgimento de colônias de queratinócitos maiores em relação às demais doses. Nas imagens microscópicas, nas doses de 150 e $200^{(*)}$ Gy, verifica-se uma diminuição na quantidade de fibroblastos humanos o que possibilitou melhor desenvolvimento de colônias de queratinócitos, isso é devido a influência da densidade na camada de sustentação. Segundo Rheinwald e Green (1975), este é um fator primordial para o desenvolvimento dos queratinócitos em colônia.

Resultados inesperados, se comparados aos achados de Rheinwald e Green (1975), podem ser observados na FIG. 30, na qual são visualizadas culturas de queratinócitos mantidos em meio suplementado com 2,5\% e 5\% LPO com variação da densidade da camada de sustentação composta por fibroblastos humanos irradiados em diferentes doses (TAB. 4 e 5), estas culturas quando em meio contendo 5\% LPO, com relação a porcentagem de colônias em desenvolvimento apresentaram-se semelhantes ao controle (C). No entanto, tratando-se da porcentagem de colônias abortivas, o meio com 5\% LPO mostrouse menos eficiente que o controle $(C)$. As culturas com meio contendo 2,5\% LPO apresentaram-se mais eficientes que o controle $(C)$ com relação à porcentagem de colônias em desenvolvimento, para as doses 100, 150 e $200^{(*)}$ Gy, quando comparada a porcentagem de colônias abortivas, estas se mostraram semelhantes ao controle (C). Podemos assim entender que as culturas com meio contendo 2,5\% LPO já possuem quantidades de fatores de crescimento suficientes para proporcionarem melhor desenvolvimento dos queratinócitos em relação às culturas mantidas com $10 \%$ SFB.

Nas EFC dos queratinócitos cultivados em fibroblastos irradiados na dose de 200 Gy, só foi observado um aumento na porcentagem de colônias em 
desenvolvimento e abortivas comparadas com o controle $(C)$, quando estes foram semeados em uma densidade superior $\left(0,46 \times 10^{5}\right.$ células $\left./ \mathrm{cm}^{2}\right)$ à utilizada para as outras doses, provavelmente por que parte destas células não aderem à superfície da placa.

Observações macroscópicas (FIG. 33 e 34) possibilitam a visualização de colônias em todas as camadas de sustentação, nas diferentes doses, sendo que nas doses de 70, 100 e 150 Gy nas culturas com meio contendo 2,5\% e 5\% LPO estas colônias apresentam-se maiores e de formato regular. Com relação às observações microscópicas, nas culturas com meio contendo 2,5\% e 5\% LPO, pode-se observar a manutenção da camada de sustentação nas doses de 70, 100, 150 e $200^{(*)}$ Gy, enquanto que na dose de $200^{(*)}$ Gy foi verificado um desprendimento das células do fundo da placa.

Analisando os resultados acima, pode-se inferir que os fibroblastos humanos irradiados em qualquer uma das doses estudadas, demonstraram possuir boas condições para o cultivo de queratinócitos em meio contendo 2,5\% LPO. Uma vez que nestas condições é possível verificar um maior número de colônias em desenvolvimento em comparação com as demais condições. 


\section{Conclusão}

Foi possível padronizar, tanto o cultivo dos fibroblastos humanos em meio de cultura enriquecido com lisado de plaquetas, quanto sua inativação para utilização como camada de sustentação na cultura de queratinócitos, de maneira a eliminar os componentes xenobióticos.

Para possibilitar esta padronização, as modificações obtidas foram:

O protocolo de congelamento/descongelamento (seis horas à $-80{ }^{\circ} \mathrm{C} / 15$ minutos à $37^{\circ} \mathrm{C}$ ), e centrifugações ( $3615 \mathrm{~g}$ por 30 minutos), seguido pela filtração, permitiu a obtenção de um lisado de plaquetas, sem coágulos e debris. Optandose pela adição de $100 \mathrm{UI}$ de heparina / $\mathrm{mL}$ concentrado de plaquetas, diretamente na bolsa de coleta, antes do início da lise.

A substituição do soro fetal bovino por lisados de plaquetas no meio de cultura proporcionou uma melhor adesão e proliferação dos fibroblastos humanos, sendo que a maior viabilidade celular foi obtida com a concentração de $10 \%$ de lisado.

É possível a utilização da combinação de lisados de diferentes tipos sanguíneos no desenvolvimento dos fibroblastos em culturas, para os testes in vitro. Lembrando que é imprescindível a utilização do lisado de plaquetas autólogas (ou seja, do próprio paciente), no meio de cultura para células a serem cultivadas para uso clínico.

Em todas as doses testadas (60 a $300 \mathrm{~Gy}$ ), os fibroblastos humanos tiveram as suas atividades mitóticas inativadas pela radiação, mantendo-se viáveis até quatorze dias após irradiados.

As culturas de queratinócitos humanos podem ser desenvolvidas satisfatoriamente em camada de sustentação de fibroblastos humanos irradiados de 70 a 150 Gy, semeada na densidade de $0,2 \times 10^{5}$ células $/ \mathrm{cm}^{2}$, com melhor desempenho em meio contendo $2,5 \%$ de lisado de plaquetas humanas. 


\section{APÊNDICE A - Preparo das EFC nas diferentes condições.}

\begin{tabular}{ccccc}
\hline \hline $\begin{array}{c}\text { Classificação } \\
\text { das EFC }\end{array}$ & Fibroblastos & $\begin{array}{c}\text { Camada de sustentação } \\
\text { Densidade } \\
\left(10^{5} \text { cél/ } \mathrm{cm}^{2}\right)\end{array}$ & $\begin{array}{c}\text { Dose } \\
(\mathrm{Gy})\end{array}$ & $\begin{array}{c}\text { Suplemento } \\
\text { do meio de } \\
\text { cultura }\end{array}$ \\
\hline EFC 1 & CCL-92 & 0,26 & 60 & $10 \%$ SFB \\
EFC 2 & CCL-92 & 0,26 & 60 & $5 \%$ LPO \\
EFC 3 & CCL-92 & 0,26 & 60 & $2,5 \%$ LPO \\
EFC 4 & Humano & 0,2 & 70 & $10 \%$ SFB \\
EFC 5 & Humano & 0,2 & 70 & $5 \%$ LPO \\
EFC 6 & Humano & 0,2 & 70 & $2,5 \%$ LPO \\
EFC 7 & Humano & 0,2 & 100 & $10 \%$ SFB \\
EFC 8 & Humano & 0,2 & 100 & $5 \%$ LPO \\
EFC 9 & Humano & 0,2 & 100 & $2,5 \%$ LPO \\
EFC 10 & Humano & 0,2 & 150 & $10 \%$ SFB \\
EFC 11 & Humano & 0,2 & 150 & $5 \%$ LPO \\
EFC 12 & Humano & 0,2 & 150 & $2,5 \%$ LPO \\
EFC 13 & Humano & 0,2 & 200 & $10 \%$ SFB \\
EFC 14 & Humano & 0,2 & 200 & $5 \%$ LPO \\
EFC 15 & Humano & 0,2 & 200 & $2,5 \%$ LPO \\
EFC 16 & Humano & 0,46 & 200 & $10 \%$ SFB \\
EFC 17 & Humano & 0,46 & 200 & $5 \%$ LPO \\
EFC 18 & Humano & 0,46 & 200 & $2,5 \%$ LPO \\
\hline \hline
\end{tabular}




\section{ANEXO A - Aprovação do Comitê de Ética em Pesquisa (COEP)}

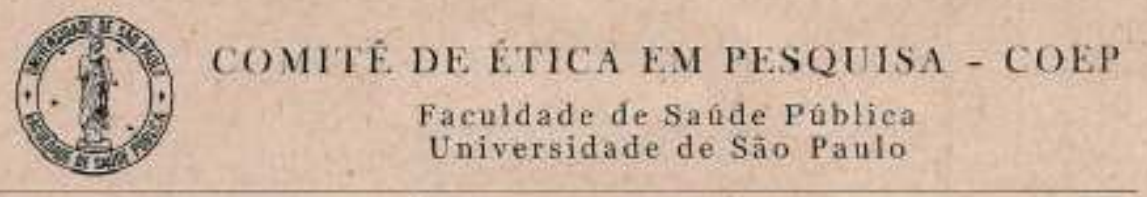

OF.COEP $/ 448 / 10$

17 de dezembro de 2010

Prezadas nesquicadoras e onentadora

a Comité de Etica em Pesquisa da Faculdade de Saúde Püblica da Universidade de Säo Pauto - COEP analisou de acordo com a Resolucáo n * 196/96 do Conselho Nacional de Saúde CNS e suas complementares, o protocolo de pesquisa n: 2177 , intitulado 'SUBSTITUICÁO DOS COMPONENTES XENOBIOTICOS DAS CULTURAS DE FIBROBLASTOS E QUERATINOCITOS HUMANOS", área tematica GRUPO III, sob responsabilidade das pesquisadoras Daniele Yoshito e Silvana Cereijido Altran e orientaçáo da Doutora Monica Beatriz Mathor, considerando-0. APROVADO "AD REFERENDUM":

Cabe lembrar que, conforme a Resoluçäo CNS 196/96, sāo deveres do(a) pesquisadorła): 1. Comunicar de imediato qualquer alteraçao no projeto e aguardar manifestasảo deste Comité de Litica $\mathrm{rm}$ Pesquisa paid dar continuidade a pesquisa, 2. Manter sob sua guarda e em local secume, Delo prazo de 5 (cinco) anos, os dados da pesquisa, contendo fichas individuais e todos os demais documientos recomendados pelo COEP, no caso eventual auditoria; 3 . Comunizar, formaimente a este Comité quando houver a encerramenta da pesquisa; 4. Elaborar e apresentaf telatónios parriais o final, 5. lustificar perante o COEP internupḉo do projeto ou a mão publicasáo dos resiltados

Atenciosamente

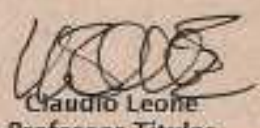

Professor Titular

Coordenador do Comité de Etica em Pesquisa - FSP/USP

Ilima: $5 r a$

Dra. Monica Beatriz Mathor

Centro de Tecnologia das Radiacōes-CIR

Instituto de Pesquisas Energèticas e Nucleares - IPENVCNEN-SP 


\section{REFERÊNCIAS BIBLIGÁFICAS}

ALBERTS, B.; JOHSON, A.; LEWIS, J.; RAFF, M.; ROBERTS, K.; WALTER, P. Biologia molecular da célula. 5. ed. Porto Alegre: Artmed, 2010.

ALDÉN, A.; GONZALES, L.; PERSSON, A.; CHRISTENSSON, K.; HOLMQVIST, O.; OHLSON, S. Porcine platelet lysate as supplement for animal cell culture. Cytotechnology, v. 55, n. 1, p. 3-8, 2007.

ALITALO, K.; KUISMANEN, E.; MYLLYLA, R.; KIISTALA, U.; ASKO-

SELJAVAARA, S.; VAHERI, A. Extracellular matrix proteins of human epidermal keratinocytes and feeder 3 T3 cells. J. Cell Biol., v. 94, n. 3, p. 497-505, 1982.

ALMEIDA, T.L.; KLINGBEIL, M.F.G.; YOSHITO, D.; HERSON, M.R.; CAPRONI, P., MATHOR, M.B., Irradiated murine fibroblasts feeder layer used in human cell cultured. In: 2007 International Nuclear Atlantic Conference, 2007, Santos, 2007. Proceedings of 2007 International Nuclear Atlantic Conference, INAC 2007. Rio de Janeiro: Associação Brasileira de Energia Nuclear- ABEN, 2007.

ANDREASSI, L. History of keratinocyte cultivation. Burns, v. 18, n. 1, p. s2-s3, 1992. Suplemento 1.

ATIYED, B.S.; COSTAGLIOLA, M. Cultured epithelial autograft (CEA) in burn treatment: three decades later. Burns, v.33, n.4, p. 405-413, 2007.

ATOMIC ENERGY OF CANADA LIMITED. Instruction manual - Gammacell 220 - Cobalt 60 irradiation unit. 6. ed. Ottawa: [s. n.], 1968.

ÁVILA, R.I. El descubrimiento de las plaquetas. Rev. Biomed., v.8, n. 3, p.197208, 1997.

BARBIERI, C.M.O; COSTA, P.I. Fator de crescimento derivado de plaquetas humanas obtidos por uma metodologia rápida e de baixo custo. Ver. Ciênc. Farm., v. 25, n. 2, p. 129-134, 2004.

BARRANDON, Y. The epidermal stem cell: an overview. Dev. Biol., v. 4, n. 4, p. 209-215, 1993.

BARRANDON, Y.; GREEN, H. Three clonal types of keratinocyte with different capacities for multiplication. Proc. Natl. Acad. Sci. USA, v.84, n. 8, p. 2302-2306, 1987

BARRECA, A.; DE LUCA, M.; DEL MONTE, P.; BONDANZA, S.; DAMONTE, G.; CARIOLA, G. DI MARCO, E.; GIORDANO, G.; CANCEDDA, R.; MINUTO, F. In vitro paracrine regulation of human keratinocyte growth by fibroblast-derived insulin-like growth factors. J. Cell. Physiol., v. 151, n. 2, p. 262-268, 1992. 
BAYREUTHER, K.; RODEMANN, H.P.; HOMMEL, R.; DITTMANN, K.; ALBIEZ,M.; FRANCZ, P.I. Human skin fibroblasts in vitro differentiate along a terminal cell lineage. Proc. Natl. Acad. Sci. USA, v. 85, n. 14, p. 5112-5116, 1988.

BERNARDO, M.E.; AVANZINI, M.A.; PEROTTI, C.; COMETA, A.M.; MORETA, A.; LENTA, E.; DEL FANTE, C.; NOVARA, F.; DE SILVESTRI, A.; AMENDOLA, G.; ZUFFARDI, O. Optimization of in vitro expasion of human multipotent mesenchymal stromal cells for cell-therapy approaches: further insights in the search for fetal calf serum substitute. J. Cell. Physiol., v. 211, n.1, p.121-130, 2007.

BLANDE, I.S.; BASSANEZE, V.; LAVINI-RAMOS, C.; FAE, K.C.; KALIL, J.; MIYAKAWA, A.A.; SCHETTERT, I.T.; KRIEGER, J.E. Adipose tissue mesenchymal stem cell expansion in animal serum-free medium supplemented with autologous human platelet lysate. Transfusion, v. 49, n.12, p. 2680-2685, 2009.

BREIDAL, A.F.; JUDSON, R.T.; CLUNIE, G.J.A. Review of keratinocyte culture techniques: problems of growing skin. Aust. N. Z. J. Surg., v.48, n. 2, p. 159-168, 1989.

BRUNNER, D.; FRANK, J.; APPL, H.; SCHÖFFL, H.; PFALLER, W.; GSTRAUNTHALER, G. Serum-free cell culture: the serum-free media interactive online database. ALTEX, v. 27, n. 1, p. 53-62, 2010.

BULLOCK, A.J.; HIGHAM, M. C.; MACNEIL, S. Use of human fibroblasts in the development of a xenobiotic-free culture and delivery system for human keratinocytes. Tissue Engineering, v. 12, n. 2, p. 245-255, 2006.

CARREL A.; BURROWS M.T. Cultivation of adult tissues and organs outside the body. JAMA., v. 55, n. 16, p. 1379-1381, 1910.

CASTRO, H.C.; FERREIRA, B.L.A.; NAGASHIMA, T.; SCHUELER, A.; RUEFF, C.; CAMISASCA, D; MOREIRA, G.; SCOVINO, G.; BORGES, L.; LEAL, M.; FILGUEIRA, M.; PASCHOAL, P.; BERNADO, V.; BOURGUINHOH, S.; RODROGUES, C.R.; SANTOS, D.O Plaquetas: ainda um alvo terapêutico. J. Brás. Patol. Med. Lab., v. 42, n. 5, p. 321-332, 2006.

CNEN - Comissão nacional de Energia nuclear. Radiotividade. Disponível em: <htpp://www. Cnen.gov.br/ensino/apostilas/radio,pdf>. Acesso em: 20 nov. 2010.

COLLI, C.; MESQUITA, C.H. Biossegurança no uso de radioisótopos. In: HIRATA, M.H.; MANCINI FILHO, J. Manual de Biossegurança. São Paulo, Manole, 2002. Cap. 8. p. 201-246.

COOLEN, A.N.; ULRICH, M.M.W; MIDDELKOOP, E. Future perspectives of tissue-engeered skin: xenobiotic-free culture systems. Tissue Engineering, v.1, p. $432-437,2010$. 
CRISTOVAM, P.C.; GLORIA, M.A.; MELO, G.B.; GOMES, J. A. P. Importância do co-cultivo com fibroblastos de camundongo 3T3 para estabelecer cultura de suspensão de células epiteliais do limbo humano. Arq. Bras. Oftalmol., v. 71, n. 5, p. 689-694, 2008.

DAHLAN, K.Z.M. Radiation Sciences. In: PHILIPS, G.O.; NATHER, A. Advances in tissue banking v. 5 The Scientific basis if Tissues Transplantation World Scientific, 2001.

DE LUCA, M.; ALABANESE, E.; CANCEDDA, R.; VIACAVA, A.; FAGGIONI, A.; ZAMBRUNO, G.; GIANNETTI, A. Treatment of leg ulcers with cryopreserved allogenic cultured epithelium. Arch. Dermatol., v. 128, n. 5, p. 633-638, 1992.

DE LUCA, M.; CANCEDDA, R. Culture of human epithelium. Burns, v. 18, n. 1, p. s5-s10, 1992. Suplemento 1.

EASTMENT, C.T.; SIRBASKU, D.A. Human platelet lysate contains growth factor activities for established cell lines derived from various tissues of several species. In Vitro, v. 16, n.8, p. 694-705, 1980.

EVERTS, P.A.M.; KNAPE, J.T.A.; WEIBRICH, G.; SCHÖNBERGER, J.P.A.M.; HOFFMANN, J.; OVERDEVEST, E.P.; BOX, H.A.M.; VAN ZUNDERT, A. Plateletrich plasma and platelet gel: a review. J. Extra. Corpor. Technol., v. 38, n.2, p. 174-187, 2006.

FRESHNEY, R.I. Introduction. In: FRESHNEY, R.I. Culture of epithelial cells. New York: wiley-liss, 2002, p. 1-30.

GARTNER, L.P.; HIATT, J. Tratado de histologia em cores. 3. ed. Rio de Janeiro: Elsevier, 2007.

GREEN, H.; KEHINDE, O.; THOMAS, J. Growth of cultured human epidermal cells into multiple epithelia suitable for grafting. Proc. Nalt. Acad. Sci. USA, v. 76, n. $11,1979$.

GREEN, J.; RHEINWALD, J.M.; SUN, T.T.; Properties of an epithelial cell types in culture: the epidermal keratinocyte and its dependence on products of the fibroblast. Prog. Clin. Biol. Res., v. 17, p. 493-500, 1977.

HARRIS, M.I.N.C. Pele: estrutura, propriedades e envelhecimento. 3. ed. São Paulo: Senac, 2009.

HARRISON, P.; CRAMER, E.M. Platelet alpha-granules. Blood Rev., v. 7, n. 1, p. 52-62, 1993.

HERSON, M.R. Estudo da composição in vitro de substituto cutâneo dermoepidérmico constituído por epitélio de queratinócitos cultivados sobre base dérmica alógena. 1999. Tese (Doutorado) - Faculdade de Medicina da Universidade de São Paulo, São Paulo. 
HOFFBRNAD, A.V.; PETTIT, J.E.; MOSS, P.A.H. Fundamentos em hematologia. 4. ed. Porto Alegre: Artmed, 2004.

INOUE, H.; OSHIMA, H.; MATSUZAKI, K.; KUMAGAI, N. Application for regenerative medicine of epithelial cell culture-vistas of cultured epithelium. Congenit. Anom., v. 46, n. 3, 2006.

INTERNATIONAL ATOMIC ENERGY AGENCY. Gamma irradiators for irradiations processing. Viena, Austria, 2005

INTERNATIONAL ATOMIC ENERGY AGENCY. Radiation biology: a handbook for teachers and students. Viena, Austria, 2010.

ITALIANO, J. E.; SHIVDASANI, R.A. Megakaryocytes and beyond: the birth of platelets. J. Tromb. Haemost., v.1, n. 1, p. 1174-1182, 2003.

JOHANSSON, L.; KLINTH, J.; HOLMQVIST, O.; OHLSON, S. Platelet lysate: a replacement for fetal bovine serum in animal cell culture? Cytotechnology, v. 42, n. 2, p. 67-74, 2003.

JUNQUEIRA, L.C.; CARNEIRO, J. Histologia Básica. 10 ed. Rio de Janeiro: Guanabara Koogan, 2004.

KING, M.S; REED, G. L. Development of platelet secretory granules. Semin. Cell Dev. Biol., v. 13, n. 4, p. 293-302, 2002.

KRASNA, M.; DOMANOVIC, D.; TOMSIC, A.; SVAJGER, U.; JERAS, M. platelet gel stimulates proliferation of human dermal fibroblasts in vitro. Acta.

Dermatoven. APA, v. 16, n. 3, p. 105-110, 2007.

KURITA, M.; AIBA-KOJIMA, E.; SHIGEURA, T.; MATSUMOTO, D.; SUGA, H.; INOIE, K.; ETO, H.; KATO, H.; AOI, N.; YOSHIMURA, K. Differential effects of three preparations of human serum on expansion of various types of human cells.

Plast. Reconst. Surg., v. 122, n. 2, p. 438-448, 2008.

LARA, P.C.; RUSSEL, N.S.; SMOLDERS, I.J.H.; BARTELINK, H.; BEGG, A.C.; COCO-MARTIN, J.M. Radiation-induced differentiation of human skin fibroblasts: relationship with the survival and collagen production. Int. J. Radiat. Biol., v. 70, n. 6, p. 683-692, 1996.

LIMAT, A.; HUNZIKER, T.; COLETTE, B.; BAYREUTHER, K. NOSER, F. Postmitotic human fibroblast dermal fibroblasts efficiently support the growth of human follicular keratinocytes. J. Invest. Dermatol., v. 92, n. 5, p. 758-762, 1989.

LORENZI, T.F. Manual de hematologia propedêutica e clínica. 4. ed. Rio de Janeiro: Guanabara Koogan, 2006.

MAAS-SZABOWSKI, N.; FUSENIG, N.E. Interleukin-1-induced growth factor expression in postmitotic and resting fibroblasts. J. Invest. Dermatol., n. 107, n. 6, p. 849-855, 1996. 
MAAS-SZABOWSKI, N.; SHIMOTOYODONE, A.; FUSENIG, N.E. Keratinocyte growth regulation in fibroblast cocultures via a double paracrine mechanism. $J$. Cell Sci., v. 112, n. 12, p. 1843-1853, 1999.

MAAS-SZABOWSKI, N.; STARK, H.J.; FUSENIG, N.E. Cell interaction and epithelial differentiation. In: FRESHNEY, R.I. Culture of epithelial cells. New York: Wiley-liss, 2002. Cap. 2. p. 31-63.

MAIA, L. Plasma rico em plaquetas no tratamento de tendinite em eqüinos: avaliação clínica, ultra-sonográfica e histopatológica. 2008. Dissertação (Mestrado). Universidade Federal de Viçosa, Minas Gerais

MAJERUS, P.W.; TOLLEFSEN, D.M. Coagulação sanguínea e anticoagulantes, trombolíticos e fármacos antiplaquetários. In: GOODMAN, L.S.; GILMAN, A.

Goodman \& Gilman: As bases farmacológicas da terapêutica. 11. ed. Rio de Janeiro: McGraw-Hill, 2006. p. 1321-1341.

MANNELLO, F.; TONTI, G.A. No breakthroughs for human mesenchymal and embryonic stem cell culture: conditioned medium, feeder layer or feeder-free; medium with foetal calf serum, human serum or enriched plasma; serum-free, serum replacement nonconditioned medium or ad-hoc formula? All that glitters is not gold! Stem Cells, v. 25, n. 7, p. 1603-1609, 2007.

MASSENO, A.P.B.; PORTO, C.D.; NUNES, L.C; SEQUEIRA, J.L.; ALVARENGA, M.A. Miofibroblastos: revisão da literatura. Vet. e Zootec., v. 17, n. 2, p. 177-190, 2010.

MATHOR, M.B.; Estudos da expressão gênica mediante utilização de queratinócitos humanos normais transduzidos com o gene do hormônio de crescimento humano. "Possível utilização em terapia gênica". 1994. Tese (Doutorado). Instituto de Pesquisas Energéticas e Nucleares, São Paulo

MCNICOL, A.; GERRARD, J.M.. Platelet morphology, aggregation, and secretion. Adv. Mol. Cell Biol., v.18, p.1-29, 1997.

MIRABET, V.; SOLVES, P.; MINANA, M.D.; ENCABO, A.; CARBONELLUBEROS, F.; BLANQUER, A.; ROIG, R. Human platelet enhances the proliferative activity of cultured human fibroblast-like cells from different tissues.

Cell Tissue Banking, v. 9, n. 1, p. 1-10, 2008.

NAMBA, M.; FUKUSHIMA, F.; KIMOTO, T. Effects of feeder layers made of human, mouse, hamster, and rat cells on the cloning efficiency of transformed human cells. In Vitro, v.18, n. 5, p. 469-475, 1982.

NOLTE, S.V.; XU, W.; RENNEKAMPFF, H.O.; RODEMANN, H.P. Diversity of fibroblast - review on implications for skin tissue engineering. Cells Tissues Organs, v. 187, n. 3, p. 165-176, 2008.

OKUNO, EMIKO. Radiação: efeitos, riscos e benefícios. São Paulo: Harbra, 1998. 
PARKINSON, E.K.; YEUDALL, W.A. The epidermis. In: FRESHNEY, R.I. Culture of epithelial cells. New York: Wiley-liss, 2002. Cap. 3. p. 65-94.

PEREIRA, M.G. Anticoagulantes, antiagregantes, plaquetas e trombóticos. In: SILVA, P. Farmacologia. 6. ed. Rio de Janeiro: Guanabara Koogan, 2002. p. 604-613.

PEYREFITTE, G. Biologia da pele. In: PEYREFITE, G.; MARTINI, M.C.; CHIVOT, M. Cosmetologia, biologia geral e biologia da pele. São Paulo: Andrei, 1998. Parte 3. p. 329-478.

PRESLAND, R.B.; JUREVIC, R.J. Making sense of the epithelial barrier: what molecular biology and genetics us about the functions of oral mucosal and epidermal tissues. J. Dent. Educ., v.66, n. 4, p. 564-574, 2002.

RABENSTEIN, D.L. Heparin and heparan sulfate: structure and function. Nat. Prod. Rep., v. 19, n. 3, p. 312-331, 2002.

RANG, H.P.; DALE, M.M.; RITTER, J.M.; MOORE, P.K. Farmacologia. 5. ed. Rio de Janeiro: Elsevier, 2004.

RENDU, F.; BROHARD-BOHN, B. The platelet release reaction: granules constituents, secretion and functions. Platelets, v. 12, p. 261-273, 2001

RHEINWALD, J.G. Methods for clonal growth and serial cultivation of human normal epidermal keratinocytes and mesothelial cells. In: BARSEGA, R. (Ed.). Cell growth and division: a pratical approach. Oxford.: Oxford University Press, 1989. Cap.5. p. 81-89.

RHEINWALD, J.G.; GREEN, H. Serial cultivation of human epidermal keratinizing colonies from single cells. Cells., v. 6 n. 3, p. 331-334, 1975.

RODEMANN, H.P.; BAYREUTHER, K.; FRANCZ, P.I.; DITTMANN, K.; ALBIEZ, $M$. Selective enrichment and biochemical characterization of seven human skin fibroblasts cell types in vitro. Exp. Cell Res., v. 180, n. 1, p. 84-93, 1989.

ROSS, R.; GLOMSET, J.; KARIYA, B.; HAKER, L. A platelet-dependet serum factor that stimulates the proliferation of arterial smooth muscle cells in vitro. Proc. Nat. Acad. Sci. USA, v. 71, n. 4, p. 1207-1210, 1974.

SAMPAIO, S.A.P.; RIVITTI, E.A. Dermatologia. 3. ed. São Paulo: Artes Médicas, 2007.

SCHALLMOSER, K.; BARTMANN, C.; ROHDE, E.; REINISCH, A., KASHOFER, K.; STADELMEYER, E.; DREXLER, C.; LANZER, G.; LINKESCH, W.; STRUNK, D. Human platelet lysate can replace fetal bovine serum for clinical-scale expansion of functional mesenchymal stromal cells. Transfusion, v.47, n. 8, p. 1436-1446, 2007. 
SCHWARTZ-ARAD, D.; LEVIN, L.; ABA, M. The use of platelet rich plasma (PRP) and platelet rich fibrin (PRP) extracts in dental implantology and oral surgery.

Refuat Hapeh Vehashinam, v. 24, n. 1, p. 51-55, 2007.

SENEGAGLIA, A.C.; REBELATTO, C.L.K.; SISS, P.H.; BROFMAN, P.R.S. Expansão de células tronco da medula óssea e do sangue de cordão umbilical humano. Rev. Bras. Hemoter., v. 31, p. 9-14, 2009. Suplemento 1.

SILVERMAN, G.J. Sterilization and preservation by ionizing irradiation. In: BLOCK, S.S. Disinfection, sterilization and preservation, 4. ed. Malvea: Lea \& Febiger, 1991, p.566-579.

SORREL, J.M.; CAPLAN, A.I. Fibroblast heterogeneity: more than skin deep. J. Cell. Sci., v. 117, n. 5, p. 667-675, 2004.

SOUZA, M.H.L.; ELIAS, D.O. Fundamentos da Circulação Extracorpórea. 2. ed. Rio de Janeiro: Centro Editorial Alfa Rio, 2006.

STOKER, M.G.P.; SUSSMAN, M. Studies on the action of feeder layers in cell culture. Exp. Cell Res., v. 38, p. 645-653, 1965.

SUN, T.; MCMINN, P.; HOLCOMBE, M.; SMALLWOOD, R.; MACNEIL, S. Agent based modelling helps in understanding the rules by which fibroblasts support keratinocyte colony formation. PIoS ONE, v. 3, n. 5, p. 1-17, 2008.

SUN,T.; HIGHAM, M.; LAYTON, C.; HAYCOCK, J.; SHORT, R.; MACNEIL, S. Developments in xenobiotic-free culture of human keratinocytes for clinical use. Wound Repair Regen., v.12, n. 6, p. 626-634, 2004.

TENCHINI, M.C.; RANZATI, C.; MALCOVATI, M. Culture techniques for human keratinocytes. Burns, v. 18, n. 1, p. s11-s15, 1992. Suplemento 1.

TODARO, G.J.; GREEN, H. Quantitative studies of the growth of mouse embryo cells in culture and their development into established lines. J. Cell Biol., v. 17, p. 299-313, 1963.

WAELTI, E.R.; INAEBNIT, S.P.; RAST, H.P.; HUNZIKER, T.; LIMAT, A.; BRAATHEN, L.R., WIESMANN, U. Co-culture of human keratinocytes on postmitotic human dermal fibroblast feeder cells: production of large amounts of interleukin 6. J. Invest. Dermatol., v. 98, n. 5, p. 805-808, 1992.

WONG, T.; MCGRATH, J.A.; NAVSARIA, H. The role of fibroblasts in tissue engineering and regeneration. Br. J. Dermatol., v. 156, p. 1149-1155, 2007.

XIAO, S.; ZHU, S.; MA, B.; YANG, J. WANG, G. A new sytem for cultivation of human keratinocytes on acellular dermal matrix substitute with the use of human fibroblast feeder layer. Cells Tissues Organs, v. 187, n. 2, p. 123-130, 2008.

YOUNG, B.; LOWE, J.S.; STEVENS, A.; HEATH, J.W. Wheater histologia funcional: texto e atlas em cores. Rio de Janeiro: Elsevier, 2007. 
ZAGO, M.A.; FALCÃO, R.P.; PASQUERE, R. PASQUINI, R. Hematologia: fundamentos e prática. 1. rev ed. São Paulo: Atheneu, 2004.

ZARBOCK, A.; POLANOWSKA-GRABOWSKA, R. K.; LEY, K. Platelet-neutrophilinteractions: linking hemostasis and inflammation. Blood Rev., v. 21, n. 2, p. 99$111,2007$. 